\title{
Extra Alliteration on Stressed Syllables in Old English Poetry: Types, Uses, and Evolution
}

\section{Introduction}

The Old English poetic line consists of two verses, each a metrical unit. Each normal verse contains two main stresses. The structure of both verse and line are made audible by alliteration. The first stress of each verse-being primary in the verse-always carries alliteration, thereby marking verse boundaries and tying the two verses into a single structure. Alliteration on the second stress of the first verse (the a-verse) is frequent, but not required by the structure of the line; the metrical shape of the verse governs the majority of its use. The second stress of the bverse, being secondary both in its line and verse position does not alliterate. This form arises out of both word and sentence stress in the Old English language. Word stress normally falls on the first, or stem, syllable, of a word so that the rhythmical structure of an un-prefixed, inflected Old English noun, adjective or verb is trochaic. ${ }^{1}$ That the finite verb of the clause, unstressed when placed before the first metrical stress, most commonly occupies the final position of the alliterative line when stressed is indicative of the relative lightness of this position. ${ }^{2}$ Two alliterative patterns for the line accordingly predominate: $\mathbf{A x} \mathbf{A x}$ and $\mathbf{A A} \mathbf{A x}$. A third pattern occurs where unstressed parts of speech cluster at the start of a clause and the first stress is omitted: $\mathbf{- A} \mathbf{A x} .^{3}$

Alliteration, however, occurs more pervasively on stressed syllables than is generated by these basic rules. Such additional alliteration is the subject of this piece. It comes in at least two different general forms. There is, first, supererogatory alliteration, that is, extra alliteration where the addition is neither required by the alliterative rules, nor forbidden by them (in so far as we understand these). This may occur either within the line, or across lines. At least five main types present themselves:

a. Double alliteration in a-verses of metrical types where the second alliteration is not required by metre

b. Consonant cluster alliteration across the a-verse or the line (other than on the clusters $s c$-, $s p$ - and st-, which, by rule, alliterate only with themselves)

c. Continued alliteration of the same sound across immediately proximate lines (involving between four and six consecutive alliterations on the same sound in two lines, or between six and nine in three lines)

d. Interlaced alliteration, or the patterned alternation of alliterating sounds across several lines of a poem.

e. Enjambed or 'strong-linked' alliteration (where the final non-alliterating stress of a line alliterates with the primary alliterating stress of the following line).

\footnotetext{
${ }^{1}$ Compounds follow a similar pattern, the first element bearing heavier stress than the second.

${ }^{2}$ In the first fifty two lines of Beowulf, for example, finite verbs occupy the final position of the line on twenty-two occasions, and the second position of the a-verse (the next weakest position) in six verses (12a, 15a, 24a, 26a, 30a, 32a). Only four occupy the first position (6a, 8a, 34a, 49a); two alliterate as the sole stress of the a-verse (28a, 47a); six are unstressed in a dip. The final position of these lines is occupied nine times by the second element of a compound, and seven times by a non-finite verb.

${ }^{3}$ Where $\mathbf{A}$ indicates a stressed and alliterating stem syllable, $\mathbf{x}$ an unstressed stem syllable, and - a verse position occupied only by unstressed syllables.
} 
'Strong-linked' is a term from Orchard's stimulating discussion of artful alliteration in the poetry. ${ }^{4}$ The following patterns which he includes as being (at least potentially) rhetorical and which all involve the final, non-alliterating position of the line in more distant alliteration are here excluded from consideration:

1. 'Weak-linked' alliteration (where the final non-alliterating stress of a line alliterates with the second stress of a following a-verse with single alliteration)

2. 'End-linked' alliteration (where the final non-alliterating stress of a line alliterates with the final non-alliterating stress of the next line)

3. 'Back-linked' alliteration (where the final non-alliterating stress of a line alliterates with the alliterating stresses of the previous line)

Two further types of enhanced alliteration within the line are difficult in one way or another and so are also excluded from this discussion:

1. Vocalic alliteration across the line on the same vowel. Vowel alliteration in the poetry binds verses together into lines as consonant alliteration does, but repetition of the same vowel is not required. ${ }^{5}$ Indeed, exact phonetic repetition across three stresses of a line, with both quality and quantity maintained, is extremely rare in Old English poetry, ${ }^{6}$ so

\footnotetext{
${ }^{4}$ A. Orchard, ‘Artful Alliteration in Old English Song and Story’, Anglia 113 (1995), 429-63. Orchard is particularly concerned with the relationship between such alliterative features in Old English and similar features in other literatures known (or perhaps known) to the AngloSaxons.

${ }^{5}$ There are different views of the nature of vocalic alliteration: that it is consonant alliteration of word-initial glottal stops which are not represented in the orthography; that it is the product of a perception of the general likeness of vowels; that it is a kind of 'negative' alliteration, by which the patterned absence of expected consonants satisfied the rules; or that it is a traditional licence. See E. Classen, Vowel Alliteration in the Old Germanic Languages (Manchester, 1913), P. Salmon, 'Anomalous Alliteration in Germanic Verse', Neophil 42 (1958), 223-41, and S. Suzuki, The Metrical Organization of 'Beowulf': Prototype and Isomorphism, Trends in Linguistics, Studies and Monographs 95 (Berlin, 1996), section 6.4, pp. 307-12.

${ }^{6}$ Only once certainly in the entire corpus. Beowulf 835 earm ond eaxle, per wees eal geador presumably had $c e l$ retracted rather than broken to eal in the poem's original dialect (so, also, GenA 1191, PPs 131.8.2). GenA 1547 Olla, Olliua, Olliuani is unlikely to be a complete line of verse and may have originated as a marginal gloss. Dan 78 qualifies if the vowel opening the proper name Ebreum is long (the vowels opening those in PPs 82.6.3a probably contrast in quantity with 82.6.3b Agareni). ChristA 311 shows repetition of $\bar{a}$ across the line only if Cook's emendation of MS elda is correct. Only Men 102 cenigne cer cefre bringan certainly shows this feature. By contrast, in a much smaller body of examples of vocalic alliteration in some Middle English alliterative poems, it appears quite commonly: see J. Lawrence, Chapters on Alliterative Verse (London, 1893), pp. 56-113. Ornamental use of it is also occasionally found in Ælfrician rhythmical prose (e.g. the opening alliterative line of 'St Edmund, King and Martyr: Eadmund se eadiga Eastengla cyning, with onomastic word play and ensuing transverse alliteration, which introduces the king, and marks the transition between nonrhythmical and rhythmical prose sections).
} 
that it is possible that vocalic contrast rather than sameness was sought for. ${ }^{7}$ If so, this type of alliteration is aesthetically different from consonant alliteration. ${ }^{8}$

2. Consonant alliteration across the line where the consonant in each case is followed by the same vowel. If vowel alliteration on the same vowel is problematic in nature, then it seems to follow that word-internal vocalic repetition must also be so. ${ }^{9}$

Secondly, there is licentious alliteration, that is, alliteration which departs from the rules of the structure by drawing the fourth, final stress of the line into alliteration within its own line, from which it is normatively absent. Supererogatory alliteration, because it is unproblematic by the rules, constitutes (where it is deemed to have rhetorical significance) a kind of easy ornament. Licentious alliteration, on the other hand, appears either to breach the rules as described, or to play with them dangerously. Transgressing the norm, or moving beyond the hinterland of the conventional, may signal the use of hard ornament, or perhaps a move to a new poetics, or maybe just bad poetry. At least four sub-divisions of this type are observable:

a. Crossed alliteration (where the final stress participates in secondary alliteration in the line in the pattern $\mathbf{A B} \mathbf{A B}$, and similar patterns)

b. Postponed alliteration (where the final stress alliterates instead of the first stress of the b-verse, giving the alliterative patterns AB CA and AA BA) ${ }^{10}$

c. Transverse alliteration (where the final stress alliterates with the first stress of the averse and the first stress of the b-verse participates in secondary alliteration, giving the pattern AB BA and similar)

d. Hyper-alliteration (where there is double alliteration in the b-verse, giving the alliterative patterns AB AA and AA AA).

Each of these nine types of alliteration - double, cluster, continued, interlaced, enjambed; crossed, postponed, transverse and hyper-alliteration-is assessed below (with some attention here and there to sub-types); postponed, transverse and hyper-alliteration are grouped together in the discussion because they share the common feature of primary alliteration on the final position of the line. Appendices list all occurrences of cluster, continued, interlaced, enjambed and crossed alliteration across the surviving poetic corpus; instances of postponed, transverse and hyper-alliteration are listed in the body of the argument. The a-verses with double alliteration are too numerous to list.

\section{1: Supererogatory Alliteration}

Where extra alliteration not required by rule occurs on stressed syllables, there is a possibility that its occurrence is chance. The Old English language has a limited set of

\footnotetext{
${ }^{7}$ So asserts Salmon, 'Anomalous Alliteration', p. 223. Compare Snorri Sturluson's view in the Háttatal: 'if a vowel is the main stave, the stuðlar (the staves are called stuðlar, 'props' or 'supports') should also be vowels; and it is more beautiful if each vowel is different' (quoted from A. H. Martin, Snorri Sturluson's Háttatal: A Translation and Commentary (unpublished dissertation, North Carolina, 1974), p. 5.

${ }^{8}$ On this point, see further, below.

${ }^{9}$ But note that W. P. Lehmann, The Alliteration of Old Saxon Poetry, Norsk Tidsskrift for Sprogvidenskap Suppl. Bind III (Oslo, 1953), pp. 25-30, finds evidence of such assonance in the Heliand which he attributes to the influence of Latin rhymed poetry.

${ }^{10}$ Strictly, postponed alliteration does not involve extra alliteration, but I include its use in the b-verse because of its close relation with transverse and hyper-alliteration in breaching the rule governing the last position of the line. Postponed alliteration in the a-verse is rare, but attested (e.g. Beo 707a, 3056a).
} 
phonemes and these necessarily recur in the production of speech (or text), so that the recurrence of phonemes word initially is linguistically inevitable. Several critics have addressed the question of the probability of such chance occurrence in the poetry. Extrapolating from the distribution of the word-initial sounds of 'stressable' words in Old English prose, Ross, in an influential article, argued that chance alliteration occurs in the poetry with an overall probability of approximately one in twelve. ${ }^{11}$ Ross has been rightly criticised for drawing his conclusion about poetic practice from the evidence of the prose. ${ }^{12}$ The diction of the prose is different from that of the verse, there being a significant body of words confined to, or occurring with disproportionate frequency in, the poetry, and, conversely, another corpus of words which occurs mainly in the prose. ${ }^{13}$ His assumption that Old English lexis may straightforwardly be divided into 'stressable' words and 'unstressable' ones is also problematic, for sentence particles and proclitics are stressed in the verse when displaced from their normal syntactic position, but not otherwise. ${ }^{14}$ Hutcheson, reassessing the probability for the poetry from the evidence of the poetry (rather than the prose), concludes that Ross's figure was too conservative, the probability being by his calculation, closer to one in ten, but he too does not separate stressed words from unstressed ones because of the difficulties involved. ${ }^{15}$ Yet, chance occurrence of alliteration is more likely in unstressed positions of the line than stressed ones because many of the commonest unstressed words in Old English begin with a restricted range of word-initial sounds. ${ }^{16}$ This may readily be illustrated:

pæt wæs Ceolan sunu
$\begin{aligned} & \text { pe ðone forman man mid his francan ofsceat } \\ & \text { pe pær baldlicost on pa bricge stop. Maldon } 76 \mathrm{~b}-8^{17}\end{aligned}$

There are six alliterations on $b$ - in two and a half lines, but none of these lines formally alliterates on $b$-. Experienced listeners, sensitive to the patterned correlation of stress and alliteration, must have been able to tune out this background noise of frequent incidental

${ }^{11}$ A. S. C. Ross, 'Philological Probability Problems', Journal of the Royal Statistical Society B 12 (1950), 19-59, at 32-3.

${ }^{12}$ See B. R. Hutcheson, 'Accidental Alliteration in Old English Poetry: a Reconsideration', ELN 30 (1992), 1-10, and T. A. Bredehoft, 'Estimating Probabilities and Alliteration Frequencies in Old English Verse’, OEN 34.1 (2000), 19-23; Bredehoft appears unaware of Hutcheson's article.

${ }^{13}$ For a list of poetic words, see M. Griffith, 'Poetic Language and the Paris Psalter: the decay of the Old English tradition', ASE 20 (1991), 167-86, Appendix 1 'Poetic Words in Old English, at 183-5. For a list of prosaic words, see E. G. Stanley, 'Studies in the Prosaic Vocabulary of Old English Verse', NM 72 (1971), 385-418.

${ }^{14}$ Ross, 'Probability Problems', p. 33, footnote.

15 'In the interests of accuracy, the value of 9.7\% should replace Ross's $8.3 \%$ figure in discussions of accidental alliteration in Old English Poetry', Hutcheson, 'Accidental Alliteration', p. 9.

${ }^{16}$ With vowels (many first person pronouns, some present tense parts of 'to be', certain prepositions), with $h$ - (third person pronouns, common verbs such as habban, healdan), with $p$ - (demonstrative pronouns, certain adverbs and conjunctions), with $w$ - (parts of wesan, weorpan). Ornamental alliteration may, however, sometimes occur in unstressed contexts.

17 'He was the son of Ceola - who shot the first man with his spear who most boldly stepped onto the bridge there'. All Old English poetic quotations are, unless otherwise indicated, taken from The Anglo-Saxon Poetic Records, ed. G. P. Krapp and E. V. K. Dobbie (New York, NY, 1931-42), 6 vols (henceforward referred to as ASPR). 
alliteration. ${ }^{18}$ In the main, for this reason, such alliteration falls outside the boundaries of this analysis. ${ }^{19}$ Bredehoft's study is valuable in being the only one to date to focus solely on calculating the probability of chance alliteration in the poetry on stressed syllables, but his database is restricted to the first thousand lines of Beowulf. Further reference is made to his article in following sections. Because a feature occurs less frequently than we might expect it to do by chance, however, does not force us to conclude that, where it does occur, it necessarily cannot have literary significance. Nor, on the other hand, where a feature occurs more frequently than chance would lead us to expect and excess may suggest design, should we conclude that the instances are all necessarily purposeful. We must accept that chance played a role in the occurrence of additional alliteration, and that the likelihood of accidental alliteration must increase the greater the number of words that intervene between any two alliterating items (and hence the exclusion from this discussion of 'weak-linked', 'end-linked' and 'back-linked' alliteration). However, additional alliteration on a sound heading a stressed syllable in close proximity to syllables alliterating functionally on that sound seems unlikely to have been produced accidentally by a poet who was necessarily focussing on that alliterative sound in that particular context, or to have been ignored by audiences alert to stressed wordinitial sounds. The onus, indeed, lies on the critic to argue for the literary significance of such features, and the rhetoricity of additional alliteration may depend on a number of factors: whether a given feature is rare, whether it clusters in a particular context, whether it appears in conjunction with other stylistic features, and whether it suits the context of usage. All such factors will be considered, as appropriate, below.

Different word-initial sounds do not occur with equal frequency in the Old English poetic lexicon, so that the possibility of chance alliteration on stressed syllables is significantly less with some sounds than with others, and the possibility of poetic significance, accordingly, greater. In descending order of frequency, the alliterating sounds occur in the surviving poetic corpus of poems of fifty lines or more at the following rates (with, in brackets, the highest and lowest rates of occurrence in the poems longer than 300 lines, and the rate of occurrence in Beowulf):

\section{Table One Percentage of Lines Alliterating on each Permitted Sound}

$\begin{array}{ll}\text { Vowels 18.4\%, 5208 ll. } & \text { (Met 28.7\%, Beo 16.0\%, El 13.4\%) } \\ \text { w- 12.2\%, 3459 ll. } & \text { (GenB 15.2\%, Beo 11.1\%, JDay II 8.5\%) } \\ \text { h- 10.3\%, 2899 ll. } & \text { (GenB 19.9\%, Beo 13.2\%, MSol 5.1\%) } \\ \text { s- 10.0\%, 2824 ll. } & \text { (ChristA 14.1\%, Beo 10.7\%, Mald 4\%) } \\ \text { f- 8.9\%, 2515 ll. } & \text { (Mald 14.8\%, Beo 9.6\%, GenB 5.2\%) } \\ \text { m- 7.3\%, 2069 ll. } & \text { (Ex 10.8\%, Beo 7.4\%, Mald 4.0\%) } \\ \text { g- 6.0\%, 1704 ll. } & \text { (GuthA 10.1\%, Beo 9.1\%, JDay II 2.3\%) } \\ \text { b- 5.3\%, 1493 ll. } & \text { (Mald 12.6\%, Beo 7.1\%, Met 2.6\%) } \\ \text { l- 5.2\%, 1459 ll. } & \text { (GenB 9.7\%, Beo 4.7\%, Sat 2.6\%) } \\ \text { d- 3.9\%, 1111 ll. } & \text { (Sat 6.3\%, Beo 2.9\%, Mald 1.5\%) } \\ \text { c- 2.5\%, 717 ll. } & \text { (El 5.4\%, Beo 1.1\%, GenB 0.3\%) } \\ \text { p- 2.4\%, 671 ll. } & \text { (Jul 4.5\%, Beo 2.3\%, Ex 1.2\%) } \\ \text { r- 1.8\%, 511 ll. } & \text { (El 3.5\%, Beo 1.3\%, Sat 0.2\%) }\end{array}$

${ }^{18}$ C. B. Kendall, The Metrical Grammar of Beowulf, CSASE 5 (Cambridge, 1991), p. 222, defines 'incidental alliteration' as 'non-functional alliteration on [an undisplaced] sentence particle or proclitic'.

${ }^{19}$ But some attention is paid to the alliteration of undisplaced finite verbs whose stress status remains uncertain. 


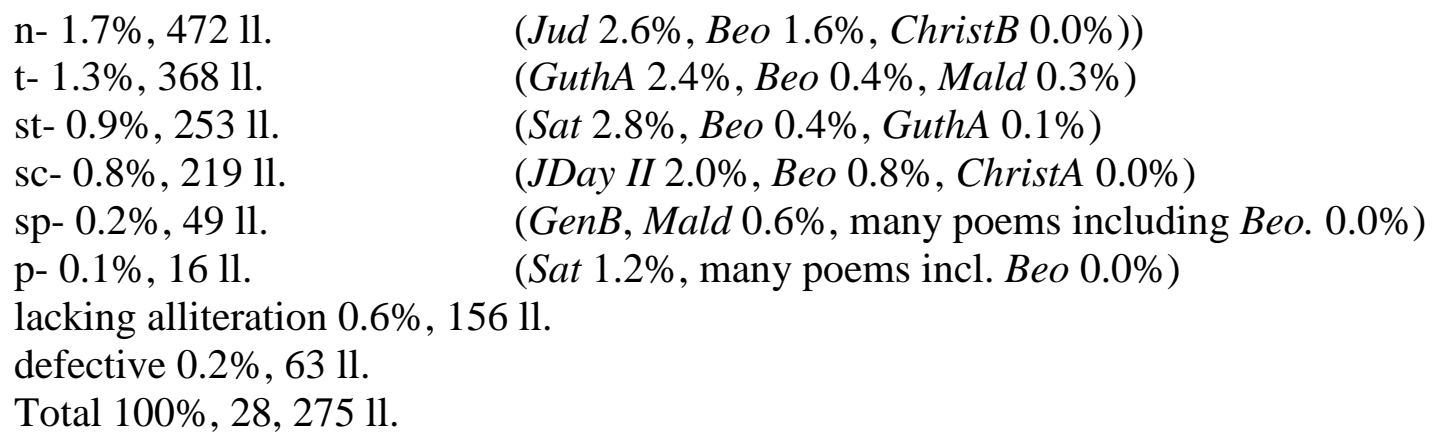

Several points of interest emerge. First, the distribution of word-initial sounds in alliterating positions is not the same as that in unstressed ones: $p$-, for example, which proliferates in unstressed positions, alliterates in only $2.4 \%$ of these 28,275 lines. The failure by Ross and Hutcheson to distinguish between stressed and unstressed words, albeit an understandable one, is hereby shown to be one damaging to their conclusions. Secondly, beneath the overall picture, the practice of the poets can be seen to vary quite considerably: whilst Beowulf is close to the mean, Genesis B and The Battle of Maldon show extremes of use more often than the other poems, reflecting, in part, the Old Saxon origin of the first and the late date of the second. ${ }^{20}$ Most significant, however, is the fact that some few sounds predominate in alliteration where others are uncommon or rare. Half of the lines of the corpus alliterate on just four sounds (vowels, w-, $h-, s_{-}$): extra alliteration on these sounds was easier to produce (and likelier to occur by chance) than on other sounds. Conversely, twelve word-initial sounds ( $b-, l-, d-, c-$, $p-, r-, n-, t-, s t-, s c-, s p-, p-)$, which together form more than half of the available alliterating sounds, yet account in total for only a quarter of the lines of this corpus. Functional alliteration on these was more difficult to achieve (because of the comparatively limited opportunities offered by the lexicon) and instances of added alliteration on these sounds are, accordingly, much likelier to be the product of artistry and to have been noticed by the audience.

\section{a. i Double alliteration in the a-verse}

Double alliteration, although not required by the structure of the line is, nonetheless, required in certain metrical types. Bliss demonstrates that in almost all types where the first foot is shorter than the second one, ${ }^{21}$ or where there is secondary stress in addition to the normal two stresses, ${ }^{22}$ double alliteration is compulsory or quasi-compulsory in Beowulf. ${ }^{23}$ Where both constraints are in operation, double alliteration occurs without exception. ${ }^{24}$ Over eleven hundred a-verses in Beowulf are of these types. Double alliteration, however, also occurs nearly four hundred times in a-verses in Beowulf of other metrical types where the first stressed word or word group is the same length as, or longer than, the second and where there is no secondary

\footnotetext{
${ }^{20}$ But see, also, below, passim, on the alliterative features of The Battle of Maldon: theme and style are certainly also relevant.

${ }^{21} 1 \mathrm{~A} 1 \mathrm{a}$, e.g. 13a geong in geardum, $1 \mathrm{~A} * 1 \mathrm{a}$, e.g. 14a folce to frofre, and 1D*1, e.g. 689a eorles andwlitan, excluding only type 1D1, mainly in verses with proper names, e.g. 268a sunu Healfdenes.

22 2A2, e.g. 131a polode ðryðswyð, 2A3, e.g. 27a felahror feran, 2A4, e.g. 1881a guðrinc goldwlanc, 2E2, e.g. 477a wigheap gewanod. In 3E2 (e.g. 644a sigefolca sweg) and 3E*2 (e.g. 476a fcerniða gefremed), double alliteration predominates, but exceptions are more numerous. ${ }^{23}$ See A. J. Bliss, The Metre of Beowulf, rev. ed. (Oxford, 1967), pp. 26 and 36-8, and his Appendix C, Table I, pp. 122-3.

${ }^{24}$ In 1A2, e.g. gamol ond guðreouw, 1A*2-4, e.g. $1 \mathrm{~A} * 2$ at 277a hynðu ond hrafyl, 1D2-6, e.g. $1 \mathrm{D} 2$ at 21 a fromum feohgiftum, $1 \mathrm{D} * 2-6$, e.g. $1 \mathrm{D} * 3$ at 103a mære mearcstapa.
} 
stress. ${ }^{25}$ Occasionally too it appears in self-alliterating compounds in light verses (types a2, d2$5,1 A 1$, and 2A1). In neither case is there any apparent metrical reason for the extra alliteration. Metrical-grammar, however, explains some of these: in some forty such a-verses, for example, the second stressed word begins with a prefix and this imposes an alliterative requirement on the stem syllable (e.g. in verses such as 79a se pe his wordes geweald and 362a ofer geofenes begang). ${ }^{26}$ In more than eighty of these verses, the second alliterating word is poetic, or poetic in sense, or occurs with disproportionate frequency in verse, or is hapax legomenon, and, poetic words in alliterative poetry are particularly linked with the alliterating positions of the line, so that register rather than metre or metrical-grammar may here be the determining factor. ${ }^{27}$ In some few of these verses, the poet deploys alliterating phrases of a general utility that are also a part of his poetic diction (e.g. descriptions of the physical world) ${ }^{28}$ However, in very many cases no such explanations hold, and some which are particular to the poem's story must have been composed or adapted by the poet himself (e.g. 384a wið Grendles gryre, 403a under Heorotes hrof, 407a Wces pu Hroðgar, hal, 1091a Hengestes heap, etc.). There are at least 250 a-verses in the poem, then, where it seems the poet has added the alliteration by his own design. In the main, these do not occur in clusters or in combination with other non-functional alliterative features; they are not associated with any particular theme, or character, or genre of utterance; they do not appear, at least not self-evidently, to serve any local stylistic or rhetorical purpose. The rule of line structure appears from the evidence of Beowulf to be the general motivation for their particular occurrence, the poet seemingly experiencing a frequent need for its explicit re-affirmation.

Elsewhere in the corpus, groupings of this extra alliteration may be rhetorically motivated, but the boundary between style and rule is not an easy one to draw with a feature so closely tied into the metrical rules. Of all the longer poems, The Phoenix shows the most liberal use of double alliteration in the a-verse, ${ }^{29}$ and one reason for this is the frequency of its occurrence in metrical types where it is not required by the metre. Part of the description of the earthly paradise is instructive (lines 11-20):

${ }^{25}$ In type $2 \mathrm{~A} 1$ at the rate of $34 \%, 2 \mathrm{~B}$ at $44 \%, 3 \mathrm{~B}$ at $35 \%, 3 \mathrm{~B} *$ at $24 \%, 2 \mathrm{C}$ at $46 \%, 2 \mathrm{E} 1$ at $25 \%$, $3 \mathrm{E} 1$ at $73 \%$.

${ }^{26}$ See Kendall, Metrical Grammar, pp. 100-10. The relevant a-verses are in lines 79, 362, 455, 476, 477, 548, 633, 654, 658, 667, 756, 760, 775, 800, 877, 911, 1077, 1360, 1484, 1498, 1681, 1723, 2045, 2150, 2208, 2259, 2287, 2312, 2353 2441, 2467, 2505, 2508, 2566, 2633, 2748, 2767, 2792, 2879. Metrical-grammar also may account for the extra alliteration in a few other of these a-verses (with references to Kendall in brackets): 504 (p. 130), 511 (pp. 110-15), 642 (pp. 110-15), 1063 (pp. 110-15), 1763 (pp. 110-15), 1864 (p. 121), 2105 (pp. 110-15), 2472 (pp. 110-15).

${ }^{27}$ See the a-verses of lines 6, 20, 35, 60, 91, 124, 130, 167, 181, 182, 185, 188, 259, 264, 267, 352, 362, 384, 414, 424, 478, 527, 548, 573, 637, 756, 760, 765, 784, 788, 810, 836, 849, 850, 917, 924, 980, 1001, 1034, 1077, 1148, 1185, 1210, 1228, 1238, 1239, 1254, 1265, 1280, 1281, 1299, 1311, 1329, 1376, 1379, 1393, 1401, 1423, 1478, 1487, 1542, 1547, 1555, 1672, 1717 , 1726, 1763, 2128, 2133, 2140, 2160, 2188, 2220, 2342, 2352, 2394, 2505, 2535, 2622, 2671, $2695,2792,2988,3007,3119,3154,3176$. In four, the poetic word is prefixed (362, 548, 760, 1077), so that either metrical-grammar or register may account for the extra alliteration.

${ }^{28}$ See (of the natural world) 507a ofer sidne sce, 572a windige weallas, 840a, 1704a geond widwegas, 1411a neowle næessas, 1693a purh wœeteres wylm, 1950a ofer fealone flod; (of the human world) 983a ofer heanne hrof, 997 wæes pæet beorhte bold, 1199a to pære byrhtan byrig. ${ }^{29}$ In 426 lines out of 677, or 62.9\%. Despite this fact, the poem's modern editor characterises its style as ‘simple, fairly plain’: see The Phoenix, ed. N. F. Blake (Manchester, 1964), p. 35. 
pær bið oft open eadgum togeanes

onhliden hleopra wyn, heofonrices duru.

bæt is wynsum wong, wealdes grene,

rume under roderum. Ne mæg pær ren ne snaw,

15

ne forstes fnæst, ne fyres blæst,

ne hægles hryre, ne hrimes dryre,

ne sunnan hætu, ne sincaldu,

ne wearm weder, ne winterscur

wihte gewyrdan, ac se wong seomað

20

eadig ond onsund. ${ }^{30}$

Here metre demands double alliteration in verses 12a, 14a, 19a, and 20a, where the first foot is shorter than the second. These four, if they were the only such verses, would give the passage a normal rate of occurrence of the feature. But, in addition, there is extra alliteration in verses 11a (2C2), 13a (3B1), 15a (3B1), 16a (3B1), and 18a (2C2), leaving only a single a-verse without it (17a). This supererogation, unlike its counterparts in Beowulf, occurs in combination with other stylistic features suggestive of deliberate artistry: continued alliteration (18-19), touches of cluster alliteration (12a onhliden hleopra, 15 hryre: hrimes), marked syntactic parallelism (14b-18b), pleonastic semantic oppositions (14b rain and snow, 15 frost and fire, 17 heat and cold, 18 warm weather and winter shower) — and, unusually, rhyme (15-16). The poet describes an ideal place for an ideal bird and a style more embellished than usual conveys this well. Description elsewhere in the corpus also appears sometimes to stimulate extra double alliteration. ${ }^{31}$ Nevertheless, although the style seems selected for a purpose, its alliterative supererogation is not a simple product of the poet's choice.

30 'There heaven kingdom's portal is often open and the delightfulness of singing voices revealed to the blessed. It is a delightsome plateau. There the green woodlands, spacious beneath the skies, not rain nor snow, nor breath of frost nor scorch of fire, not falling of hail nor drizzle of rime, nor heat of the sun nor incessant cold, nor torrid weather nor wintry shower may spoil a whit, but the plateau remains perfect and unmarred.' The translation is taken from S. A. J. Bradley, Anglo-Saxon Poetry (London, 1982), p. 286.

${ }^{31}$ Compare the similar rhyming description of Paradise by negatives in GuthB 827-30. Lucas also points to Exodus 98-134 and 447-87 as examples of what he calls 'alliterative pyrotechnics' with very high levels of double alliteration; see Exodus, ed. P. J. Lucas, rev. ed. (Exeter, 1994), pp. 42-3. 
The corpus of traditional or 'classical' verse (outside of The Riming Poem) ${ }^{32}$ shows rhyme joining the two verses of the line where the a-verses are not of metrical types where double alliteration is compulsory or quasi-compulsory as follows: ${ }^{33}$

$\begin{array}{lll}\text { 2A1 } & \text { And } 867 & \text { brehtmum bliðe beorhte ond liðe } \\ & \text { And } 1631 & \text { wuldres wedde witum aspedde } \\ \text { El } 1239 & \text { nihtes nearwe. Nysse ic gearwe } \\ & \text { Wid } 139 & \text { gydda gleawne geoful unhneawne } \\ & \text { Rid } 38.4 & \text { scire sceotan, on gesceap peotan } \\ & \text { And } 1404 & \text { Sint me leoðu tolocen, lic sare tobrocen } \\ \text { 2B } & \text { El } 1236 & \text { Dus ic frod ond fus purh pæt fæcne hus } \\ & \text { And } 1380 & \text { in wræc wunne, wuldres blunne } \\ \text { 2C } & \text { El } 1242 & \text { wisdom onwreah. Ic wæs weorcum fah }{ }^{35} \\ \text { 2E1 } & \text { GenA } 1922 & \text { Seo wæs wætrum weaht ond wæstmum peaht }\end{array}$

32 'Traditional' here denotes the poems of ASPR I-IV, 'non-traditional' ASPR V-VI together with Instructions for Christians. For the text of Instructions for Christians, see J. L. Rosier, 'Instructions for Christians, a Poem in Old English', Anglia 82 (1964), 4-22. Some short poems and fragments in ASPR VI are, or appear to be, traditional (e.g. Wald, Winfrid, Cad, BDS, LRid, RuthCr, FrCask) or nearly traditional (Brun); none features verse-end rhyme. The broad distinction is long-standing and characterised usually as a contrast of early, metrically normal poetry and late poetry with metrical abnormalities. Verse-end rhyme is exceptionally rare in PPs (only at 118.79.1, although the near rhyme of syllables with vowels of different quantity occurs at 88.9.2, 113.3.1, 117.12.3, 138.9.3, and rhyme within verses at 56.6.2b, 64.11.4b, 68.32.1a, 68.32.1a, 76.2.3b, 77.20.7b, 118.134.2b, 122.1.2b). JDay II, DAlf and Mald are notably looser in their rhyming.

${ }^{33}$ Where 'rhyme' is defined as 'the relation between stressed syllables that begin differently and end alike'; see W. Harmon, 'Rhyme in English Verse: History, Structures, Functions', SP 84 (1987), 365-93, at 369. Accordingly, verse-final word repetition (e.g. El 171, Wand 108-9, Rid 65.5), monosyllables 'rhyming' with disyllables (e.g. ChristC 1320 pwean: prean), rhyme confined to inflected syllables or to syllables bearing secondary or tertiary stress (e.g. Ex 231) are all here excluded. Excluded too is the rhyme or near rhyme of syllables bearing different degrees of stress (e.g. Sat 117, And 888, El 115, Phoen 54, Beo 726, 2258, Jud 231, Caed 7), of syllables with vowels of different quantity (e.g. And 216, ChristB 592, Fort 68), or quality (e.g. Mald 47), or with consonants of different length (e.g. Beo 3029), and of syllables where rhyming stems are followed by different inflections (e.g. And 31). Latin rhymes (e.g. Rid 90) are here ignored. All these features (apart from the last) occur sporadically, sometimes in combination with true rhyme, and may be artistic, but their treatment by the poets differs sometimes from their handling of true rhyme, although many instances do follow the pattern outlined here. Lists of many of them, together with examples of rhyme within the verse and also across lines, may be found in F. Kluge, 'Zur Geschichte des Reimes im Altgermanischen', BGdSL9 (1884), 422-50.

${ }^{34}$ Taking the prefix un- here to be unstressed; see C. B. Kendall, 'The prefix un- and the metrical-grammar of Beowulf', ASE 10 (1982), 39-52, at 52: 'If the prefix does not alliterate, it is not stressed.'

${ }^{35}$ On Sievers's restoration of Anglian forms in a number of Cynewulf's rhymes (El 1240, 1241, 1242). see Cynewulf's 'Elene', ed. P. O. E. Gradon (London, 1966), pp. 13-14, and R. D. Fulk, A History of Old English Meter (Philadelphia, PA, 1992), pp. 362-8. Relevant here, too, may be MSol I.79 scyld (=Anglian sceld), but the dialect of the poem is uncertain. 


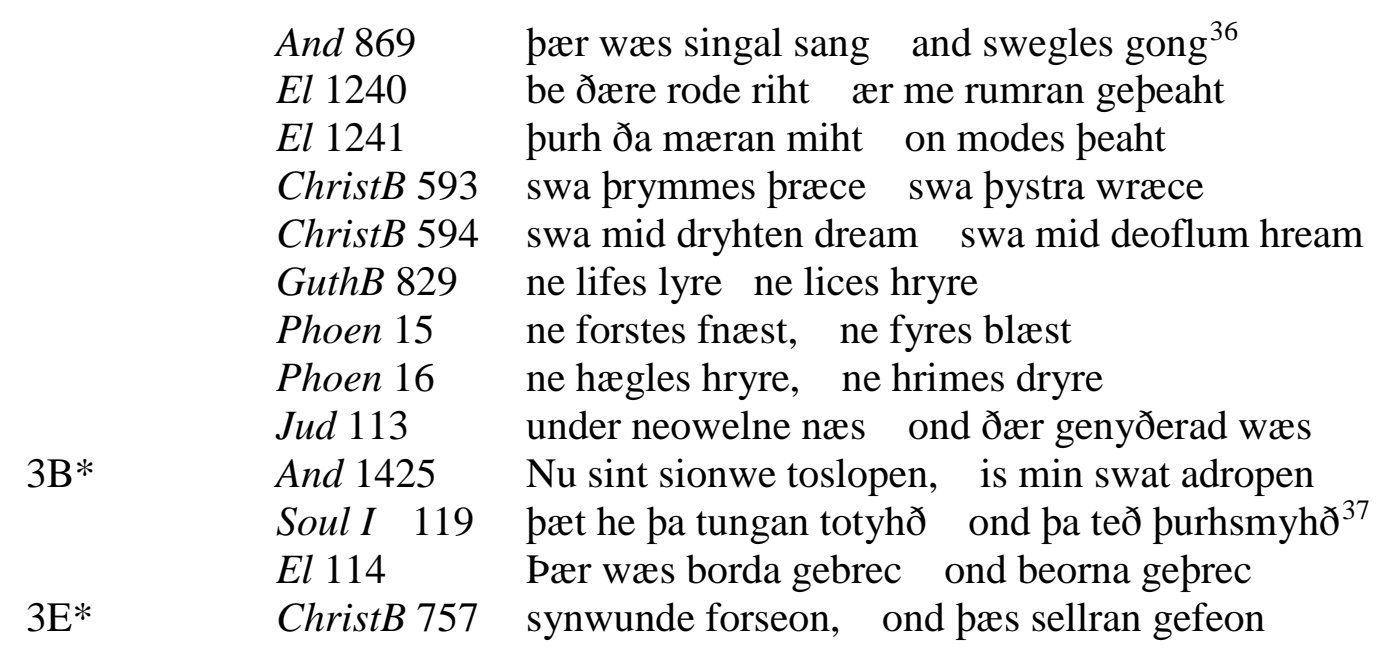

Despite the fact that these lines occur in a wide range of poems from different periods (Genesis A being relatively early, for example, beside Judith which is thought to be quite late) and composed in different dialects (Elene and Christ B by Cynewulf are agreed to be Anglian, and Judith very probably West-Saxon) their different composers have all responded to the use of true rhyme in exactly the same fashion as the poet of The Phoenix. ${ }^{38}$ All of these twenty-three a-verses contain two stresses and double alliteration. Bliss's rules of Old English metre frequently rest on the compulsory or quasi-compulsory appearance of double alliteration in particular types; by the same token, its universality here also indicates a rule, but, in this case, not one generated by the metrical type of the verse, but, rather, by the deployment of rhyme across the line. Verse-end rhyme threatens the normal structure (which prioritises the beginnings of its first and third stressed positions) by establishing a new relationship between the ends of its second and fourth positions which contrasts with the alliterative principle. Double alliteration in the a-verse gives the alliterative structure the optimal prominence in the face of the rival structure, and the surviving evidence shows this addition to be the normative response of traditional poets: the a-verse of a line with true verse-end rhymes ought to display double alliteration. ${ }^{39}$ This rule, or general shared response, is unique amongst the metrical rules governing double alliteration in the a-verse in the sense that the extra alliteration is generated by a structure which only becomes evident by the end of the line, rather than by the close of its first verse. Important too is the fact that there are no lines of verse-end rhyme in the traditional poems with a-verses that are light verses (types a, $d$ and e); the first two of these are

${ }^{36}$ On variation between $a$ and $o$ before nasals, see A. Campbell, Old English Grammar (Oxford, 1959), §130.

37 The line is repeated at Soul II 114 (with topas varying teð).

${ }^{38}$ Double alliteration occurs frequently with rhyme in the Anglo-Latin verse of Aldhelm and Æthilwald: see A. Orchard, The Poetic Art of Aldhelm, CSASE 8 (Cambridge, 1994), pp. 4954. Orchard sees this, probably correctly, as the influence of vernacular poetics on Anglo-Latin. ${ }^{39}$ In rhyming lines where the a-verse is of a metrical type in which double alliteration is required, double alliteration is (as is to be expected) general: see And 1587, El 1238, 1243, 1247 (assuming amcet: begret), 1249, 1250, ChristA 36, ChristB 757, ChristC 1496, 1646, Fort 95, Max I 52, 117, 120, 121, Rid 2.5, 40.2, 66.6, Beo 734, 1014, 3172, Jud 2 (with triple alliteration), 60 (with lengthening), 63, 115, 123, 202 (without palatal umlaut), 304. Beo 2792a has double alliteration, but the rhyming b-verse is the creation of editors. The following violate the rule: Vain 33a (with rhyme across both verse and line), Max I 79a, Jud 29a (with enjambed alliteration 28b-9 and cluster alliteration on $d r$-), with the additional assonances perhaps compensating for the lack of double alliteration. 
common a-verse types and there are more than 860 in Beowulf. In a list of twenty-three lines that were randomly selected from this corpus, we should certainly expect to find several. But rhyme across the first (and only) position of the a-verse and the final position of the line (competing against the alliteration of the first and the third) would undermine the alliterative structure even more radically than rhyme of the second and the fourth. This absence, then, also follows from the nature of the alliterative form: the a-verse of a line with true verse-end rhymes ought to contain at least two main stresses. The poets' general avoidance of verse-end rhyme displays an awareness of the risk to the system that it posed. The evidence of its use, scattered throughout the body of traditional verse, confirms this impression. The poets either responded separately, but identically, to this danger, or, as seems likely in a traditional poetics, they inherited a modus operandi for dealing with it, a method which allowed them occasionally to incorporate the ornament, whilst at the same time minimising its threat to the structure. ${ }^{40}$

The use of rhyme in the non-traditional poems reveals that these poets have forgotten, or abandoned, these older rules. ${ }^{41}$ Here there are quite numerous a-verses that are light and, by the metrical rules of Beowulf, type a:

\begin{tabular}{|c|c|}
\hline Met 11.16 & swa lange swa he wolde \\
\hline Met 20.103 & Gif bæt nære, ponne hio wære \\
\hline Met 20.195 & forðæm ðе hi habbað, pæs ðe hi nabbað \\
\hline Mald 271 & æfre embe stunde he sealde sume wunde \\
\hline DAlf 9 & sume hi man bende, sume hi man blende \\
\hline DAlf 17 & oðpæt man gerædde pæt man hine lædde \\
\hline DAlf 19 & Sona swa he lende, on scype man hine blende \\
\hline JDay II 82 & $\mathrm{Nu}$ pu scealt greotan, tearas geotan \\
\hline
\end{tabular}

Most of these also show alliterative defects. JDay II 3 lacks alliteration, Mald 271 either lacks alliteration, or shows the rare licence of st-: s- alliteration. Fulk thinks it possibly 'a liberty dictated by the rhyme'! ${ }^{42}$ JDay II 82 has postponed alliteration in the b-verse, with greotan and geotan supplying rhyme and alliteration. A further four (Met 20.195, DAlf 9, 17, MCharm 11.22) lack proper alliteration, but, quite remarkably, show repetition across the line of an unstressed particle that might possibly provide alliteration and a second stress (hi, man, me); if so, for these poets, lexical repetition and syntactic parallelism are supplanting the metricalgrammatical rules. Met 20.103 either lacks alliteration, or næere must be uncontracted to produce alliteration on ware in consecutive light verses, or there is alliteration on unstressed particles. Finally, the rhyming of verbs predominates here (in Met the rhyming of verbs of low natural stress) much more than in traditional rhyme.

\footnotetext{
${ }^{40}$ Accordingly, I disagree with Sievers when he says that 'Old English poets occasionally used rime as well as alliteration to set off their verse, although not according to any strict rules'; see E. Sievers, 'Old Germanic Metrics and Old English Metrics', Essential Articles for the Study of Old English Poetry, ed. J. B. Bessinger and S. J. Kahrl (Hamden, CT, 1968), pp. 267-88, at 287.

${ }^{41}$ With rhyme defined by the same rules as before, so that, for example, JDay II 3, 147, and $\mathrm{Pr}$ 59 , are excluded because they show rhyme on syllables bearing different degrees of stress. Note here Campbell's intuitively perceptive remark that: 'it seems likely that the tenth- and eleventhcentury poets, who preserved the old style, deliberately avoided rhyme' (The Battle of Brunanburh, ed. A. Campbell (London, 1938), p. 33).

${ }^{42}$ Fulk, Old English Meter, p. 259.
} 
In addition to the loss of the rule forbidding light verses, the rule that rhyme requires double alliteration in metrical types where it is not required by metre is also disappearing:

$\begin{array}{ll}\text { 2A } & \text { MSol I.80 } \\ & \text { MSol II.267 } \\ \text { 2B } & \text { JDay II 266 } \\ \text { 2C } & \text { DAlf 8 } \\ \text { 2E1 } & \text { Met 11.99 } \\ \text { 3B } & \text { MSol I.83 } \\ & \text { Instr 40 } \\ \text { 3E } & \text { Mald 282 }\end{array}$
flodes ferigend, folces nerigend
swiðe swingeð and his searo hringeð
ne bið pær wædl ne lyre ne deaðes gryre
sume hi man wið feo sealde, sume hreowlice acwealde
staðolfæst gereaht purh pa strongan meaht
on westenne weard, weorðmynta geard
and æfre fleon unrihte gestreon
Sibyrhtes broðor and swiðe mænig oper ${ }^{43}$

MSol remains traditional in this respect, but none of the other poems abides by the rule. JDay II 266, for example, echoes some traditional rhyming lines in sound and syntax:

GuthB 829 ne lifes lyre ne lices hryre

Phoen 16 ne hægles hryre, ne hrimes dryre

but it lacks, however, not only the double alliteration displayed in those traditional poems, but, indeed, all alliteration. DAlf 8 is similarly devoid of alliteration. Although in Mald 282 the assonance of -byrhtes and broðor may show some dim recollection of the need for double alliteration, the line remains irregular with primary alliteration apparently falling on $s-$. Along with loss of alliteration, there is also metrical oddity, especially lengthened dips (in DAlf 8a, 8b, Mald 282b, and JDay II 266). In these lines, rhyme has become the primary disciplining force of the poetic language. Even where metre requires double alliteration, rhyme, in these poems, is displacing it:
$1 \mathrm{~A}$
LEProv 3
Hat acolað, hwit asolað
1A* JDay II 6
innon bam gemonge on ænlicum wonge
? DAlf 6
Ac Godwine hine pa gelette and hine on hæft sette

DAlf 6 lacks alliteration. Its a-verse is strictly unscannable, but of a general shape (with anacrusis) that would conventionally require double alliteration. The other two show single alliteration only. ${ }^{44}$

Turning to the one Old English poem that uses true rhyme systematically, The Riming Poem, ${ }^{45}$ we find that it follows with some rigour both of the above principles, despite the considerable added difficulty the first imposed upon composition, and the fact that both,

\footnotetext{
${ }^{43}$ With syncope in broðer: oper.

${ }^{44}$ LEProv 3 is, perhaps, to be excluded as the rhyme strictly appears to be on stem vowels of different quantity. Unprefixed forms of the two verbs, however, rhyme in Rim 67, and also in The Owl and the Nightingale where the same proverb occurs (see The Owl and the Nightingale, ed. E. G. Stanley (London, 1960), p. 86, lines 1275-6). Both Rim 67a and LEProv 3b lack a metrical position if the stem vowel is short. Whether it is long or short, J. J. Campbell is not correct to assert that here we find 'good metrical and alliterative half-lines' ('Learned Rhetoric in Old English Poetry’, MP 63 (1965-6), 189-201, at 195).

45 'In all cases where the manuscript form does not indicate a good rhyme, it is possible to create one by plausible restoration of "original" forms. That would be unlikely if the poet had not in fact used good rhymes throughout', The Old English Riming Poem, ed. O. D. MacraeGibson (Cambridge, 1987), p. 2.
} 
deployed regularly, combine to produce a poem very different from other Old English poems. Double alliteration fails in just three a-verses of its eighty-seven lines, ${ }^{46}$ yet more than a quarter of these eighty-seven have a-verses of metrical types not requiring double alliteration. ${ }^{47}$ In line 79, there is neither rhyme nor double alliteration. ${ }^{48}$ In line 58 which does rhyme (mispah: genag), the a-verse steapum eatole mispah is of a metrical type requiring alliteration on both main stresses $\left(1 \mathrm{D}^{*} 6\right)$; but emendation of eatole to steaðole does not improve the sense. ${ }^{49}$ Line 77 oppcet beop pa ban an is defective; and no solution to its deficiency is obvious. ${ }^{50}$ No other a-verse apart from 77a can be interpreted as light. This near total use of double alliteration, together with the absence of verses with a single stress, is unique to this poem within the corpus, but both of these highly distinctive features of the poem are a consequence of the systematic use of verse-end rhyme, deployed elsewhere in traditional verse sporadically, yet always with the same consequences. There is, accordingly, no need to seek the direct influence of foreign models for these features of the poem (although formal similarities with Anglo-Latin verse are indisputable). ${ }^{51}$ The Riming Poem may be 'a lunatic exercise', as has been suggested, ${ }^{52}$ but there is traditional vernacular method in the poet's madness. ${ }^{53}$ Here, as in the passage from The Phoenix, rhyme and reason go hand in hand.

Double alliteration in the a-verse, then, where not triggered by metrical or metricalgrammatical rules, is used by the poets to re-iterate the structure of the line and this was presumably important in an oral form where listeners did not have the luxury of pausing and

${ }^{46}$ In addition to 58a, 77a, 79a, Bliss, Metre, p. 166, counts 80a Ar peet eadig gepenceð and 81a byrgeð him pa bitran synne as hypermetric verses with light first feet and ornamental extra alliteration.

47 Type 2A1 (4a, 11a, 12a, 20a, 28a, 51a, 54a), 2B (43a, 70a), 2C (17a, 39a, 59a, 60a), 3B (15a, 23a, 25a, 71a, 78a), 3B* (1a, 2a, 9a, 10a, 74a, 76a), 3E1 (26a). Prefixes in the dip of 1a, 2a, 9a, 10a, 70a, 74a, 76a, however, furnish a metrical-grammatical explanation for double alliteration in those verses.

${ }^{48}$ The MS has balawun her gehlotene ne bip se hlisa adroren.

49 Amongst the poem's recent editors, Klinck emends; Macrae-Gibson does not. See, respectively, The Old English Elegies: A Critical Edition and Genre Study, ed. A. L. Klinck (Montreal, 1992), p. 87 and Riming Poem, ed. Macrae-Gibson, p. 51.

${ }^{50}$ The first four words are usually given as one verse (either with an as the rhyme word at the end of the line, together with some indication of missing text, e.g. Elegies, ed. Klinck, p. 88, or with editorially added words, e.g. The Exeter Anthology of Old English Poetry: An Edition of Exeter Dean and Chapter MS 3501, ed. B. J. Muir (Exeter, 1994), vol. I, Texts, p. 267). If this is correct, then the a-verse has one stress (and is of a very rare metrical type: e1d), and single alliteration. Perhaps what is left is a complete a-verse with internal rhyme at its end (as in 13a) and the b-verse missing (as at 35b) possibly through eye-skip; if so, then the verse has two stresses, but lacks double alliteration.

${ }^{51}$ See J. W. Earl, 'Hisperic Style in the Old English "Rhyming Poem”, PMLA 102 (1987), 187-96, and also Elegies, ed. Klinck, p. 238: 'The Riming Poem shows the influence of the rhymed verse used in Latin hymns'. She is, however, correct to say that the poem resembles Egill Skallagrímsson's Hofuðlausn in making 'frequent use of two-line units joined by fourfold rhyme linking two pairs of a- and b- verses' (p. 238), but, if there is influence here, its direction is uncertain.

52 See D. Pearsall, Old English and Middle English Poetry (London, 1977), p. 73.

${ }^{53}$ On the development of traditional ways of using verse-internal rhyme in West Germanic poetics, see T. A. Bredehoft, 'Old English and Old Saxon Formulaic Rhyme', Anglia 123 (2005), 204-29. 
re-reading. Even where such alliteration seems to be deployed rhetorically, this essential principle appears also to be in evidence: note, for example, the end of Beowulf (lines 3180-2):

$$
\begin{aligned}
& \text { cwædon pæt he wære wyruldcyninga } \\
& \text { manna mildust ond monðwærust } \\
& \text { leodum liðost ond lofgeornost. }{ }^{54}
\end{aligned}
$$

Orchard remarks that the poet's 'favoured form of artful alliteration appears to lie in the clustering of double alliteration' and that these particular lines bring the poem to a 'fitting close' with 'double alliteration, end rhyme and precisely repeated rhythms in the last two'. ${ }^{5}$ This is an attractive interpretation (given that neither of the a-verses with double alliteration requires it by metre). The alliterative supererogation, however, appears also to be the reaction of a careful (and probably early) poet sensitive to the end-rhyme of suffixes-a fortifying of the line structure at the poem's end that is causally related to the chiming of the superlatives, even though doubtlessly also rhetorical. ${ }^{56}$ Double alliteration that is not required by the metre cannot be divorced from its primary line-structuring function; it operates in a hinterland between the functional and the ornamental.

One further final feature of The Riming Poem is also germane to this discussion of double alliteration. Classen rightly remarks that 'double alliteration is considerably rarer in [vocalic alliteration] than in consonant alliteration'. ${ }^{57}$ Only twenty-five a-verses in Beowulf with vowel alliteration - out of some five hundred such a-verses - show double alliteration in metrical (and metrical-grammatical) types not requiring double alliteration and where the second position is not occupied by a poetic word. ${ }^{58}$ The list given above of the twenty-three

54 'They said that, among the kings of the world, he was the most benevolent of men and the most courteous, most gracious to his people and most eager for glory.'

${ }^{5}$ A. Orchard, A Critical Companion to 'Beowulf' (Cambridge, 2003), pp. 61 and 66-7. Perhaps contributing to the increased rhetoricity of the conclusion of the poem is the extensive passage of interlaced alliteration at lines 3153-8.

${ }^{56}$ With these lines from Beowulf may be compared the third section of the genealogy of Æpelwulf running from Cerdic to Woden:

Cynric Cerdicing, Cerdic Elesing,
Elesa Esling, Esla Giwising,
Giwis Wiging, Wig Freawining,
Freawine Friðogaring, Friðogar Bronding,
Brond Bældæging, Bældæg Wodening.

As R. W. Chambers observes 'the alliteration is perfect' in which 'every line attains double alliteration in the first half'; he does not note, however, that all ten verses close with the repeated suffix -ing. According to Chambers, these poetic lines are 'pre-literary' (some evidence for which is possibly suggested by the fact that this section of annal 855 in The AngloSaxon Chronicle repeats that found in annal 597 in the genealogy of Ceolwulf and in the preface to the Parker MS). See R. W. Chambers, Beowulf: An Introduction to the Study of the Poem with a Discussion of the Stories of Offa and Finn with a Supplement by C. L. Wrenn (Cambridge, 1963), pp. 316-17, and H. B. Woolf, The Old Germanic Principles of NameGiving (Baltimore, MD, 1939), pp. 247-8.

${ }^{57}$ Classen, Vowel Alliteration, p. 25; his figures, however, are not correct. There seems no reason for this disparity if vowel alliteration is merely consonant alliteration which is orthographically disguised.

${ }^{58}$ In the a-verses of lines 251, 287, 444, 637, 784, 960, 998, 1000, 1044, 1129, 1187, 1225 , 1300, 1500, 1621, 1766, 2214, 2248, 2564, 2624, 2772, 2834, 2951, 3075, 3135. The prefix 
lines in the traditional corpus with true verse-end rhyme and extra a-verse alliteration shows not a single example of vowel alliteration, although three or four lines of it should certainly have been expected given that, on average, about one in six lines in the corpus show it. The Riming Poem has less vowel alliteration than any poem in the corpus-merely five lines of it, or slightly less than six per cent ${ }^{59}$ _but the most double alliteration. Of the poems over fifty lines in length in the corpus, eight of the thirteen with the least vowel alliteration are also amongst the thirteen with the most double alliteration. ${ }^{60}$ Conversely, eight of the thirteen poems with the most vowel alliteration are also amongst the thirteen with the lowest proportion of double alliteration. ${ }^{61}$ Broadly speaking, therefore, in Old English poems, double alliteration and vocalic alliteration occur in inverse proportion and so the phonetics of supererogatory alliteration within the line differs in some material ways from that of functional alliteration, with consonant alliteration — phonetically more prominent-being favoured. Further evidence of this phonetic contrast can readily be outlined. The two poems making the most use of consonant cluster alliteration are also amongst those with the highest proportion of double alliteration: The Riming Poem and Riddle 3, and, at the other end of the scale, a number of the poems with the least use of double alliteration show no evidence at all of consonant cluster alliteration-An Exhortation to Christian Living, Lord's Prayer II, A Prayer-even though more than two-thirds of their lines still alliterate on consonants. Or, again, vowel alliteration in self-alliterating compounds is hardly to be found in Beowulf: although some $18 \%$ of light verses (in which compounds congregate) display vowel alliteration in the poem, only one of the thirty self-alliterating compounds in light verses in the poem shows it. ${ }^{62}$ Indeed, only one selfalliterating compound in the whole corpus begins with a noun opening with a vowel, ${ }^{63}$ although the corpus provides twenty-five examples of such compounds opening with nouns alliterating on $w$-, the next commonest word-initial sound in the system. ${ }^{64}$

\section{a. ii Triple alliteration}

The opportunity for functional triple alliteration to occur is limited to a-verses with three stresses, that is, to hypermetric a-verses, heavy a-verses, and normal a-verses containing a compound. It is not known whether the rules countenanced its use; as a third alliteration in a

un- carries the second stress in a number of these (287, 444, 960, 1129, 2214, 2564, 2624, 3135 ) and an alternative scansion with single alliteration and stress on the stem following the prefix is not impossible. Poetic words beginning with stressed vowels occupy the second position in lines $6,573,592,732,816,1185,1228,1238,1254,1281,1547,2133,2140,2188$, 2535, 2557, 2622, 2695, 3007.

${ }^{59}$ Lines 23, 31, 69, 74, 80.

${ }^{60}$ With the percentage of vowel alliteration given first: Rim 5.7, 96.6; Max II 7.6, 66.7; Max I 9.8, 69.1; Res 11.0, 60.2; Fort 11.2, 57.1; Wan 12.2, 58.3; MSol 13.0, 55.1; Rid 3 13.5, 60.8.

${ }^{61}$ With the percentage of vowel alliteration given first: Met 28.6, 25.6; Exhort 28.0, 12.2; $\mathrm{Pr}$ 27.8, 22.8; LPr II 26.8, 26.8; Instr 25.0, 14.8; Creed 24.1, 24.1; JDay II 23.2, 21.9 ; PPs 22.3, 17.0. For discussion of the metre and style of this group of poems, see M. Griffith, The Method of Composition of Old English Verse Translation with Particular Reference to 'The Metres of Boethius', 'The Paris Psalter' and 'Judgment Day II' (unpublished dissertation, Oxford, 1984). ${ }^{62}$ Beo 2338a eallirenne, and this may, instead, be construed as two words: see Klaeber's Beowulf and The Fight at Finnsburg, ed. R. D. Fulk, et al. (Toronto, 2008), p. 242.

${ }^{63}$ And 532a ar-yða.

${ }^{64}$ wclwang, wcelwulf, wœepenwiga, wcepengewrixl, waruðgewinn, weallwala, wederwolcen, weohweorðing, wiggeweorpad, Wistlawudu, wintergewcede, wintergeworp, gewinworuld, womwyrcende, woruldwela, woruldwidl, woruldwite, woruldwunigende, wuldorwerod, wuldorword, wundorworc, wundorworuld, wundorwyrd, wynwyrt, wyrtwela. 
line would normally signal to the audience the head stave of the b-verse, its use should, perhaps, be regarded as licentious, rather than supererogatory. It is certainly very scarce. Four of the thirteen instances in the corpus of 'double' hypermetric a-verses display it:

$\begin{aligned} \text { Dan 237a } & \text { Engel in pone ofn innan becwom } \\ \text { Max I 46a } & \text { trymman ond tyhtan pæt he teala cunne } \\ \text { 64a } & \text { widgongel wif word gespringed } \\ \text { 100a } & \text { Wif sceal wip wer wære gehealdan }\end{aligned}$

Such a-verses are metrically analogous to whole lines, ${ }^{65}$ so that alliteration in the first three positions coupled with the absence of it from the last stress is mimetic of normal line structure. Some editors have edited some of these a-verses as whole lines. ${ }^{66}$ Why it occurs in these four but not in the other nine is unknown. ${ }^{67}$ Nine examples occur in the considerably larger corpus of 'single' hypermetric verses, without any obvious cause. ${ }^{68}$ Hieatt views these as part of a larger structural contrast between normal and hypermetric verse, noting that 'single alliteration in the on-verse is common in normal lines, [but] it is so rare as to be suspect in hypermetric lines, while, on the other hand, significant triple alliteration occurs only in hypermetric lines' ${ }^{69}$

Despite Hieatt's remark, triple alliteration is found in a few verses that are not hypermetric. They are numerically insignificant, but aesthetically interesting, for the proximity of the third alliteration (on a syllable bearing some degree of stress) to the other two is so very close that a claim that poets and audiences were not aware of it is simply not credible. Eight heavy verses display it: functionally so in GenB 584a, Sat 644-5, ChristC 1630a, Phoen 394a, Durham 15a, ${ }^{70}$ and Seasons $229 a ;{ }^{71}$ possibly functionally in MCharm 4.16a; ${ }^{72}$ and, apparently ornamentally, in PPs 67.12.1a. The context in Christ $C$ is suggestive (lines 1629b-31):

Hy bræcon cyninges word,

beorht boca bibod; forpon hy abidan sceolon

\footnotetext{
65 See Bliss, Metre, pp. 95-6 and 134.

${ }^{66}$ Farrell edits Dan 237a as a whole line (Daniel and Azarias, ed. R. T. Farrell (London, 1974), p. 61); Williams treats Max I 46a in the same way (Gnomic Poetry in Anglo-Saxon, ed. B. C. Williams (New York, NY, 1966), pp. 120 and 133). If so, then the following lines are short of a b-verse and show continued alliteration.

${ }^{67}$ Nine of the thirteen a-verses are in Maxims I (ll. 4, 36, 46, 58, 64, 66, 100, 164, 185), one is in Maxims II (l. 42), Wan 65a is in a sententious context, so that this kind of expanded verse is closely associated with gnomic poetry.

${ }^{68}$ Eight times with the third alliteration on the final stress: Dan 204a, 266a, 270a, ChristC 1162a, Sea 106a, Jud 2a (with verse-end rhyme), MRune 28a, Max II 3a. These verses do not share any metrical feature that distinguishes them from other hypermetric a-verses. MCharm 1.51 Erce, Erce, Erce is either hypermetric or anomalous. On GenB 444a, see below.

${ }^{69}$ C. B. Hieatt, 'Alliterative Patterns in the Hypermetric Lines of Old English Verse', MP 71 (1974), 237-42, at 241. Hieatt's focus here is rhythmical, see also her 'A New Theory of Triple Rhythm in the Hypermetric Lines of Old English Verse', MP 66 (1969), 1-8.

${ }^{70}$ And breoma bocera Beda: the verse is unmetrical; given the subject, honorific use is quite possible.

${ }^{71}$ Etan ostran eac, 'to eat oysters too'. The context concerns the immoderate consumption of exotic foods and drinks and this, perhaps, lies behind the alliterative hyperbole.

${ }^{72}$ Syx smiðas scetan: but the b-verse has double alliteration on a different sound! The alliterations of the Metrical Charms differ from those of the rest of Old English poetry.
} 
in sinnehte, sar endeleas. ${ }^{73}$

The final fate of the damned is revealed. The cyninges word which they have broken is varied by the triple alliterating phrase beorht boca bibod, the 'clear' or 'radiant' command of books; these books are clearly the books of the Bible, the word of God. ${ }^{74}$ The high register of the subject appears to have stimulated extra, honorific, alliteration, albeit at the expense of metrical clarity (the verse is ambiguously Type D or E) ${ }^{75}$ This is not this poet's only use of special effects for this purpose: ornament dominates the awesome judgement of God on the damned in lines 1379-1514 with this single speech showing almost all of the hypermetric verses of this poem together with frequent continued alliteration. ${ }^{76}$ After another scene of pitiable damnation, the poet of Christ and Satan enjoins us to remember how the blessed are saved (lines 644-5):

Georne purh godes gife gemunan gastes bled, hu eadige pær uppe sittað. $^{77}$

The affirmation of the importance of divine grace in this process stimulates triple alliteration: the verse would be alliteratively normal and the sense of the clause intact without the opening adverb, so that the effect appears mannered. ${ }^{78}$ In the occurrence in The Phoenix, a displaced verse-initial finite provides the extra alliteration (lines 393-4):

$$
\begin{aligned}
& \text { Habbap we geascad } \\
& \text { worhte wer ond wif }
\end{aligned}
$$

If this extra alliteration on the verb arose by chance then it was serendipitous, for the subject again is divine in nature: God's creation of Adam and Eve. In Genesis B 583-4a, the snake affirms to Eve that he knows heaven:

Ac ic cann ealle swa geare engla gebyrdo heah heofona gehlidu. ${ }^{80}$

\footnotetext{
73 'They broke the word of the king, the clear command of books; therefore they... will have to dwell in eternal night'. The translation is from Old English Poems of Christ and His Saints, ed. and trans. M. Clayton, DOML 27 (Cambridge, MA, 2013), p. 85.

${ }^{74}$ Compare, perhaps, Sat 236b byrhtword.

${ }^{75}$ As is Seasons 229a.

${ }^{76}$ Hypermetric clusters are found at ll. 1380-5, 1422-7, 1487-8, 1495-6, 1513-14; continued alliteration is evidenced at ll. 1387-8, 1396-7, 1403-4, 1412-14, 1431-3, 1439-40, 1443-4, 1454-5, 1469-70, 1479-80, 1487-8, 1490-1, 1496-7, 1501-2.

77 'Let us eagerly be mindful, through the grace of God, of the soul's glory, how...the blessed...sit there on high'; the translation is from Christ and his Saints, ed. and trans. Clayton, p. 345.

${ }^{78}$ Although there would, then, be a breach of Kuhn's Second Law, which is strongly observed in this poem: see H. Momma, The Composition of Old English Poetry, CSASE 20 (Cambridge, 1997), p. 73.

79 'We have learned that the Almighty wrought man and woman through his faculty for wondrous things'; the translation is from Bradley, Anglo-Saxon Poetry, p. 294.

80 'But I know entirely well the orders of angels, the high roofs of the heavens'; the translation is from Old Testament Narratives, ed. and trans. D. Anlezark, DOML 7 (Cambridge, MA, 2011), p. 45.
} 
Once again it seems that celestial subject has prompted unusual extra alliteration, even though the speaker is not angelic. ${ }^{81}$

PPs 67.12.1a displays triple alliteration with the extra alliteration falling on a finite verb in the first dip:
God gifeð gleaw word godspellendum, syleð him modes mægen, se pe is mihtig kynincg and wlites wealdend. ${ }^{82}$

Only this a-verse in The Metrical Psalms contains alliteration on three separate words. ${ }^{83}$ Two lines follow in which there is double alliteration in the a-verse. The Metrical Psalms depart from metrical and alliterative norms in a variety of ways, but the general tenor of the changes is towards a dilution of the alliterative form, with diminished double alliteration and fewer examples of metrical types requiring it. This psalm verse, however, moves in the opposite stylistic direction, with functional double alliteration and ornamental triple alliteration, and so appears, by contrast, to be all the more prominent in its context than it would had it occurred in another poem. The divine word is once again the subject and appears to have prompted the unusual supplementary alliteration. Two normal verses and one hypermetric verse elsewhere in the corpus may be similarly motivated. Two of God's speeches in Andreas contain a-verses opening with clause-initial alliterating imperatives unstressed in the initial dip and which precede alliterating stressed elements:
And 107
Gepola peoda brea!
1441
Geseoh nu seolfes swæðe

Both speeches are responses to requests for help from apostles in dire need. In the first (And ll. 97-117), God replies to Matthew affirming his commitment to him, his voice emanating from heaven in marvellous fashion (93a wrætlic); in the second (ll. 1431-45), God re-iterates to Andrew his promise to protect and strengthen his twelve chosen followers. The speeches are generically identical and contain divine commands which share the ornamental use of triple alliteration. ${ }^{84}$ And the subject of the hypermetric verse in MSol II.338a is also, as in ChristC 1630a, God's sentence at the Day of Judgement:

MSol II.338a Hwa dear ðonne dryhtne deman, ðe us of duste geworhte

Saturn asks Solomon a Christianised, but blasphemous, version of Juvenal's quis custodiet ipsos custodes: ${ }^{85}$ 'who will judge Christ on Judgement Day when he judges all?' Solomon

${ }^{81}$ A contrast may be intended with 1. 764a secan helle gehliðo. See The Saxon Genesis, An Edition of the West Saxon 'Genesis B' and the Old Saxon Vatican 'Genesis', ed, A. N. Doane (Madison, WI, 1991), p. 297: 'after his boast about heavenly experiences at 584...the devil is reduced to scuttling into an obscure covered place'.

82 'To those who proclaim good news, God will impart wise words, will bestow strength of purpose on them, he who is mighty king and ruler in splendour.' The translation is from Old English Psalms, ed. and trans. P. P. O’Neill, DOML 42 (Cambridge, MA, 2016), p. 245.

${ }^{83}$ Palatal and velar $g$ - alliterate together normally in $P P s$, see, for example, the common alliteration there of god and georne (52.3.4, 4.3, 5.4, etc.).

${ }^{84}$ Note the view of the poem's most recent editors: 'it seems likely that the extra alliteration is not accidental, and that the poet has reinforced the line without regard for traditional prosody'; see Andreas: An Edition, ed. R. North and M. D. J. Bintley (Liverpool, 2016), p. 290.

85 'Who will guard the guards themselves?'; see Juvenal, Satire VI, lines 347-8, Juvenal and Persius, ed. G. G. Ramsay (Cambridge, MA, 1979), p. 110. 
answers the question with a question that implies its own answer: 'Who dare then judge the Lord who wrought us from dust?' The alliterative supererogation indicates rhetorical stress on the undisplaced verb of the rhetorical question. ${ }^{86}$ These various verses, taken together with the widespread use of extra alliteration in divine speeches in Genesis $A^{87}$ and in the divine judgement at the end of Christ $C$, suggest a tradition of Christian poets who thought it fitting to give special treatment to divine subject and especially to the divine word. ${ }^{88}$

Nine normal verses and one hypermetric verse with self-alliterating Class One compounds ${ }^{89}$ either preceding, or following, another stressed element, also display triple alliteration:

compound first; normal

\begin{tabular}{|c|c|}
\hline \\
\hline \multicolumn{2}{|c|}{$\begin{array}{l}\text { Dan 539a heahheort and hæðen } \\
\text { ChristC 1006a woruldwidles wom }\end{array}$} \\
\hline Fort 71a & \\
\hline Ruin 20a & dilWdidt \\
\hline Вео 743а & synsnædum swealh \\
\hline
\end{tabular}

${ }^{86}$ Anlezark, however, regards the passage as corrupt: see The Old English Dialogues of Solomon and Saturn, ed. D. Anlezark, Anglo-Saxon Texts 7 (Cambridge, 2009), p. 127. An undisplaced alliterating finite also precedes two alliterating stressed elements at Dan 245a (immediately following a cluster of hypermetric verse), El 464a (an imperative opening a speech), Ruin 35a; one is placed in the dip between two alliterating stressed elements at Max I 132a. With verbs of low stress, incidental triple alliteration is also rare (e.g. Rim 15a, Hell 4a, Mald 113a, MCharm 3.10a), even though many open with sounds that alliterate frequently. In Mald 96a wodon pa wcelwulfas, the verb alliterates because it is poetic in register (see M. Griffith, 'Alliterating Finite Verbs and the Origin of Rank in Old English Poetry', Old English Philology: Studies in Honour of R. D. Fulk, ed. L. Neidorf, et al., Anglo-Saxon Studies 31 (Cambridge, 2016), pp. 103-21). In PPs (and PsFr) 89.15.1a Gehweorf us hwcethwiga, an alliterating finite precedes a self-alliterating adverb, perhaps ornamentally. See below on Mald 2a, 74a. Triple alliteration involving other undisplaced sentence particles is rare; a possible ornamental example may be Wan 72: hwider hrebra gehygd hweorfan wille with cluster alliteration in a collocation (cf And 405a hwider hweorfað we, Max II 58 hwyder...hweorfan, Beo 163 hwyder...hwyrftum).

${ }^{87}$ See M. Griffith, 'The Register of Divine Speech in Genesis A', ASE 41 (2013), 63-78, at 78, and n. 46.

${ }^{88}$ See the above article for details and discussion.

${ }^{89}$ In a Class One compound, both elements 'retain their full semantic value' and so show metrical stress on both elements: see Kendall, Metrical Grammar, p. 160. Very rarely, a selfalliterating compound of Class Two or Three occurs after an undisplaced and alliterating finite verb ( $P P s$ 89.15.1a, 140.12.1); the suffix presumably shows alliteration by chance, as too in verses such as Beo 1584a laðlicu lac.

90 The compound is, however, contested: see A. L. Klinck, 'A Damaged Passage in the Old English Ruin' SN 58 (1986), 165-8 who reads instead weall walanwirum, with *walanwir meaning 'strip of metal'.

${ }^{91}$ For interpretation of synsnced as a Class One compound meaning 'sinful morsel', see F. C. Robinson, 'Lexicography and Literary Criticism: A Caveat', Philological Essays: Studies in Old and Middle English Language and Literature in Honour of Herbert Dean Meritt, ed. J. L. Rosier (The Hague, 1970), pp. 99-110, at 102-3. Beowulf, ed. Fulk, p. 441, however, takes it to mean 'huge morsel', with syn- a stressed prefix (with nonce sense 'immense', rather than the usual meaning 'perpetual, permanent') and the whole a Class Two compound, presumably with 


$\begin{array}{rll}\text { hypermetric } & \text { GenB 444a } & \text { hæleðhelm on heafod asette } \\ \text { compound second; normal } & \begin{array}{l}\text { And 1275a } \\ \text { Hell 12a }\end{array} & \text { swungen sarslegum } \\ & \text { Hell 19a } & \text { Opne in pæt eorðærn wæs pæt eorðærn } \\ & \text { MSol II.446a } & \text { weana wyrtwela. }\end{array}$

A variety of arguments - empirical, psychological, phonetic, lexical-all point to the metrical and/or rhetorical significance of self-alliterating compounds. The poets strictly control their placement: they occur only in the a-verse (where use in the b-verse would result in prohibited double alliteration). ${ }^{92}$ They also occur mainly in light verses, indicating a metrically relevant half-stress; where, as here, another stressed element appears, scansion becomes potentially difficult. Brooks dismisses the problem, stating, somewhat paradoxically, that in a verse such as And 532a ar-yða geblond, 'the tumult of water-waves', 'the second element in the compound, having half-stress, does not alliterate'. ${ }^{93}$ That an audience, having recognised the first stress and the functional alliteration of the vowel of ar-, did not then-upon hearing the second element of the compound in the very next syllable-entertain the possibility of double alliteration on vowels in the compound seems most implausible. ${ }^{94}$ In cases, furthermore, where the second alliteration repeats a consonant cluster (as in And 1021a clustorcleofa), ${ }^{95}$ or anticipates the same cluster heading the b-verse (e.g. Ex 496 deaðdrepe: drihte), ${ }^{96}$ or where the repeated sound is a rarely alliterating one (e.g. And 102a on nearonedum), ${ }^{97}$ or where the second element is a poetic word (as in Ex 238a bealubenn), ${ }^{98}$ which as a simplex always, or

incidental extra alliteration. See, also, D. L. Hoover, 'Evidence for primacy of alliteration in Old English metre', ASE 14 (1985), 75-96, at 81, n. 16.

92 In Beo 395b guðgeatawum is doubtful and probably stands for guðgetawum. GenA 1945b, Max I 31b, Hell 3b, Instr 137b are the only apparent exceptions. Max I 31b is better construed as two separate words, as in the manuscript (see DOE er-adl). Instr 137b is alliteratively and metrically anomalous in a non-standard poem. See below on GenA 1945b. Wife 15b $<$ herheard $>$ (with a line break after <her $>$ ) has been interpreted variously, but probably represents hearg-eard, 'an abode in a grove' (so DOE). Further on such compounds, see D. L. Hoover, A New Theory of Old English Metre, American University Studies IV 14 (New York, NY, 1985), pp. 69-73.

${ }^{93}$ Andreas and The Fates of the Apostles, ed. K. R. Brooks (Oxford, 1961), p. 80.

94 Especially so as And 532a appears to be a nonce, playful expansion of the traditional compound eargebland, 'tumult of waters' (attested at And 383a, El 239a, Met 8.30a, Brun 26b), in which the second element has been postponed and an alliterating noun interposed. Where self-alliterating compounds appear in normal verses, they usually appear in first position in types 2A3b (Ex 149, And 1548, 1549, 1596, GuthB 1078), 3E2 (Dan 553, And 226, 728, Phoen 292, Prec 57, Max I 147, 196, Met 24.23, MRune 5, Men 210), and 3E*2 (Whale 45a, Wife 45a, Winfrid 2a), in which double alliteration predominates; perhaps, in such verses, the second alliteration of the compound was felt to substitute for the alliteration of the second full stress.

${ }^{95}$ Compare Az 161a brynebroga, Beo 2946a swatswaðu, Jud 240a swyrdgeswing, all of which, like clustercleofa, are hapax legomena.

96 ChristB 745 heahhleopu: hlypum, Phoen 292 bleobrygdum: breost, MCh 1.76 beorhtblowende: gebletsod.

${ }^{97}$ Compare ChristA 196a, 247a, Met 5.20a, 10.41a riht(ge)ryne, GenA 1434a streamstcð, GenA 959a, Ex 372a tuddorteonde, Beo 178a peodprea.

${ }^{98}$ Compare Max I 196a bealublonden, Beo 851a fenfreoðo, GenA 1852a folcfrea, And 1549a, 1596a forhtferhð, GuthB 1344a freorigferð, PPs 89.7.2a hathyge, Rid 3.27a hopgehnæest, FAp 
nearly always, alliterates functionally, the view that the extra alliteration in these compounds is insignificant is also unconvincing. Triple alliteration in the above listed verses cannot, accordingly, just be ignored. Hell 12a and 19a, however, may be discounted. ${ }^{99}$ Of the remaining seven normal verses, six contain compounds whose occurrence in the poetry is unique. ${ }^{100}$ All five of the compounds in first position are hapax legomena. GenB 444a hæeleðhelm may also be hapax. ${ }^{101}$ Wyrtwela is a prose word appearing in poetry only at MSol II.446a, ${ }^{102}$ and in a passage of interlaced alliteration. ${ }^{103}$ The context of Beo 743a, the eating of Hondscioh, displays numerous sound effects. And 1275 shows, also, cluster alliteration; GenB 444a participates in enjambed alliteration. This correlation of unique lexis, rarely attested triple alliteration, and other types of extra alliteration is very striking and seems most unlikely to be the product of chance. If these compounds are the inventions of these poets-and hapax legomena are very disproportionately attested in this type of word-then self-conscious artistry, perhaps of an exhibitionist sort, would appear to be the only explanation for the alliterative abundance. ${ }^{104}$

\section{b. i Cluster alliteration}

Almost all the poets knew that three consonant clusters ( $s c-$-, sp-, st-) functioned as unitary alliterative constituents, alliterating in the system only with themselves. ${ }^{105}$ Some late poets show some interest in separating other s- clusters. ${ }^{106}$ Poets, therefore, may have been sensitive to the broader artistic possibilities of cluster alliteration; the versifier of The Metres of Boethius, for example, uses cluster alliteration across a-verses which have multiple requirements for

76a lindgelac, And 827a, 1552a lyftgelac, Dan 387a, El 796a, GuthA 146a, Jul 281a lyftlacende, Wan 34a selesecg, Rid 14.1a wæepenwiga. All, apart from lyftlacende, are either hapax or occur only in a single poem.

${ }^{99}$ Hell 3b eorðcerne bipeaht exceptionally shows this self-alliterating compound heading a bverse; accordingly, an un-metathesised form of the second element is to be understood in all three instances (see Campbell, Grammar, §193(d), n. 4, and compare ClGl 1388 hypogium: eorpren).

100 Sarslege occurs also at GuthA 227a, Jul 341a, 547a.

${ }^{101}$ Its form is unique (but compare Whale 45 heolophelm); for discussion of whether the word too is unique see Saxon Genesis, ed. Doane, pp. 277-8, and The Old English Physiologus, ed. A. Squires (Durham, 1988), pp. 85-6. If the second element of the compound was vulnerable to loss of $h$ - (see Campbell, Grammar, §468, and compare proper names with -(h)elm such as AElfelm, Byrhtelm), then this compound, too, falls out of the list above.

${ }^{102}$ See Stanley, 'Prosaic Vocabulary', p. 40, and cf. Met 12.46.1.

103 See below on this.

${ }^{104}$ I count 150 different self-alliterating compounds attested 213 times in the surviving corpus; of these one hundred are hapax legomena; five occur more than once in the same poem only; and twelve occur once in verse, but also in prose or glosses.

105 Alliteration of sc- with s- occurs in The Metrical Psalms (e.g. 68.7.2). The general alliterative rule, however, follows from a rule of Germanic grammar. In reduplication in Gothic these word-initial consonant clusters (unlike others) are treated as indivisible: see J. Kurylowicz, Die sprachlichen Grundlagen der altgermanischen Metrik (Innsbruck, 1970), pp. 13-16. Their second elements (voiceless stops) differ from, and must have been felt to be more prominent than, those of other clusters (liquids, nasals, and spirants).

${ }^{106}$ See Judith, rev. ed. M. Griffith (Exeter, 2001), p. 28. 
double alliteration, presumably as a kind of rhetorical superogation. ${ }^{107}$ But little critical attention has been devoted to this type of alliteration. ${ }^{108}$ Verses quoted above such as ChristB 593a swa prymmes præece, ChristB 594a swa mid dryhten dream and MSol II.267a swiðe swingeð and lines such as Phoen 16 ne hregles hryre, ne hrimes dryre show that some poets sometimes felt that rhyme encouraged the use of repeated clusters as even further fortification of the alliterative structure. ${ }^{109}$ Certainly, the alliteration of consonant clusters is much commoner in The Riming Poem than in any other Old English poem, ${ }^{110}$ with a quite dazzling variety of clusters exemplified in a poem of very modest length - a wider range, indeed, than in the entirety of Genesis A. ${ }^{111}$ Most of these lines also show the cluster alliterating across all three alliterating positions; ${ }^{112}$ by way of contrast, The Metrical Psalms, a text with more than five thousand lines of verse, shows not a single example of this. A number of the words alliterating on clusters in the poem, however, alliterate together elsewhere in the corpus, as if the poet were collecting together established collocations from his poetic heritage. Blced 'prosperity', bliss 'happiness' and blissian 'to delight' alliterate together in lines 35a and 54 and do so commonly elsewhere (along with bletsian 'to wish happiness', bletsung 'blessing', blipe, 'joyful'). ${ }^{113}$ Dream 'joy' and dryht(-) 'nobility', 'lord' are linked at line 39a dream dryhtlic and line 55 dreamas: dryhtscype. They alliterate together elsewhere on more than thirty occasions (this being half of the instances in which dream alliterates in the corpus). ${ }^{114}$ The notion of happiness is, however, quite lacking from the actual context in the poem: past joys and past lordship are contrasted in The Riming Poem with present misery; theme and collocation are in tension. A similar tension marks the use of the collocation elsewhere: noble men in Heorot live happily (Beo 99 drihtguman: dreamum), but we know that Grendel is coming; the joys of the Lord (Sea 65a dryhtnes dreamas) contrast for the Seafarer with his current situation in 'this dead transitory life'; the Lord shapes a house devoid of joys for the fallen angels (GenA 40 dreama leas: drihten), and so forth. The poetic interest seems generally to lie in the play of the sense of the collocation against that of the broader context. ${ }^{115}$ The

107 The Old English Boethius: An Edition of the Old English Versions of Boethius's 'De Consolatione Philosophiae’, ed. M. Godden and S. Irvine (Oxford, 2009), vol. I, pp. 126-7.

${ }^{108}$ For a brief overview, see D. Minkova, Alliteration and Sound Change in Early English (Cambridge, 2003), pp. 241-3.

${ }^{109}$ See also El 1238a, Rid 2.5, Jud 23, 29.

${ }^{110}$ See Appendix One and Six. Gifts, Deor, Exhort, Pr, LPr II are devoid of cluster alliteration; it is also infrequent in PPs. Rim, Rid 3, 46, Ruin, Metre 3 are rich in it, and MRune comparatively rich in it. Rim shows more than twice as much as the poem with the next highest frequency, Rid 3.

111 Thirteen different clusters are instanced twenty-two times in its eighty-seven lines: $b l$ - at lines 4, 35a, 53, br- 46, dr- 39, 55, fl- 47, 62, 72, fr- 32, 38, gl- 3, gr- 49, 66, 71, hl- 28, 79, hr43a, scr-13a, sw- 29, tr- 57, wr- 64. Sc- alliteration occurs also at 27, with st- at 22 and 58. Obviously, cluster alliteration cannot occur in lines of vocalic alliteration (5 times in Rim) or in lines alliterating on $l-, r-, m-, n-(17$ times in Rim).

112 Seventeen of its twenty-two lines with cluster alliteration: see Appendix One.

113 GenA 14, 192, 1761, 2333, And 1719, Dream 149a, ChristC 877, 1256a, 1346a, GuthA 497, 608, etc. See Appendix One.

${ }^{114}$ At GenA 40, 81, GenB 257, 485a, Ex 547, Dan 257a, Sat 44, 68, 82, 173, 313, And 874, Dream 140, 144, ChristB 594a (also with rhyme), ChristC 1641, 1644, GuthA 123, 464, 740, GuthB 901, 1083, 1101a, Phoen 138, 560, 658, Sea 85-6, Fort 55, Pan 55, Rid 28.7, Beo 99, Men 58, KtHy 18.

115 On contrast as a principle of Old English poetic composition (including contrasting collocations), see J. Mandel, ‘Contrast in Old English Poetry’, Chaucer Review 6 (1971), 1-13. 
occasional agreement of collocation and context, on the other hand, stimulates repetition of the collocation, apparently for reasons of emphasis, in Christ $C$ lines 1641-4, and The Dream of the Rood lines 139-44 where the heavenly Lord and heavenly joy are contemplated:

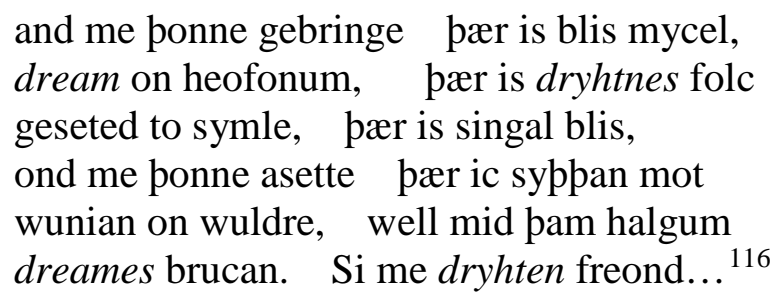

The dreamer turns, after his vision, to his hope for heavenly reward through the intercession of the cross. The repeated collocation (along with the tautology of 139b and 141b) conveys the strength of the dreamer's desire, but, perhaps also-given the general association of the collocation in the corpus with the possibility of its opposite, and the dreamer's consciousness of his own sinfulness - a sense of anxiety. ${ }^{117}$

Another line of The Riming Poem with cluster alliteration proves to be part of a network of words with assonantal and rhyming connections that goes beyond simple collocation or the strengthening of the alliterative structure in the face of rhyme:

$\begin{array}{ll}\text { hlude hlynede, hleopor dynede } & \text { Rim } 28 \\ \text { hloh ond hlydde, hlynede ond dynede } & \text { Jud } 23 \\ \text { hwælmere hlimmeð, hlude grimmeð } & \text { Rid } 2.5 \\ \text { hlud purh heardne, hleoðor dynede } & \text { And } 739 \\ \text { hlude bi hearpan hleopor swinsade } & \text { Wid } 105 \\ \text { Đær wæs hælepa hleahtor, hlyn swynsode } & \text { Beo } 611 \\ \text { hlinsade hlude hleahtor wæs gryrelic } & \text { Rid } 33.3 \\ \text { and hlynnende hlude streamas } & \text { PPs } 73.14 .2 \\ \text { hofan and hlynsedan hludan reorde } & \text { PPs } 92.5 .2 \\ \text { pa hleoðrade hludan stefne } & \text { And } 1360 \\ \text { hlude hlihhan, ac heo helltregum } & \text { GenA } 73 \\ \text { hlude hlummon. Dæs se hlanca gefeah } & \text { Jud } 205\end{array}$

That this is indeed cluster alliteration (rather than reduced alliteration on $l$-) is shown in a number of these cases by $h l$ - alliterating with $h$ before a vowel or before another consonant (Rid 2.5, And 739, Wid 105, Beo 611, GenA 73). ${ }^{118}$ Threading through these lines is a set of nouns, adjectives and related verbs all of which lie within the single semantic field of words

116 ، ... and bring me to where there is great bliss, joy in heaven, where the Lord's people are seated at the feast, where there is everlasting bliss, and will set me down where I may then dwell in glory, participate fully in joy with the saints. May the Lord be a friend to me...'. The translation is from Christ and his Saints, ed. and trans. Clayton, p. 171.

117 See, for example, ll. 13b-14a: synnum fah, forwunded mid wommum.

${ }^{118}$ For $h l-/ h$ - alliteration in Judith, note 1.251 hlaforde: hilde. On the disappearance of $h$ before a consonant in some late texts, see E. Sievers, An Old English Grammar (Boston, 1903), §217, n. 2. 
denoting noise and the making of noise, ${ }^{119}$ particularly the sound of voices, ${ }^{120}$ and of music or poetry. ${ }^{121}$ These words, and semantically related words in the poetry beginning with $h l-$, also alliterate elsewhere with $h l$ - (rather than $h$-, or other $h$ - clusters) with frequency. ${ }^{122}$ They form only a modest proportion of the body of words in the poetry opening with $h l-$, and words opening with $h l$ - form only a very small sub-set of words opening with $h$ - (and other $h$ - clusters) so that the correlation across these lines of sound and sense is remarkable. Indeed, of the thirtyone lines in the poetic corpus displaying cluster alliteration on $h l-$, twenty-five involve alliteration on words from this semantic field. ${ }^{123}$ Even where they do not cluster together in alliteration, such words tend to congregate together: when, for example, the poet of The Seafarer speaks of the noise of the sea, of birds, and of men, he makes liberal use of them, along with other alliterative effects (lines 17-21, lines 17-18 with continued alliteration, line 20 with enjambed alliteration):
bihongen hrimgicelum; hægl scurum fleag;
pær ic ne gehyrde butan hlimman sæ
iscaldne wæg, hwilum ylfete song;
dyde ic me to gomene, ganetes hleopor
ond huilpan sweg fore hleahtor wera. ${ }^{124}$

What we are seeing here is the shared poetic use of an Old English phonaestheme: because so many of the words in this semantic field begin with this sound, word-initial hl- came to be associated with the idea of sound, especially vocal sound. ${ }^{125}$ There are no studies of Old English phonaesthemes, or of the poets' uses of them. Quirk's well-known article on collocation barely touches upon the issue. ${ }^{126}$ Yet, in many languages, words that sound alike

${ }^{119}$ Hleopor 'song', 'voice' and hleoprian 'to sing', 'to speak'; hlyn 'clamour' and hlynnan 'to clamour', hlynsian 'to resound', hlimman 'to roar'; hleahtor 'laughter' and hlihhan 'to laugh'; hlud/e, 'loud/ly' and hlydan 'to make a loud noise'.

${ }^{120}$ The merrymaking of Holofernes in his hall in Jud 23, the jubilation of the Danes in Heorot in Beo 611, the inhuman voice of the stone angel in And 739, and of the devil in And 1360.

${ }^{121}$ The sound of the harp in Rim 28, and of the poet singing to the harp in Wid 105.

${ }^{122}$ At the following points: behlehhan GuthB 1357, gehlceg JDay I 15, hleahtor JDay II 235, hleopor GenA 1693, Dan 178, Phoen 12, hlihhan GenA 1582, hlimme ('torrent') PPs 123.4.2, hlisa Az 85, Rim 79, hlud Rid 3.24, PPs 123.4.2, CPEp 20, MCharm 4.3, hlynnan Beo 1120, hlyst Dan 178. Compare also Rid 8, 'Song-bird' in continued alliteration: hlude...hleopre (ll. 3-4).

123 See Appendix One; the exceptions are And 312, 841a, El 616, ChristB 745, Phoen 25, Rid 15.4 .

124 ،...hung around with icicles; hail flew in showers; there I heard nothing except the roar of the sea, the ice-cold wave, at times the song of the swan; I took as my entertainment the cry of the gannet and sound of the curlew in place of the laughter of men.'

125 See J. Roberts, C. Kay, L. Grundy, A Thesaurus of Old English in two volumes, King's College London Medieval Studies 11 (London, 1995), vol. 1, pp. 74-5, sections 02.05.10.0105 (Thing heard; Noise, din; Noise, tumult; To resound; Roaring) and note also hlagol 'apt to laugh', gehleeg 'scorn', hlem 'sound' or 'noise', gehleop 'harmonious', hlisa 'sound' or 'rumour', (a)hlowan 'to bellow (again)', (ge)hlyd 'a clamour', hlydan 'to make a noise', hlyrian 'to blow', and other related forms.

${ }^{126}$ R. Quirk, 'Poetic language and Old English Metre', Early English and Norse Studies presented to Hugh Smith in Honour of his Sixtieth Birthday, ed. A. Brown and P. Foote (London, 1963), pp. 150-71. 
also tend to have semantic relations, and Old English is no exception. ${ }^{127}$ A traditional alliterative poetics (with structured emphasis on sound repetition) with a style characterised by apposition (the repetition and variation of key ideas across the alliterating line and the clause) was fertile territory for play with word-initial phonaesthemes. The $h l$ - phonaestheme was developed by the poets-several lexemes of the field are poetic in register (hleopor, hlynn, hlynsian, hlymman) —and exploited by them onomatopoeically in cluster alliteration (along with rhyme) to accentuate ideas of noisy speech and poetic utterance. ${ }^{128}$ I disagree, accordingly, with Stanley's view that 'as far as we can tell, Old English alliterative verse does not use alliteration for onomatopoeic effects'. ${ }^{129}$

Phonaesthetic use of cluster alliteration by the poets is also found quite independently of rhyme. Word-initial gr- opens many words in Old English in the related semantic areas of grimness, grief, anger and violence; ${ }^{130}$ Much of the lexis of this field is poetic (greotan, grorn, gryn) or attested, according to DOE, mainly (forgrindan, grimman), or frequently (gryre and its compounds), or disproportionately frequently ( $\mathrm{gram}$ ) in poetry, or is hapax (wiðgripan). Gris found in cluster alliteration in the corpus outside of Beowulf in contexts conveying these ideas some forty-five times, this being around two-thirds of all alliterative use of this cluster. ${ }^{131}$

${ }^{127}$ See R. W. Westcott, 'Linguistic Iconism', Language 47.2 (1971), 416-28, at 424: 'In most languages, there is greater semantic overlap between forms that sound alike than between forms that do not. In English, this effect is most noticeable in the case of those homophonies, such as alliteration and rhyme, which are poetically formalized'.

${ }^{128}$ Holofernes' laughter and roaring in Judith are added to the mere statement of his drunkenness in the Vulgate source (12.20). The idea of noise in PPs 73.14.2 (hlynnende hlude) is an addition to the Vulgate verse and not evidenced in the Old English psalter glosses; PPs 92.5.2 (hlynsadan hludan) expands upon the idea of noise in the Vulgate and this variation is not followed by any of the psalter glosses apart from The Canterbury Psalter, which in this section follows the text of PPs (see Eadwine's Canterbury Psalter, ed. F. Harsley, EETS os 92 (London, 1889), p. 164: hofæen 7 hlynsæedcen hludœn reordœ).

${ }^{129}$ E. G. Stanley, In the Foreground: 'Beowulf' (Cambridge, 1994), p. 138. On rare, but clear, use of alliteration for onomatopoeic effect in Middle English alliterative poetry, see T. TurvillePetre, The Alliterative Revival (Cambridge, 1977), p. 57.

${ }^{130}$ Note the following words: forgrindan 'to destroy', forgripan 'to overwhelm, destroy', grædig, 'fierce', græf 'the grave', gegræppian 'to seize', gram 'fierce', grama 'anger', granian 'lament', grap 'claw', (ge-)gremman 'to enrage', greotan 'weep', gretan 'weep', gretan 'attack' grimm 'fierce', grimman 'to rage', grimsian 'to rage', (ge-, for-, wið-)gripan 'to clutch', gripe 'grasp', gristbitian 'to gnash the teeth', grorn 'grief', grornian 'to mourn', grymettan 'to rage', grynn 'affliction', gryre 'terror', together with compounds of these and other affixed forms.

${ }^{131}$ Note the following examples outside of Beowulf: GenA 46 grimme: grim, 61 gegremed grymme: grap, 1102a mid grimme gryre, 1275 forgripan: grimme, 2063 gegrind: gripon, GenB 302: gram: grund, 384a grindlas greate, 390a grimme, grundlease, 407a grimman grundas, 793 grcedige: grimman, Ex 330a grimhelma gegrind, Dan 438a of ðam grimman gryre, Sat 258a grimme grundas, 268a gripan to grunde, 700a grip wið pæes grundes, 707a grim grcefhus, And 217a, 951a in gramra gripe, 917a grame grynsmiðas, 1590 gegrind: grund, El 759a grapum gryrefcest, ChristC 970 grimme: grornað, 1003a grcefe grimlice, 1204a grorne: grimman, 1526a on grimne grund, GuthA 375a forgripen gromhydge, 571a pone grimman gryre (interlaced with 569a gromheorte), Phoen 507 forgripeð: grcedig, Jul 215a of gromra gripe, 596 grennade ond gristbitade...598a grymetade, Max I 51 grimmum: grome, 148 gryre: grœf, Rim 49 greteð: grorn, 66 gromtorn: grœf, 71 grce: grimme, Ruin 14a grimme gegrunden, Rid 84.3a grimme grymetað, PPs 65.10.1 grame: gryne, 68.24.3 forgripe: gramhicgende, 
The Beowulf-poet, above all, makes great play with it in cluster alliteration: $g r$ - is the commonest cluster in cluster alliteration in the poem, ${ }^{132}$ and in all twenty-two occurrences of alliteration on $\mathrm{gr}$ - in Beowulf at least one lexical item is from this group. All but three of these twenty-two lines associate this lexeme with monsters. ${ }^{133}$ Twelve of the forty-two lines containing Grendel's name display cluster alliteration, and all the alliterating words in them opening with $g r$ - are from this word group. ${ }^{134}$ Yet words beginning with $g r$ - form less than one tenth of Old English words beginning with $g$-, so that the poet had plenty of other lexical options, which, in the event, he chose to disregard. The alliterative focus has been selected by the poet for its phonaesthetic felicity. 'Grendel' may, or may not, be a name etymologically related to this field of words, ${ }^{135}$ but from the outset the monster is associated with it:

$$
\text { wæs se grimma gæst Grendel haten [1. 102] }
$$

Both he and his Mother are grim ond grcedig (121a, 1499a), ${ }^{136}$ a phrase which does not appear elsewhere in the corpus, and which may be an adaptation of the attested formula gifre ond grcedig. ${ }^{137}$ Hrothgar laments the loss of his men to Grendel's terror (478a on Grendles gryre, 930a grynna eet Grendle) ${ }^{138}$ and hopes that Beowulf will overcome it (384a wið Grendles gryre); Grendel's Mother too is terrifying, albeit less so than him (1282 Grendles modor: wæes se gryre lcessa). Beowulf speaks of his crushing of the sea monsters and implies that this makes him the right man to take on Grendel (424 forgrand gramum...Grendel). Unferth counters that Beowulf's experience of grim battle will not help him with the monster (527 grimre: Grendles). Beowulf responds that Grendel's terrifying deeds would not have happened if Unferth were a real man (591 Grendel: gryra). Grendel's claw that has killed so many is hung up in Heorot (836a Grendles grape). His Mother claws the hero with grimman grapum (1542a); Beowulf tells Hygelac that she was a terrifying grim guardian of the deep (2136 grimne gryrelicne grundhyrde) and later speaks to his men of how he might grapple with the dragon as he did against Grendel (2521 wiðgripan: Grendle). ${ }^{139}$ Finally, the dragon too is a grim terror (3041a grimlic gryrefah), although, with Grendel gone, use of the cluster fades away in the last section of the poem. This list does not exhaust the examples of the poet's use of this phonaestheme in cluster alliteration with reference to monsters, but is sufficient to show his primary interest in

77.63.3 begrette: grame, 105. 20. 4 granedan: grame, 126.6.4 greteð: grame, 140.11.1 gryne: grame, Met 3.1 grimmum: grundleasum, MSol II.378a grimme greotan, MCharm 11.3a wið pane grymma gryre. In continued alliteration, note too PPs 103.20.2-3 grymetigað/grcedigum, 123.6.3-7.1 grames: gryne, grin: grame (with chiasmus); with enjambed alliteration, Sat 31-2 grund/ gredige, PPS 56.7.1-2 grine/grame, JDay II 189-90 grunde/grimmum; in crossed alliteration, Sat 454 grund: -gryre. See Appendix One for the twenty-one occurrences of grused outside of these semantic fields in poems other than Beowulf.

${ }^{132}$ See Appendix One. Alliteration on $g$ - is also commoner in Beo than in most Old English poems.

133 These three being at ll. 334 (of the armour of the Geats), 765 (of Beowulf in the fight with Grendel, possibly with some idea of reversal, or the biter bit), and 1148 (in the Finn episode).

${ }^{134}$ At 102, 384, 424, 478, 483, 527, 591, 836, 930, 1282, 2521, and 1775 (a metathesised form).

${ }^{135}$ For the various critical suggestions, see Beowulf, ed. Fulk, pp. 467-8.

${ }^{136}$ Line 1499a is also linked in interlace with 1501a grap.

${ }^{137}$ Used at GenA 793a, Sat 32a, 191a, Soul I 74a (and II 69a), Sea 62a, Rid 84.30a.

138 The uniquely attested metathesis in 1. 930a (grynna<gyrnna) is perhaps phonaesthetically motivated.

${ }^{139}$ For discussion of the alliterative collocation of Grendel with $g u ð$, see M. Reinhard, On the Semantic Relevance of the Alliterative Collocations in 'Beowulf', Schweizer Anglistische Arbeiten 92 (Bern, 1976), pp. 57-8. 
it as a vehicle for the characterisation of the monstrous, especially of the Grendel-kin: one particular consonant cluster, connotative of horror and misery, resounds again and again at relevant moments in the poem. ${ }^{140}$ We may think of this as the Beowulfian equivalent of a modern filmic sound effect. ${ }^{141}$

Further evidence of poetic individuality in the use of a phonaestheme is provided by The Battle of Maldon. About 7\% of simplexes in Old English which begin with $f$ - open with $f l$ and more than a third of these have senses denoting, or related to, motion through air or water (including all the etymons of Modern English flee, flight, float, flow, flutter, fly, etc.). ${ }^{142}$ Wordinitial $f l$ - does not appear to have been exploited very much by the poets for artistic effect and this semantic field is devoid of poetic simplexes, ${ }^{143}$ but of the twenty-three occurrences of cluster alliteration on $\mathrm{fl}$ - in the corpus (excluding Maldon), eighteen display at least two words from this field. ${ }^{144}$ As the subject matter of The Battle of Maldon includes Viking seafarers and seafaring (flot, flota), the movement of the tides around Northey Island (flod, flowan), a battle with showers of arrows and spears (flan, fleogan, flyht), and the flight of the cowardly AngloSaxons (fleam, fleon), it is not surprising that a number of these words occur in the poem: all of the words in the poem that begin with $f l$ - are from this lexical field, and alliteration on $f$-is commoner than in any other Old English poem. But the poet chooses also to link these words together in a cascade of cluster alliteration (lines 70-3):

Ne mihte hyra ænig oprum derian, buton hwa purh flanes flyht fyl gename.

Se flod ut gewat; pa flotan stodon gearowe,

${ }^{140}$ See also 483 Grendles: gryrum, 555a grim on grape.

141 The effect continues to appear in later alliterative poetry. See, for example, The Soul's Address to the Body: The Worcester Fragments, ed. D. Moffat (East Lansing, 1987), where four out of the five lines containing stressed words opening with this cluster alliterate on the cluster and most of the words are from this same semantic field (at ll. B13, C18, D7, 33). The exception (B34) casts doubt on Moffat's view (p. 28), that $g r$ - alliteration in this text should be viewed in the same light as st- alliteration, i.e. as part of the alliterative rules. In late Middle English alliterative works, note also lines such as Destruction of Troy 938 Gryppet a grym toole, gyrde of his hede, and Morte Arthure 1369 He gryppes hym a grete spere and graythely hym hittez, etc.

${ }^{142}$ Note the following: flacor 'flying of arrows', flan 'arrow', fleam 'flight', fledan 'to flow', fleogan 'to move quickly', fleoge 'fly', fleon 'to put to flight', fleotan 'to float', flewsa 'flux', flicerian 'flutter', geflien 'to expel', flieman 'to put to flight', fliema 'outlaw', flod 'flowing water', flogettan 'fluctuate', flogeba 'liquid', flot 'sea', flotian 'float', flota 'sailor', floterian 'to float', flowan 'to flow', flugol 'flying', flycgan 'to put to flight', flyge 'flying', flyht 'flight'. On the Modern English [fl] phonaestheme, see L. Bloomfield, Language (New York, NY, 1933), pp. 245-6.

${ }^{143}$ Certain other consonant cluster phonaesthemes also show no, or very little, sign of poetic exploitation: $d w$-, for example, heads a group of words denoting 'error' or 'confusion', but there is very little use of these in cluster alliteration (only GenA 23a and Jul 368) and there are no poetic words in this group.

144 See Sat 111 on flyge...on flyhte, And 1546 flugon: flod and 1573 fleow: flod, ChristB 676a flacor flangeweorc, GuthB 1144a flacor flanpracu, OrW 85a flod wið flode, Rim 47 flyhtum toflowen: flah, 72 flean: flanhred, Rid 10.2a flode underflowen, 74.3 fleah: flode, Beo 542 flodypum: fleotan, Jud 221 fleogan: flana, PPs 104.27.3 fleohcynnes: flugan, Brun 32 flotan: geflemed, MCharm 4.11a fleogende flane, and in enjambed alliteration ChristC 984-5 fleowan/ flodas, Rid 3.56-7 fleogan/flan, JDay I 1-2 floweð/flod. 
wicinga fela, wiges georne. $^{145}$

Continued alliteration on $f$ - where all the alliterations across two or more lines fall on the cluster $\mathrm{fl}$ - is nowhere found in the poetic corpus; elsewhere there are but three places where two alliterations (out of four or five) in two consecutive lines fall on fl-. ${ }^{146}$ This passage in Maldon is the only point where all but one of five consecutive alliterations on $f$ - fall on $f l$-, with the other also showing an echoing consonance (71b fyl) which is picked up again in 73a fela. A number of the poem's translators and editors close a paragraph with the flight of the arrow in line 71 and begin a new one with the ebbing of the tide at the start of line 72, sensing, in part no doubt rightly, that a new stage in the action is beginning at this point. ${ }^{147}$ The poet's alliterative practice, however, suggests that this is mistaken, or, at least, too crude a dismembering of his meaning. The flight of the hawk (1l. 7-8) and the fall of Byrhtnoð's sword (1l. 166-7) both show that this poet is interested in physical movements as images of turning points and of shifts of fortune. In similar fashion here, the poet links the chance flight of an arrow and the flowing of the tide with the impending advance of the enemy force over the ford. In the prose meaning of this passage, the tide is retreating and battle can commence; in the poetic sense, there is also a grim foreboding as forces beyond the control of the Anglo-Saxons move against them. These three harbingers of death (flanes flyht, ${ }^{148}$ flod, flotan) are joined alliteratively and phonaesthetically. The usefulness to alliterative poets of synonyms or near synonyms for common ideas beginning with different sounds has long been recognised in Old English and Middle English critical studies. ${ }^{149}$ That words from the same, or from closely related semantic fields, beginning with the same sound might also have been useful to them has not. ${ }^{150}$

145 'None of them was able to harm another unless someone took his death from the flight of an arrow. The flood tide went out. The seafarers were standing ready, many Vikings eager for war.' The translation is from Bradley, Anglo-Saxon Poetry, p. 521.

${ }^{146}$ At Rid 40.77-8 (flode: flinte, and cf. Rid 3.19a), Jud 220-1 (fleogan: flane- 221), Brun 36-7 (flod: fleame, but note also 35a with non-alliterating flot).

${ }^{147}$ As well as Bradley, see, for example, the translations by G. Bone, Anglo-Saxon Poetry: An Essay with Specimen Translations in Verse (Oxford, 1944), p. 29; C. B. Hieatt, 'Beowulf' and Other Old English Poems (Toronto, 1983), p. 111; B. Raffel, Poems and Prose from the Old English (New Haven, CT, 1998), p. 45. Two editions do likewise: Seven Old English Poems, ed. J. C. Pope (Indianapolis, IN, 1966), p. 18, Bright's Old English Grammar and Reader, ed. F. G. Cassidy and R. N. Ringler (New York, NY, 1971), p. 363. 'Leoð': Six Old English Poems-A Handbook, ed. B. J. Muir (New York, NY, 1989), p. 89 has a new paragraph beginning at $1.72 \mathrm{~b}$.

${ }^{148}$ Note that gename in line 71 is subjunctive, not indicative: we are not told that soldiers were killed by arrows, but rather that, should someone be harmed, then it could only be by such an action.

${ }^{149}$ See, for example, M. Borroff, Sir Gawain and the Green: a Stylistic and Metrical Study, YSE 152 (New Haven, CT, 1962), p. 57 on the subject of rank: 'The traditional groups of words for the expression of important meanings, each word beginning with a different letter, form an apparatus of obvious value for the practicing poet.').

${ }^{150}$ Other clusters in the poetry with a claim to be phonaesthemes remain to be studied. Sl-, for example, opens fairly numerous Old English words denoting sleep, sloth and slaughter and all the use of such cluster alliteration in the poetry plays with one or more of these ideas: sleep in GuthA 343a (slæpa sluman), slaughter in Beo 2398a (sliðra geslyhta) and PPs 102.18.4 (ofslegene: slipe), sleep and slaughter in Beo 741 (slependne: slat), 1581 (sloh: slepende), and Jud 247 (slege-: slæpe), sleep and sloth in JDay II 240-1 (slæp/ sleac mid sluman: slincan, with 


\section{b. ii Consonance}

If fyl does participate in the sound effect of the fl-alliteration of Maldon lines 70-3, then it is worth enquiring whether consonance resonates beyond clusters elsewhere in this poem. The following are the lines from Maldon in which two stresses participate in cluster alliteration and a third maintains the functional alliteration, but without the cluster:

$\begin{array}{ll}39 & \text { feoh wið freode, and niman frið æt us } \\ 71 & \text { buton hwa purh flanes flyht fyl gename } \\ 106 & \text { pær wearð hream ahafen; hremmas wundon } \\ 115 & \text { his swuster sunu, swiðe forheawen } \\ 137 & \text { and pæt spere sprengde, pæt hit sprang ongean } \\ 140 & \text { Frod wæs se fyrdrinc; he let his francan wadan } \\ 163 & \text { brad and brunecg, and on pa byrnan sloh } \\ 179 & \text { mid fripe ferian. Ic eom frymdi to pe } \\ 242 & \text { scyldburh tobrocen. Abreoðe his angin } \\ 295 & \text { Đa wearð borda gebræc. Brimmen wodon }\end{array}$

All, apart from line $115,{ }^{151}$ show alliteration on clusters with liquids as second elements; seven of these nine lines show the third alliterating item of the line sharing consonance with the alliterating clusters (fyl, spere, fyrd-, byrnan, ferian, -burh, borda), a proportion far beyond chance. In fact, this poet uses consonance of this sort more frequently than any other Old English poet: it is found in nearly half of all the lines with cluster alliteration. ${ }^{152}$ Six of these involve $r$-clusters. ${ }^{153}$ In four of these six, noises of battle are alluded to (the flight of an arrow, the shivering of a spear, the breaking of the shield-wall, the crashing of shields) so that the appeal to the ear is at least partly mimetic, but the superfluity of similar sounds perhaps also suggests an interest in the patterning of sound for the sake of it, or a love of language. Line 137, quoted above, is especially unusual in being the only line in Old English poetry alliterating on the cluster spr-. Line 9 shows the only alliteration in the corpus on the cluster $c n$ (oncnawan: cniht). This poet likes tying together words of similar sound and sense, not just flod and flota (1. 72), and sprengan and springan (l. 137), but also freod and frið 'peace' (1. 39), wig and wiga (l. 75a, 235) 'war' and 'warrior', and wiga and wigend 'warrior' (1. 302) —and also words of similar sound and quite different senses (18a rad and ræedde, 25 stcð and stið-, 99 land and lind, 106 hream and hremm, etc). He likes playing with name elements and the words they come from (151 ðone cepelan Apelredes pegen, 187 Godric...pone godan forlet, 237 god swurd...Godric, 280 Aperic, cepele gefera). ${ }^{154}$ Most of this playfulness necessarily involves consonance of sound across the stem syllable and instances proliferate in the poem.

enjambed alliteration). Sleep and sloth are semantically related; sleep's connection with death is metaphorical (e.g. the sleep of death), sloth's with death proverbial (see, for example, $A$ Proverb from Winfrid's Time).

${ }^{151}$ No line in the corpus shows consonance of $s w$ - and $s-w$. See Appendix One.

152 Seven out of fifteen lines in total, but four $(9,65,72,299)$ show alliteration only on the two clusters, and one alliterates on the cluster in three positions (118).

${ }^{153}$ Note that $r$ is the consonant most involved in metathesis, the sound change by which the consonant 'moves from immediately before a vowel to immediately after it' (Campbell, Grammar, §459). The change appears to have involved /r/, alone amongst Old English consonants, becoming syllabic: see S. Rot, Old English, $2^{\text {nd }}$ ed. (Budapest, 1986), p. 157.

154 See further on this M. Griffith, 'Alliterative Licence and the Rhetorical Use of Proper Names in The Battle of Maldon', Prosody and Poetics in the Early Middle Ages: Essays in Honour of C.B.Hieatt, ed. M. J. Toswell (Toronto, 1995), pp. 60-79. 
$B$ - alliteration, for example, is commoner here than in any other Old English poem-there are more than thirty lines of it-and this is because of the poet's fondness for a network of words related by $r$-consonance that unite the hero, the men and weapons (especially Byrhtnoð, beornas, bord, and gebeorge) and which account for about half of this alliteration. ${ }^{155}$

Stylised use of $l$-consonance is also in evidence. The poet's fascination with the dramatic is seen with the fall of the hero's sword in line 166, which prompts an elaborate ordering of sounds:

\section{Feoll pa to foldan fealohilte swurd}

The final word of the line, swurd, lacks both formal and supererogatory alliteration, so that the pattern of the ornament parallels that of the formal structure.. It marks a turning point in the narrative; not the only one, for the ebbing of the tide, the flight of the cowards and the shattering of the shield-wall are all critical moments, but the hero can fight no more and the fall of his sword signals his end, so that this is the most moving of these moments. By proleptic metonym, Byrhtnoth's sword stands for him (for it is usually men who 'fall to the ground' in the poetry), ${ }^{156}$ and, by synecdoche, his fall stands for the larger defeat. The combination of normal alliteration and of supererogatory consonance binds together the golden hilt (with its dual associations of beauty and of transience), ${ }^{157}$ the earth (with its dual associations of homeland and of death), and the movement of the one to the other. A sort of alliterative interlace reinforces the striking visual image. There is also a poignant ironic echo of Byrhtnoth's sterling words to the Viking messenger - he and his men will defend their people and land, and the heathens will fall in battle:

\section{folc and foldan. Feallan sceolon line 54}

Almost exactly the same structure of $l$-consonance in a line of $f$-alliteration is visible, ${ }^{158}$ and only here and in line 166 in Maldon is there collocation of feallan and folde. The hero's words prove untrue and have redounded on him. Finally, at one point in the poem it is even possible that $l$-consonance has moved beyond ornament and become alliteratively functional:

\section{Ælfnoð and Wulmær begen lagon line 183}

The line either lacks alliteration altogether, or post-vocalic -l- in the two names of the a-verse alliterates with the finite verb in fourth position: word non-initial and verse non-initial alliteration may bind the line together. In another poem, where consonance was less prominent, this would seem highly improbable, but not so in this poem. ${ }^{159}$ Maldon is more frequently

155 See lines 15a, 17, 42, 62, 92, 101, 110-11, 131, 144, 162-3, 245, 257, 270, 277, 284, 295, 309.

${ }^{156}$ Compare Sat 531a feollon on foldan, And 918a feoll pa to foldan, Fort 26a feallep on foldan, Beo 2975a feoll on foldan, and, with animation of the inanimate, Dream 43a feallan to foldan sceatum. The waters of baptism, however, feollon to foldan in Sat 544a.

${ }^{157}$ See The Battle of Maldon, ed. D. G. Scragg (Manchester, 1981), p. 78, who rightly points to the punning associations of fealo here.

${ }^{158}$ And no other line in the poem exactly repeats the structure, although line 227 comes close. ${ }^{159}$ For this suggestion, see The Guthlac Poems of the Exeter Book, ed. J. Roberts (Oxford, 1979), p. 176, where she compares GuthB 1234 bi me lifgendum. Huru ic nolde sylf - which, she suggests, shows functional consonance. If this view is correct then Mald 183 should be added to the list, below, of lines in non-traditional verse with postponed alliteration. 
criticised for its 'glaring faults of defective alliteration', ${ }^{160}$ than it is praised for its alliterative innovativeness, but there is freshness in this exploitation of clusters and of consonance. Both these enhancements of the alliterative style were to be picked up by Middle English alliterative poets, ${ }^{161}$ and are used by them so frequently that they come to figure in parodic imitations of the alliterative line: gle glo glas glum and rum ram ruf. ${ }^{162}$

\section{c. Continued alliteration}

Nothing in the alliterative or metrical rules of the poetry, as far as we know, forbids continuance of the same alliterative sound from one line to the next. Opinions as to its deliberateness have varied. On the one hand, Kaluza thought it a feature that was eschewed:

'Generally the use of the same alliterating sound in two or more consecutive verses is avoided... [but where unavoidable] generally the verses are separated by a pause and belong to separate paragraphs, so that the sameness of the alliteration does not strike the ear'. ${ }^{163}$

His examples are from Beowulf: lines 63-4, 216-17 and 606-7; but the poem contains a greater number of examples where the lines do not belong to separate paragraphs and many with strong syntactic enjambment between the lines. ${ }^{164}$ Le Page broadly agrees Kaluza, regarding it as a 'fact' that:

'apart from double alliteration, extra-alliteration has no stylistic significance in Old English poetry; rather, that lack of it indicates a higher degree of conscious artistry, and that in this respect Cynewulf was not as accomplished as the Beowulf poet'. ${ }^{165}$

Continued alliteration is indeed more frequent in Cynewulf, in late poetry, and in texts that are translations (presumably as a licence), and appears more sparingly in Exodus, Daniel, Guthlac $A,{ }^{166}$ and Beowulf-poems generally thought to be early. ${ }^{167}$ Genesis $A$, a biblical paraphrase,

${ }^{160}$ Bliss, Metre, p. 101, and Maldon, ed. Scragg, p. 41: 'the poet falls far short of some of his predecessors in terms of technical skill and in imaginative use of language'.

${ }^{161}$ Although Maldon is unusual in its substantial and varied use of consonance, it is not unique in the corpus in using this device. Many of the poets, for example, play with $c n-/ c-n$ : of the hundred or so lines in the corpus that have an alliterating stress opening with $c n-$, half show alliteration with $c-n$, despite the very many other options that the lexicon offered the poets.

162 See, respectively, Ludus Coventrice or The Plaie called Corpus Christi, Cotton MS. Vespasian D. VIII, ed. K. S. Block, EETS es 120 (London, 1922), p. 149, 'The Adoration of the Shepherds', ii pastor, l. 85, and The Riverside Chaucer, ed. L. Benson (Boston, 1987), p. 287, 'The Parson's Prologue', 1. 43. Overuse of these devices in Middle English alliterative poetry perhaps eroded the specific kinds of meaning outlined here for their occasional (but systematic) rhetorical use in Old English.

${ }^{163}$ M. Kaluza, A Short History of English Versification: From the Earliest Times to the Present Day, trans. A. C. Dunstan (New York, NY, 1911), pp. 123-4.

${ }^{164}$ With notable enjambment at ll. 403-4, 489-90, 644-5, 871-2, 898-9, 919-20, 969-70, $1205-$ 6, 1239-40, 1368-9, 1552-3, 1632-3, 1824-5, 2011-12, 2032-3, 2043-4, 2259-60, 2285-6, 29878, 3004-5.

165 'R. B. Le Page, 'Alliterative Patterns as a Test of Style in Old English Poetry', JEGP 58 (1959), 434-41, at 439. Both Lewis and Le Page in their comments refer to a wider range of alliteration across lines than I deal with in this section.

${ }^{166}$ See Guthlac, ed. Roberts, p. 63: 'Successive alliteration...occurs about three times more often in Guthlac B than in Guthlac A'.

${ }^{167}$ See Appendices Two and Six for full details. As consonantal and vocalic alliteration behave in some ways differently in the poetry, these are kept apart in the lists. K. R. Grinda also notes 
but also, supposedly, an early poem, belongs to the former group, so that date of composition is not the sole determining factor of the rate of use. Judith and The Battle of Maldon, both late but accomplished poems, exhibit more continued alliteration than Cynewulf's Elene. ${ }^{168}$ On the other hand, Lewis assumes it to be purposeful:

'Little more need be said here to demonstrate that such instances are not accidental or nonfunctional. In a tradition that is plurilinear in impulse and that is carried on by literate, sensitive poets, and in which alliteration is the single most prominent signal of item correspondence, it would be strange if such plurilinear alliteration did not appear'. ${ }^{169}$

Though acknowledging its rarity, Oakden also regards it as 'nevertheless, a conscious device'. ${ }^{170}$ Schipper thinks it emphatic, at least in Judith. ${ }^{171}$ Bliss has demonstrated that on occasion some of the poets used a normal long line followed by a short line of a single verse, with the two often united by continued alliteration. ${ }^{172}$ If the poets were alert to continued alliteration in this circumstance, it seems unlikely that they were generally insensitive to its use elsewhere. Its artistic deployment can be seen in Cadmon's Hymn:

Nu sculon herigean heofonrices weard,
meotodes meahte and his modgepanc,
weorc wuldorfæder, swa he wundra gehwæs,
ece drihten, or onstealde.
He ærest sceop eorðan/ylda bearnum,
heofon to hrofe, halig scyppend;
pa middangeard moncynnes weard,
ece drihten, æefter teode
firum foldan, frea ælmihtig. ${ }^{173}$

the sparing us of consecutive alliteration in these poems: 'Pigeon-holing Old English Poetry: Some Criteria of Metrical Style’, Anglia 102 (1984), 305-22, at 313.

${ }^{168}$ One late Middle English poem makes very great use of it: 75\% of lines in Morte Arthure participate in continued alliteration (see Y. Moriya, 'Identical Alliteration in The Alliterative Morte Arthure', ELN 38 (2000), 1-16). For further discussion of the distribution of continued alliteration in Old English by poem, see Griffith, 'Method', pp. 40-4: continued vocalic alliteration in the corpus is distributed differently from continued consonant alliteration.

${ }^{169}$ R. A. Lewis, 'Plurilinear Alliteration in Old English Poetry', Texas Studies in Literature and Language 16 (1975), 589-602, at 599.

170 J. P. Oakden, Alliterative Poetry in Middle English: the Dialectal and Metrical Survey (Manchester, 1930), p. 155.

${ }^{171}$ J. Schipper, A History of English Versification (Oxford, 1910), p. 50, Schipper is, perhaps, following the view of Cook: see Judith, An Old English Epic Fragment, ed. A. S. Cook (Boston, 1904), p. xxiv.

${ }^{172}$ A. J. Bliss, 'Single Half-Lines in Old English Poetry', N\&Q 216 (1971), 442-9; Bliss concludes: 'Old English gnomic verse is characterised by the sporadic use of short lines; these often have double alliteration, but continue the alliteration of the preceding line much more frequently than in Old Norse... a study of a single poetical codex shows a substantial number of short lines to which neither sense nor syntax requires any addition. More than half of these short lines have either double alliteration or continued alliteration' (at pp. 448-9).

173 'Now we must praise the Guardian of heaven, the Maker's might and His mind's intent, the glorious Father's work, as for each wonder, He eternal Lord, established the beginning. He, holy Creator, at the first fashioned heaven as a roof to the children of men; He, eternal Lord, the Guardian of mankind, almighty King, afterwards adorned this middle-earth, the world, for 
Bede records that Cædmon's poetic art was not the product of human teaching but rather of divine inspiration. ${ }^{174}$ His poems were, accordingly, 'extremely delightful and moving', thereby inspiring many 'to long for the heavenly life'; of other vernacular poets 'none could compare with him'; and after he recites the Hymn in front of learned men, 'it seemed clear to all of them that the Lord had granted him heavenly grace'. ${ }^{175}$ And yet this poem contains continued alliteration on vowels in lines 4-5-and in so short a poem this is a feature of prominence. The authority conferred on the use of continued alliteration could not have been greater. If this feature was thought to be unpleasing, why was the poem regarded as beautiful, and why were 'learned men' convinced of its divine origin? Even if we accept the argument that the poem is not in fact Cædmon's song but instead a rendition of Bede's Latin, ${ }^{176}$ this argument is not substantially affected, for from an early date it was believed to be the original, ${ }^{177}$ and was preserved in multiple copies of the History. No attempt was made by copyists to emend away the alliteration. Whether eorðan bearnum, an etymology of Adam's name, ${ }^{178}$ is a learned substitution for an original formula ylda bearnum, or the poetic cliché represents scribal normalising of the unusual phrase 'the sons of earth', the vocalic alliteration remains. Cædmon's use of continued alliteration gave this feature, at least from the time of its inclusion in the History, divine imprimatur. ${ }^{179}$

What purpose, we must then ask, does this continued alliteration serve? Cædmon is instructed to sing of creation (Canta...principium creaturarum), ${ }^{180}$ and the resulting Hymn, after an opening injunction for creation to praise its Creator, is a free adaptation of the first

men.' The translation is from L. J. Rodrigues, An Anglo-Saxon Verse Miscellany (Felinfach, 1997), p. 21.

174 'Namque ipse non ab hominibus neque per hominem institutus canendi artem didicit, sed diuinitus adiutus gratis canendi donum accepit' ('For he did not learn the art of poetry from men nor through a man but he received the gift of poetry freely by the grace of God.'), Bede's Ecclesiastical History of the English People, ed. B. Colgrave and R. A. B Mynors (Oxford, 1969), pp. 414-15.

${ }^{175}$ Ecclesiastical History, ed. Colgrave and Mynors, p. 417.

${ }^{176}$ See D. Dumville, 'Beowulf and the Celtic World: the Uses of Evidence', Traditio 37 (1981), 109-60, at 148: 'the Old English is at least as likely to be a poetic rendering of Bede's Latin as the source of his words; otherwise we could have expected more of the poem to have been given by the person who added these nine lines at the end of the Moore manuscript'. How likely is it, however, that Christian Anglo-Saxons would have lost a poem in their own language thought to be divinely inspired?

${ }^{177}$ It is found in the Moore MS (CUL Kk. 5. 16) of the History, one 'almost contemporary with Bede' (see Three Northumbrian Poems, ed. A. H. Smith (London, 1933), pp. 12-13). After the text of the poem, the manuscript continues with the statement that 'Primo cantauit Caedmon istud carmen' 'thereby suggesting that the attribution of the Old English text to Cædmon himself was traditional by as early as within a few years of Bede's death' (see A. Orchard, 'Poetic inspiration and prosaic translation: The making of Credmon's Hymn', Studies in English Language and Literature: 'Doubt wisely', Papers in honour of E. G. Stanley, ed. M. J. Toswell and E. M. Tyler (London, 1996), pp. 402-22, at 411).

${ }^{178}$ See, for this suggestion, J. Golden, 'An Onomastic Allusion in Cædmon’s Hymn', NM 70 (1969), 627-9.

179 As G. Shepherd puts it: 'without doubt, Cædmon's gift, this gift recognized as of a divine origin was powerful in establishing, as Bede indicates, the Bibelpoetik of Anglo-Saxon verse': 'The Prophetic Cædmon', RES 5 (1954), 113-22, at 122.

${ }^{180}$ Ecclesiastical History, ed. Colgrave and Mynors, p. 416. 
verse of Genesis: in principio creauit deus celum et terram. Its first three key ideas are referenced in lines four and five of the Hymn: the beginning (4b or), the initial act of creation (5a cerest sceop) and God (4a ece drihten). A syntactic division, however, at the end of the fourth line divides these ideas across two clauses and two lines, with the beginning separated from the divine action in a way not sanctioned by the Biblical verse. ${ }^{181}$ The alliteration, however, continues across the divide, binding together phonetically ideas which are bound together syntactically and theologically in the first verse of the Vulgate. The sense of the poem is more than the sum of its parts and its sounds contribute to the sense. As in the passage of continued alliteration from Maldon (ll. 71-2, above, which similarly run across a syntactic boundary), meaning is communicated by style.

The imitation of one poet's work by another is very rarely attested with any certainty in the Old English poetic corpus. One strong candidate, however, is the opening of Genesis A, lines 1-8 :

Us is riht micel ðæt we rodera weard,
wereda wuldorcining, wordum herigen,
modum lufien! He is mægna sped,
heafod ealra heahgesceafta,
frea ælmihtig. Næs him fruma æfre,
or geworden, ne nu ende cymp
ecean drihtnes, ac he bið a rice
ofer heofenstolas... 182

Doane rightly calls this 'a "hymn" in the Cædmonian manner, contemplating the power and eternity of the Creator [which] corresponds in function and statement to lines 1-4 of Hymn'. ${ }^{183}$ Both openings insist on the duty of the created to praise the Creator, probably inspired in both cases by the Preface to the Canon of the Mass. ${ }^{184}$ There is some shared diction as well as shared theme. The strongest verbal echo is in lines 6-7 (or...ecean drihtnes), which also display continued vocalic alliteration. That both these deeply serious religious poets, whilst celebrating the Creation, lapsed accidentally and coincidentally into an unartistic kind of extra alliteration that they ought better to have avoided is difficult to believe. The alliterative supererogation here functions in a manner analogous to its operation in the Hymn, linking key ideas by sound - the eternity (ecean, a) of the Godhead as alpha (or) and omega (ende). ${ }^{185}$ If this is not a homage to the style of the Hymn, then another Old English poet is treating the same ideas in exactly the same stylistic fashion.

${ }^{181}$ Note, for example, the translation of C. Hieatt, which begins a new paragraph with line 5 of the Hymn (C. B. Hieatt Beowulf and Other Old English Poems (Toronto, 1983), p. 87).

182 'It is very right for us that we should praise with words the guardian of the heavens, the glorious king of hosts, should love him in our minds. He is abundant in powers, head of all lofty creatures, the Lord almighty. There never was a beginning for him, nor an origin brought about, nor presently will come and end of the eternal Lord, but forever he will be sovereign over the thrones of heaven.' The translation is from Old Testament Narratives, ed. and trans. Anlezark, p. 3.

${ }^{183}$ Genesis A: A New Edition, Revised, ed. A. N. Doane (Tempe, AZ, 2013), p. 287.

${ }^{184}$ Vere dignum et justum est...nos tibi...gratias agree: 'It is truly fitting and proper for us to give praise to you'; see L. Michel, 'Genesis A and the Praefatio', MLN 62 (1947), 545-50.

${ }^{185}$ See Rev 1.8. 
Where the continued alliteration falls upon one of the uncommon alliterating sounds, the argument for rhetorical use is, à priori, stronger. The editor of Juliana views the poem's style as 'unrelieved by any emotional or rhetorical emphasis', and, similarly, Calder, thinks it 'as unrelentingly simple as the heroine herself' ${ }^{186}$ But this is not always the case. In a passage apparently added by Cynewulf to his source, ${ }^{187}$ the devil, before he confesses his sins against mankind as commanded by the heroine (ll. 456-60), first acknowledges the power of her speech and the consequent necessity for him to confess (lines 461-6):

Nu ic pæt gehyre purh pinne hleoporcwide,
pæt ic nyde sceal, nipa gebæded,
mod meldian, swa pu me beodest,
preaned polian; is peos prag ful strong,
preat ormæte. Ic sceal pinga gehwylc
polian ond pafian on pinne dom...

The declaration belongs to a type of heroic utterance in the poetry isolated by Shippey and termed by him the speech of 'submission and recognition' which occurs 'at the moment of pearf [necessity]' when speakers 'declare that they have reached the limit of endurance'. ${ }^{189}$ Examples are often additions to the sources and are evidence, in his eyes, of the tendency of the poets to re-cast foreign narratives in a shared traditional form. ${ }^{190}$ Cynewulf gives the convention idiosyncratic shape. The devil responds to Juliana's rhetoric (pinne hleoporcwide) with an oratory of his own, expressing his suffering in a sequence of three lines of alliteration on $p$ - (ll. 464-6). The unusualness of this has not interested the editors of the poem who offer no comment on these lines. ${ }^{191}$ No alliteration on one consonant extends beyond three consecutive lines in the corpus, and consonant alliteration continuing for three lines is very rare: indeed, outside of The Metrical Psalms, where it occurs with some greater freedom, ${ }^{192}$

${ }^{186}$ See Cynewulf's 'Juliana', rev. ed. R. Woolf (Exeter 1977), p. 17, and D. G. Calder, Cynewulf (Boston, MA, 1981), p. 156.

${ }^{187}$ Cynewulf's exact source is not known, but, according to 'Juliana', ed. Woolf, p. 13, was 'closely related' to the version printed in Acta Sanctorum, Februarius, Tom. II, ed. J. Bollandus and G. Henschenius (Antwerp, 1658), pp. 873-7 and translated by D. G. Calder and M. J. B. Allen, Sources and Analogues of Old English Poetry: The Major Latin Texts in Translation (Cambridge, 1976), pp. 121-32 (the relevant section is at p. 128).

188 'Now from your eloquence I can hear that, forced by these afflictions, I must of necessity declare my mind, as you command me, and suffer the pain of punishment. The occasion is extremely violent, the ill-treatment excessive. I must suffer and submit to everything within your jurisdiction...' The translation is from Bradley, Anglo-Saxon Poetry, p. 313.

${ }^{189}$ T. A. Shippey, Old English Verse (London, 1972), p.122. Shippey gives examples at El 426ff, Jud 83-94, Mald 175-80, Jul 695ff, And 1164-7 and 1602-6.

190 Shippey, Verse, pp. 126-7.

${ }^{191}$ In addition to 'Juliana', ed. Woolf, see The Juliana of Cynewulf, ed. W. Strunk (Boston, MA, 1904), and The Old English Poems of Cynewulf, ed. and trans. R. E. Bjork, DOML 23 (Cambridge, MA, 2013).

192 Within psalm verses, it occurs at (with the alliterating sound in brackets): 91.6.4-6 (w-), 101.23.2-4 (w-), 105.9.2-4 (w-), 105.10.2-4 (f-), 118.14.1-3 (w-), 138.18.1-3 (f-). Crossing psalm verses, it appears at: 61.7.3-8.2 (h-), 85.7.3-8.2 (w-), 85.16.3-17.2 (f-), 88.36.2-37.2 (f), 93.15.3-16.2 (s-), 101.17.2-18.1 (h-), 118.141.3-142.2 (s-), 118.151.1-152.1 (w-), 119.5.56.2 (s-), 122.3.5-4.2 (m-), 127.2.3-3.2 (w-), 135.7.2-9.1 (m-). 
there are only sixteen instances apart from this one. ${ }^{193}$ Eight of these sixteen alliterate on $w$-, which is the commonest consonant in alliteration and so the one that was presumably the easiest to elaborate upon, or the likeliest to be continued by chance. ${ }^{194}$ Alliteration on $b$ - across three lines is evidenced nowhere else and this is the rarest sound (from Table One above) to occur in such extended alliteration. Two of these three lines also contain double alliteration, giving a total of eight alliterations in the passage on this uncommon initial sound (rather than the necessary minimum of six, or two per line), so making the feature even more prominent. Cynewulf has his devil express his submission in a unique alliterative barrage (with some play too on the cluster $p r$ - in 464-5: preaned, prag, preat). Repetition of theme and lexis is strongly marked. Within just five lines, the devil complains twice of his need, with the same word (462 nyde, 464 -ned); twice of his punishment, in near homophones (464 prea-, 465 preat 'punishment'); and twice in exactly the same words that he must suffer (462-4 ic...sceal...polian, 465-6 Ic sceal...polian, with the idea again repeated in 466 pafian 'suffer'). In short, the lines display more sound than sense. Phonetic excess intertwines with semantic redundancy to convey a self-pitying grandiloquence in demonic abuse of heroic genre. In the divine use of continued alliteration in the Hymn (and also in Genesis A), there is precision; in this satanic display, there is vacuity.

Although chance alliteration is likelier with the more commonly occurring phonemes, sometimes ornament is clearly the more attractive way of interpreting the evidence we have. Printed as two riddles by ASPR because palaeographically separated in the manuscript, Riddles 68 and 69 are nonetheless better interpreted as one, and are presented as such by various editors:

(68) Ic pa wiht geseah on weg feran; heo wæs wrætlice wundrum gegierwed.

(69) Wundor wearð on wege; wæter wearð to bane. ${ }^{195}$

With the first two lines must be compared the opening of Riddle 36 with which they are nearly identical:

Ic wiht geseah on wege feran, seo wæs wrætlice wundrum gegierwed....

${ }^{193}$ In the following lines (following ASPR), with the alliterating sound and the number of stresses alliterating on that sound given in brackets: GenA 35-7 (w-, 8x), 1014-16 (w-, 9x), 2807-9 (s-, 8x), Sat 524-6 (g-, 6x), And 589-91 (f-, 6x), Soul I 82-4 (w-, 6x, with postponed alliteration in 83b), ChristC 1412-14 (h-, 7x), 1431-3 (m-, 6x), GuthB 1363-5 (w-, 9x), Jul 1679 (g-, 7x), Rid 31.7-9 (f-, 7x), 40.47-9 (w-, 6x), Beo 897-9 (w-, 6x), Mald 95-7 (w-, 9x), MSol II.336-8 (d-, 9x), JDay II 50-2 (w-, 6x).

194 The poetry alliterates on nineteen different sounds, so that the chance of alliteration continued across two lines is one in nineteen, and across three lines 1 in 361 (being 19 squared). The frequency in PPs is, accordingly, slightly greater than by accident, that elsewhere considerably less than chance would suggest. But, as Russom observes of continued alliteration in poetry: 'a linguistic event with such low probability will be noticed' (see G. Russom, The Evolution of Verse Structure in Old and Middle English Poetry From the Earliest Alliterative Poems to Iambic Pentameter, CSML 98 (Cambridge, 2017), p. 7).

195 So, The Riddles of the Exeter Book, ed. F. Tupper (Boston, MA, 1910), p. 48, Old English Riddles, ed. A. J. Wyatt (Boston, MA, 1912), p. 49, The Old English Riddles of the Exeter Book, ed. C. Williamson (Chapel Hill, NC, 1977), p. 106. 
As has rightly been observed, the opening of a riddle (and one that appears to be a formula giving only the most general information about the solution), can hardly function also as an entire riddle, so that, even if ASPR is correct to present 68 and 69 as two separate texts, the first cannot be complete. ${ }^{196}$ Those who argue that the three lines form a single riddle rest their case upon an amphibole. ${ }^{197}$ Wege in 36.1 is dative of the short-stemmed noun 'way' ('I saw on the way a creature travelling'), ${ }^{198}$ and the near identicalness of 68.1 suggests that weg in 68.1 is the same word transposed into the accusative because of the motion indicated by feran (' $\mathrm{I}$ saw a creature travelling on the way'). Wege in 68.3a, if the verse is metrically normal, has, however, a long-stem and so must be the poetic noun wäg 'wave', 'sea' ('A wonder was in the water'). ${ }^{199}$ Retrospectively, then, this form suggests that weg in 68.1 should be re-interpreted as the long-stemmed noun-as, indeed, appears at the start of Riddle 33 Wiht cwom cefter wege wrcetlicu lipan ('A wondrous creature came sailing through the water'), a riddle which shares the same solution as this one, 'Sea ice', 'Drift ice' or 'Iceberg'. The clue that the solution is a marine 'creature', which is given to us at the start of Riddle 33, is, accordingly, at first disguised in Riddle 68. Had the poet in 68.1 used the dative singular form wege (as in 33.1) instead of the accusative, then the re-reading of the form as the long-stemmed noun would not have been possible, as metrical type 2A1a should not occur with anacrusis. ${ }^{200}$ With the uninflected accusative, however, the verse scans normally as type 2C1a, whether weg is short- or longstemmed. Transposition to the accusative is metrically necessary for the punning to work and shows that a vague riddling formula has here been put to unusually precise use. The riddle, however, also displays continued alliteration-all three lines have $w$ - alliteration, this being, accordingly, the eighteenth example of such alliteration in the corpus. Riddle 68, then, is the only poem in the corpus to alliterate throughout on just a single sound, and, if its poet added the third line to a pre-existing riddle-initial formula, as the opening to Riddle 36 suggests, then this can only have been deliberate artifice. The pattern of sound threads together the punning words, in a text which possesses, uniquely in Old English poetry, phonetic unity.

Lexical repetition or word echo runs through these examples of continued alliteration, either by way of poetic imitation in Genesis $A$, or as a means of characterising the satanic in Juliana, or as a product of riddling wit in Riddle 68. In The Battle of Maldon it combines with continued alliteration in a more complex fashion. Vocalic alliteration is continued quite frequently in the poem-in lines 5-6, 51-3, 69-70, 132-3, 206-7, 230-1, 233-4-and this forms a third of all continued alliteration in the poem. ${ }^{201}$ One of these shows alliteration continued unusually over three lines (lines 51-3):

...pæt her stynt unforcuð eorl mid his werode, pe wile gealgean ${ }^{202}$ epel pysne,

\footnotetext{
196 Riddles, ed. Wyatt, p. 113.

${ }^{197}$ See Riddles, ed. Tupper, p. 208, and Riddles, ed. Williamson, pp. 335-6.

198 And similarly Rid 70. 5b be wege stonde. Although Pope regards the form wege here as ambiguously short- or long-stemmed (see J. C. Pope, 'An Unsuspected Lacuna in the Exeter Book', Speculum 49 (1974), 615-22, at 618), if it were long, then the verse would have to scan as 2A1a with anacrusis, which is 'not permissible' (see Bliss, Metre, p. 41).

199 Scan either as metrical type $1 \mathrm{~A} 1 \mathrm{~b}$ or $1 \mathrm{~A} * 1 \mathrm{~b}$ (with wundor either monosyllabic or disyllabic). With a short-stem noun in final position, the verse would have to be type 2E1b which is rare and, probably, anomalous.

${ }^{200}$ See Bliss Metre, pp. 40-2.

${ }^{201}$ Consonant alliteration is continued at lines 21-2, 29-30, 71-2, 81-2, 95-7, 110-11, 148-9, 162-3, 199-200, 259-60, 276-7, 290-1, 302-3.

${ }^{202}$ With gealgean for ealgean or, perhaps, ge-ealgean; see Maldon, ed. Scragg, pp. 71-2.
} 
Æpelredes eard, ealdres mines. ${ }^{203}$

Referring to himself in the third person, Byrhtnoð joins himself with his men as defenders of king and country and the alliteration reinforces this, uniting these salient ideas (eorl, epel, Epelred). Eorl, the main epithet for Byrhtnoð, occurs ten times in the poem and elsewhere is evidenced in continued alliteration three times, in lines 5-6 where the poet notes his rejection of cowardice:

$$
\begin{aligned}
& \text {...Pa pæt Offan mæg ærest onfunde, } \\
& \text { pæt se eorl nolde yrhðo gepolian... }{ }^{204}
\end{aligned}
$$

in lines 132-3, where the resolute nobleman advances against a Viking:

Eode swa anræd eorl to pam ceorle, ægper hyra oðrum yfeles hogode ${ }^{205}$

and in lines 232b-4 when Offa affirms their joint duty to encourage one another now their lord lies dead in the dirt:

$$
\text { nu ure peoden lið, }
$$

eorl on eorðan. Us is eallum pearf

pæt ure æghwylc operne bylde. ${ }^{206}$

At moments where the poet (or his characters) connect the eorl with values of nobility, courage, resoluteness, or the duty of vengeance, supererogatory alliteration is in evidence. Other kinds of extra alliteration also occur in conjunction with the term-at the ominous moment in line 159 when a Viking advances on the wounded Byrhtnoð, there is ornamental crossed alliteration:

\section{Eode pa gesyrwed secg to pam eorle}

And enjambed alliteration once links the hero with his king (lines 202-3a):

pa wearð afeallen pæs folces ealdor, Æpelredes eorl.

Six of the ten occurrences of the word eorl in the poem show it embedded in additional alliteration. A sceptic might observe that, as continued alliteration and lexical repetition are both sporadic throughout the poem, then there must, simply by chance, be some instances where both occur together. And yet, no other word in the poem matches this prominence given to eorl in continued alliteration. Ord, for example, occurs just as frequently, but only once in continued alliteration. ${ }^{207}$ Eorðe has six occurrences, with only one in lines of continued alliteration (l. 233). If this is a chance coincidence of features, then it is curious that it falls on

203 ، ...that here stands an honourable noble man with his troop, who will defend this country, the land of my lord Æpelred.'

204 ، ... when the kinsman of Offa first realised that the noble man would not put up with cowardice...'

205 'As resolute the noble went to the peasant, each of them intended harm to the other...'

206 ،...now our lord, a noble man, lies on the earth; there is a need for all of us to encourage one another.'

${ }^{207}$ In lines 47, 60, 110, 124, 146, 157, 226, 253, 273; in continued alliteration 69-70, but in the sense 'vanguard'. 
the key term for the most important person at the battle. Whether or not eorl has for the poet also taken on the sense of ealdormon to indicate Byrhtnoð's specific rank, ${ }^{208}$ it certainly has a unique combination of senses perfectly fitting the presentation of Byrhtnoð: 'heroic warrior' (its poetic sense), 'a man of noble birth', and 'a person of high authority'. ${ }^{209}$ The poet confers a heroic mantle on a historical figure of elevated social status and, quite appropriately, the principal term for him is given preferential or honorific treatment. ${ }^{210} \mathrm{~A}$ similar coinciding of the repetition of thematically important lexis and continued alliteration is a feature of at least one Middle English alliterative poem. ${ }^{211}$

\section{d. Interlaced alliteration}

There is little in Old English poetry to match the self-conscious and elaborate alliterative patterns found in some Middle English poems. The Wars of Alexander has an opening which appears to have been originally composed in six quatrains with each set of lines alliterating on the same sound. ${ }^{212}$ The rhyming and alliterative De Tribus Regibus Mortuis has thirteen-line stanzas with the regular alliterative scheme aabbccddddeff. ${ }^{213}$ Stanzas are rare in Old English poetry: Seasons for Fasting (with three exceptions) and The Creed (excluding the final ten lines) both exhibit eight line stanzas, but without any alliterative patterning either within or across the stanzas. ${ }^{214}$ Stanzaic schemes and interlaced alliteration are not, however, wholly absent from Old English poetry. Raw has remarked upon two sentences of the penitential poem A Prayer (lines 11-20) 'whose words and rhythm parallel each other exactly'; she might have noted too that the alliteration of the first exactly mirrors that of the second producing two five lines stanzas with the alliterative structure $a b c d a / a b c d a:{ }^{215}$

Se byð earming pe on eorðan her Se byð eadig, se pe on eorðan her dæiges and nihtes deofle campað dæiges and nyhtes drihtne hyræð and his willan wyrcð; wa him pære mirigðe, and a hys willan wyrcð wel hym pæs geweorkes; ponne he ða handlean hafað and sceawað ðonne he ða handlean hafað and sceawað

${ }^{208}$ See on this, J. McKinnell, 'On the Date of The Battle of Maldon', MÆ 44 (1975), 121-36 and Maldon, ed. Scragg, pp. 26-7.

${ }^{209}$ DOE, eorl, senses 1b, 1a, and 5, respectively.

${ }^{210}$ Further possible evidence of honorific treatment of Byrhtnoð is provided by the appearance of triple alliteration at two moments where the hero is commanding his troops: 2a Het pa hyssa hwœene and 74a Het pa hœleða hleo; cf. above on triple alliteration and the divine word.

${ }^{211}$ Note recurrence of riding and round table in Morte Arthure (at, e.g., lines 2790-5, 2983-8, 4117-18, etc); see, on this, Morte Arthure, ed. J. Finlayson (London, 1967), p. 29.

${ }^{212}$ See The Wars of Alexander, ed. H. N. Duggan and T. Turville-Petre, EETS ss 10 (Oxford, 1989), p. xix.

${ }^{213}$ See T. Turville-Petre, “"Summer Sunday”, “De Tribus Regibus Mortuis”, and “The Awntyrs off Arthure”: Three Poems in the Thirteen-Line Stanza', RES 25 (1974), 1-14, at 6-7.

${ }^{214}$ See The Old English Poem 'Seasons for Fasting: a Critical Edition, ed. M. P. Richards (Morgantown, WV, 2014), pp. 20-2.

${ }^{215}$ B. Raw, The Art and Background of Old English Poetry (London, 1978), pp. 124-5. S. Larratt Keefer notes too that in MS Cotton Julius A. ii, fol. 136r of the poem, the 'twinned or contrasted phrases and expressions are located in exactly the same spaces on their respective manuscript lines'. See her 'Respect for the Book: A Reconsideration of 'Form', 'Content' and 'Context' in Two Vernacular Poems', New Approaches to Editing Old English Verse, ed. S. L. Keefer and K O’Brien O’Keefe (Cambridge, 1998), pp. 21-44, at 31 and 38. Note, too, that this poem contains one of the longest passages in the corpus of alternating vocalic and consonant alliteration (ll. 48-56). 
bute he pæs yfeles ær geswyce.

gyf he ealteawne ende gedreogeð. ${ }^{216}$

The 'envelope pattern' is a common rhetorical feature of the poetic style. Bartlett defines it as 'any logically unified group of verses bound together by repetition at the end of (1) words or (2) ideas or (3) words and ideas which are employed at the beginning'. ${ }^{217}$ The device is here extended to phonetic repetition: two exactly parallel alliterative envelopes are bound together by repeated vocalic alliteration in the first and last lines. The moral contrast is sharply pointed by the patterned repetition that extends from lexis, phrasing and syntax to metre, alliteration and form.

Lewis has pointed to several examples in The Phoenix of short bursts of interlaced alliteration which he regards as a 'fairly regular feature of this poem': notably, at the beginning of the poem, lines 3-6 alternate $f$ - alliteration with $m$-, and 401-5 interlace vocalic and $b$ alliteration. ${ }^{218}$ McFadyen adds lines $54-7(s-/ w-/ s-/ w-)$ which close a lengthy co-ordinate structure of parallel phrases. ${ }^{219}$ Whether these bursts serve particular rhetorical functions or are a part of the poet's general attempt to create an alliterative intensity befitting his subject is not, however, entirely clear, although Lewis feels that they serve semantic and thematic purposes. More recently, Leneghan has recently pointed to Psalm 104.5 of The Metrical Psalms as an example of interlaced alliteration in which the first and last lines of the verse alliterate on $m$ and pick up on the same alliterative sound in the Latin source in the Roman Psalter 'to produce a more aurally patterned, self-contained verse' ${ }^{220}$ Leneghan argues that such artistry and other forms of ornamental alliteration in this text are designed to increase the memorability of the verse. ${ }^{221}$ In truth, however, short bursts of interlaced alliteration occur sporadically across the corpus. Appendix Three lists those which display at least four lines of such patterning (Ps 104.5 having merely three lines); italicised there are passages where lexical repetition coincides with repeated alliteration (for the two frequently coincide, as in the passage from A Prayer). Amongst the Psalms, the final incomplete psalm 150 provides, perhaps, a better example for Leneghan's argument, although the surviving verses seem linked in a chain, rather than selfcontained:

1. Heriað on pam halgum his holdne drihten,

216 'A poor wretch is he who fights on the devil's side [day and night] and does his will here on earth; woe to him for such delight when he receives and beholds its reward, unless he quits that evil beforehand. Blessed will he be who obeys the Lord day and night and always does his will here on earth; it will be well for him in return for that effort, when he receives and beholds its reward, provided he carries the work through to a perfect end.' The translation is from Old English Shorter Poems, Volume I Religious and Didactic, ed. and trans. C. A. Jones, DOML 15 (Cambridge, MA, 2015), p. 105.

217 See A. C. Bartlett, The Larger Rhetorical Patterns in Anglo-Saxon Poetry (New York, NY, 1966), chapter II, pp. 9-29, at 9.

${ }^{218}$ R. A. Lewis, 'Old English Poetry: Alliteration and Structural Interlace', Language and Style 6 (1973), 196-205, at 200-2.

${ }^{219}$ N. L. McFadyen, 'Reading between the Lines: Patterns of Alliteration in Old English', Literary and Historical Perspectives of the Middle Ages: Proceedings of the 1981 SEMA Meeting, ed. P. W. Cummins, et al. (Morgantown, WV, 1982), pp. 148-55, at 149-50. For a full list, see Appendix Three.

${ }^{220}$ F. Leneghan, 'Making the Psalter sing: the Old English Metrical Psalms, Rhythm and Ruminatio', The Psalms and Medieval English Literature: From the Conversion to the Reformation, ed. T. Atkin and F. Leneghan (Cambridge, 2017), pp. 173-97, at 184.

${ }^{221}$ Leneghan, 2017, p.189. 

heriað hine on his mægenes mære hælu.
2. Heriað hine swylce on his heahmihtum, heriað hine æfter mode his mægenprymmes.
3. Heriað hine on heoðre holdre beman...222

The lines display an $a b / a b / a$ alliterative structure with alternation of $h$ - and $m$ - alliteration (with, too, enjambed alliteration on $h$ - in 150.1.2 to 2.1 and on $m$ - in 2.1 to 2.2) which follows the psalm's verse structure. That this is design-rather than accident-is suggested by comparison with the glosses to these verses in The Vespasian Psalter (which here is as close as any of the surviving Anglo-Saxon psalter-glosses to the lexis of the verse in The Metrical Psalms):

1. hergað dryhten in halgum his / hergað hine in trymenisse megnes his.

2. hærgað hine in maehtum his / hergað hine efter mengu micelnisse his.

3. hergað hine in swoge hornes... ${ }^{223}$

The versifier's vocabulary is very similar to that of the psalter gloss tradition (allowing for the additions necessary to create regular alliterative lines), which is also dominated by words beginning with $h$ - and $m$-. He allows the imperative heriaz to dictate the alliteration of his first, third and fifth lines (which correspond to the first clauses of the three surviving psalm verses). He chooses to ignore it, however, in the second and the fourth which are the closing clauses of the first two psalm verses, choosing instead the words beginning with $m$ - to drive the alliteration. Where five consecutive lines of alliteration on $h$ - might have resulted, instead the outcome is interlaced alliteration, with enjambed alliteration as a side effect. Passive use of the gloss tradition here would very probably have resulted in one type of ornamental alliteration or another, and as there is no example of consonant alliteration continued over five lines in the surviving poetic corpus, this pattern of interlace may mark a wish to avoid an excess of another kind of ornament. The result, nonetheless, is a striking, patterned echoing of one psalter verse by another, arising almost to a stanzaic effect. ${ }^{224}$

Systematic and repeated use of interlace, albeit not stanzaic, appears in the corpus only in the dialogues of Solomon and Saturn. Interlacing of four lines is shown by I.32-5, 63-6, II 205-8, 444-7 and of five lines by II 282-6. I. 63-6 begin Solomon's speech on the richness of

222 ' 1 . Praise the gracious Lord in his holy ones, praise him in the sublime security of his power. 2. Praise him, likewise, in his lofty powers, praise him according to the temper of his majesty. 3. Praise him in the sound of his trusty trumpet...'. The translation is from Old English Psalms, ed. and trans O’Neill, p. 607.

${ }^{223}$ See The Vespasian Psalter, ed. S. Kuhn (Ann Arbor, MI, 1965), p. 146. The Roman Psalter here reads Lavdate dominum in sanctis eius, laudate eum in firmamento uirtutis eius. Laudate eum in potentatibus eius, laudate eum secundum multitudinem magnitudinis eius. Laudate eum in sono tube. A number of the psalter glosses have byman rather than Vespasian's hornes for tube. For an overview of scholarship on the relations of the O.E. psalter-glosses, see M. J. Toswell, The Anglo-Saxon Psalter, Medieval Church Studies 10 (Turnhout, 2014), pp. 225-42. As she concludes, 'the most striking feature of the Old English glossed psalters remains the remarkable sameness of their vocabulary' (at p. 242).

${ }^{224}$ A longer, but apparently simpler, example of alliterative interlace where repetition in the Latin is echoed by repetition in the versification and results in psalm verses with almost identical patterns of alliteration occurs at PPs 117.1.1-4.4 (for thirteen lines, excepting 4.2, the pattern vowel-/g-/m- recurs). On psalm stanzas and refrains, see P. R. Raabe, Psalm Structures: A Study of Psalms with Refrains (Sheffield, 1990). 
divine speech, II. 444-7 are the start of Saturn's rhetorical question on the power of Fate, and II 282-6 open Saturn's riddle on Age; I. 32-5 closes Solomon's speech on the unhappy lot of the man who cannot sing in praise of Christ. Only II 205-8 neither opens nor closes a speech. In the rest of the corpus there are only six instances of this feature. ${ }^{225}$ II. $282-6$ provides the best evidence in this group of artifice:

Ac hwæt is ðæt wundor ðe geond ðas woruld færeð, styrnenga gæð, staðolas beateð, aweceð wopdropan, winneð oft hider?

285 Ne mæg hit steorra ne stan ne se steapa gimm, wæter ne wildeor wihte beswican... ${ }^{226}$

Menner shows that the opening phrasing of the riddle question in line 282a is traditional. ${ }^{227}$ If interlaced alliteration was planned from this beginning, then the alliteration of lines 284 and 286 was generated by this formula (just as that of line 282b is). ${ }^{228}$ The intervening alliterations on st- are unusual in that one or other of the alliterations in the attested clusters of four or five interlaced lines in the corpus is very frequently vocalic (and the ease of such alliteration is perhaps a pointer to accidental patterning in some short clusters); here, however, there is alliteration on one of the rarest word-initial sounds - which makes the pattern aurally clearer, although it must have been harder to achieve. ${ }^{229}$ That both the dialogues share this rare stylistic feature provides support for Anlezark's opinion that 'a number of shared idiosyncrasies show that if they are not one author's work, the circle which produced them was a close one'. ${ }^{230}$

Two passages in the corpus show poets using interlace more extensively, producing verse which is radically different from the norm. We may take first the prose source and the verse of Metre 20.117-32 of The Metres of Boethius:

${ }^{225}$ Sat 275-8, El 288-91, Jul 247-50, Rid 19.1-4, PPs 76.8.1-4, and GuthA 296-300.

226 'But what is the wonder that travels through the world, goes inexorably, beats the foundations, awakens tears, often struggles its way here? No star, nor stone, nor the bright gem, no water, nor the wild beast can deceive it at all...'. The translation is from Old English Shorter Poems Volume II Wisdom and Lyric, ed. and trans. R. E. Bjork, DOML 32 (Cambridge, MA, 2014), p. 155.

227 "The formula introducing the riddle of Old Age “Ac hwæt is ðæt wundor” is the characteristic formula of many of Odin's riddles in his contest with King Heiðrek: "Hvat er pat undra”.' See The Poetical Dialogues of Solomon and Saturn, ed. R. J. Menner (New York, NY, 1941), p. 65, and n. 19.

${ }^{228}$ The riddles of Odin with this opening formula Hvat er pat undra ('What strange marvel...') are always followed by the further set phrases er ek úti sá, fyrir Dellings durum ('...did I see without, in front of Delling's door'); see, for the relevant riddles, The Saga of King Heidrek the Wise, ed. C. Tolkien (London, 1960), pp. 34-5, 43, 80-1. It is possible, accordingly, that the Old English version of the formula came with an expectation of some sort of following fixed form.

${ }^{229}$ Particularly so if the poet was also following a Latin source: see T. D. Hill, 'Saturn's Time Riddle: An Insular Latin Analogue for Solomon and Saturn lines 282-291', RES 39 (1988), 273-6, and Solomon and Saturn, ed. Anlezark, pp. 20-2. Hill observes rightly, however, that 'this medieval Latin analogue does not necessarily make the Old English riddle any less Germanic than Menner supposed' (p. 275).

${ }^{230}$ Solomon and Saturn, ed. Anlezark, p. 49. 


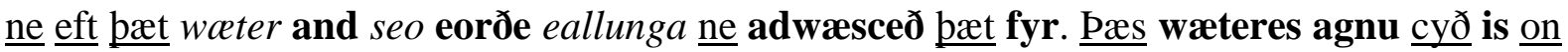
eorpan, and eac on lyfte, and eft bufan bam rodore. Ac bæs fyres agen stede is ofer eallum woruldgesceaftum gesewenlicum, and peah hit is gemenged wið ealle gesceafta; and peah ne mæg nane bara gesceafta eallunga ofercuman, forbam be hit næfð leafe pæs almihtigan. ${ }^{231}$

Ne pincð me pæt wundur wuhte be læsse

pæt ðios eorðe mæg and egorstream

(swa ceald gesceaft) cræfta nane

120 ealles adwæscan pæt pæt him on innan sticað

fyres gefeged mid frean cræfte.

pæt is agen cræft eagorstream[e]s,

wætres and eorpan, and on wolcnum eac,

and efne swa same uppe ofer rodere.

125 Donne is pæs fyres frumstol on riht,

eard ofer eallum oðrum gesceaftum

gesewenlicum geond pisne sidan grund;

peah hit wið ealla sie eft gemenged

weoruldgesceafta, beah waldan ne mot

130 pæt hit cenige eallunga fordo

butan pæs leafe pe us bis lif tiode,

pæt is se eca and se ælmihtiga. ${ }^{232}$

Words in bold are shared between the two passages. Words underlined in the prose are those omitted from the verse rendition; those so underlined in the verse are additions to the prose. Italicised words in the verse are those that replicate an idea in the prose but vary its lexis (e.g. wceter in the first line of the prose has been transformed into the poetic compound egorstream). For all sixteen lines of the verse, the versifier maintains a regular alternation of consonant and vowel alliteration forming the most extensive passage of this type of patterning in the surviving corpus by some distance. This orderly alternation is, also-evidently-an achieved effect, for the verse, although it follows the ideas of the prose, does not adhere especially closely to its lexis for most of this section. ${ }^{233}$ Lines $117-21$ and $131-2$ are almost wholly independent of the

${ }^{231}$ The text is from Old English Boethius, ed. Godden and Irvine, vol. I, p. 316. ' ...nor again the water and the earth do not wholly extinguish the fire. Water's own territory is on the earth and also in the air and also above the firmament. But the fire's own place is above all visible creatures of the world, and yet it is mixed with all elements because it does not have the Almighty's leave; the translation is from Old English Boethius, ed. Godden and Irvine, vol. II, p. 52.

232 'It does not seem to me any less a miracle that this earth and sea — such cold creatures — can in no way entirely extinguish what of fire adheres within them, joined by the lord's skill. It is the special homeland of the sea, of water [to be] on earth and also in the clouds and likewise above the heavens. The original place, the homeland of fire is properly above all creatures visible across this spacious earth. Though it is mixed again with all earthly creatures, yet it may not manage to destroy anything entirely except by the leave of the one who granted us this life: that is the eternal and almighty one.' The translation is from Old English Boethius, ed. Godden and Irvine, vol. II, pp. 150-1.

233 The relevant part of the Latin reads: 'Tu numeris elementa ligas ut frigora flammis/ Arida conveniant liquidis, ne purior ignis/ Evolet aut mersas deducant pondera terras', 'You bind its elements with law, so that the cold come together with flames, the dry with liquids, lest the fire too pure fly off, or lest its weight pull down the overwhelmed earth' (see Boethius: The 
vocabulary of the prose. The intervening lines much more closely depend on the phrasing of the prose. But changes of order and of position-Dces wæeteres agnu cyð in the prose becomes agen crceft...wæetres in lines 122-3, and the first element of woruldgesceaftum is delayed from its natural place (if the prose been followed passively) — show that the alliterative interlace is the product of particular and deliberate changes to the prose. ${ }^{234}$ Vowel alliteration is commoner in The Metres Of Boethius than in any other poetic text with nearly one in three lines exhibiting it, ${ }^{235}$ so that such alternation was easier to achieve than it would have been for other poets, but the resulting passage is, nevertheless, highly unusual in the Old English corpus. Audiences or readers must surely have felt that this was in some ways a different kind of poetry. The subject matter of this section - the nature of the material universe, or the relationship of the four elements of earth, air, water and fire-belongs to physics, geology, or theology, and is far removed from the heroic, biblical, hagiographic, elegiac or gnomic themes of most of the poetry. Its source in Boethius, Book III, metre 9, is, famously, a rendition of part of Plato's Timaeus (incorporating also Neo-plationist commentary from Proclus and other source material). ${ }^{236}$ This new style here was perhaps selected as appropriate for the new unusual subject, being a more elaborate, almost mannered, style for a complex philosophical idea. Each of the elements has its proper place in the divine structure and, yet, is also mixed with the others; each alliterative line has its integrity but is also chained to the others in this interlaced section. The structured alliteration can be read as a stylistic replication of the philosophical idea, the intermingling in nature echoed by an interlacing in poetry. Szarmach is right, in my opinion, to argue that the versifier in this Metre shows 'signs of vitality and even good health in an engagement with speculative thought', although 'virtuosity' may be more accurate than 'vitality'. ${ }^{237}$

No consideration of interlaced alliteration in Old English poetry can ignore Riddle 40, lines 82-91a:

Ic eorban eom æghwær brædre

ond widgelra ponne pes wong grena;

ic uttor eape eal ymbwinde,

85

wrætlice gewefen wundorcræfte.

Nis under me ænig oper

wiht waldendre on worldlife;

ic eom ufor ealra gesceafta,

para be worhte waldend user,

90

se mec ana mæg ecan meahtum,

Theological Tractates, The Consolation of Philosophy, ed. and trans. H. F. Stewart, et al. (Cambridge, MA, 1978), pp. 272-3). The Latin has not influenced the Old English verse at this point.

${ }^{234}$ For an overview and analysis of the changes made in the process of versification, see $\mathrm{M}$. Griffith, 'The Composition of the Metres: From Prose to Verse', in Old English Boethius, ed. Godden and Irvine, vol. I, pp. 80-105.

235 The longest runs of continued vowel alliteration all occur in this text (at Metre 7.42-5, 11.410, 13.70-3, 13.76.80, 16.16-20, 20.141-5, 25.56-60).

${ }^{236}$ For Boethius's sources, see J. Gruber, Kommentar zu Boethius 'De Consolatione Philosophiae', Texte und Kommentar 9 (Berlin, 1978).

${ }^{237}$ See P. E. Szarmach, 'The Timaeus in Old English', Lexis and Texts in Early English: Studies presented to Jane Roberts, ed. C. J. Kay and L. M. Sylvester, Costerus New Series 133 (Amsterdam, 2001), pp. 255-67, at 255. 


$$
\text { gepeon prymme... }{ }^{238}
$$

The riddle is a versification of the last of Aldhelm's Enigmata, no. 100 Creatura. ${ }^{239}$ But these lines are far from a slavish translation of the source. Lines 84-90 of the Riddle render lines 5960 and 62-4 of the Latin; but lines 82-3 are a verbatim repeat of lines 50-1 of the Old English (rather than a direct version of lines 61-2 of the Latin to which they are parallel in the versification):

$$
\begin{aligned}
& \text { Ic eorpan eom } \begin{array}{l}
\text { æghwær brædre, } \\
\text { ond widgielra }
\end{array} \text { ponne pes wong grena. } \\
& \text { 240 }
\end{aligned}
$$

These lines render line 27 of the source: Latior, en, patulis terrarium finibus exto. ${ }^{241}$ Line 50 shows vocalic alliteration and 51 alliteration on $w$-; and, remarkably, this pattern is maintained for nine consecutive lines throughout lines 82-90-the longest such passage in the corpus by far. There are also traces of other alliterative devices: notably, enjambed alliteration in lines 84-5 (of $w$-) and 89-90 (of vowels) and a very rare feature in line 86, double alliteration in the b-verse. The subject matter is not dissimilar to that of Metre 20: the nature of the divine creation. Just as the ideas of Metre 20 are structured in terms of binaries, the four elements being both separate and yet together, so too are those of these lines, with Creation speaking of itself in terms of comparison (brcedre ond widgelra, 'broader...wider') and stratification (under...ufor, 'below...above'). Patterned verse mimics the structure of ideas, for it too is wrætlice gewefen, 'curiously woven'. Given the Anglo-Saxon interest in interlace in art and poetry, ${ }^{242}$ it is perhaps surprising that such extended supra-linear arrangements of alliteration are so very rare, but these two passages, at least-Metre 20 and Riddle 40- display its use. Both, despite belonging to different genres (metrum, riddle), are also hymns of praise to the Creator for creation. A powerful motivation for the use of special alliterative effects in bothas with Cædmon's Hymn and the opening to Genesis A, and Psalm 150 too-is the wish the better to praise the Almighty. As all of these texts are versions of high status source texts with distinguished authors, we may, perhaps, also detect in these passages the power of literary authority, and a stretching of the limits of the traditional style fittingly to clothe such grand material.

\section{e. Enjambed alliteration}

238 'I am everywhere broader than the earth and wider than this green wold. I easily embrace everything at a distance, curiously woven with wondrous power. There is no other creature below me in this mighty earthly life; I am above all things whom our Ruler created, who alone can mightily tame me with eternal power...'. The translation is from R. K. Gordon, AngloSaxon Poetry (London, 1934), p. 334.

${ }^{239}$ For the Latin, see Aldhelmi Opera, ed. R. Ehwald, MGH Auct. Antiq. 15 (Munich 1984), pp. 145-9.

240 'I am everywhere broader than the earth, and wider than this green plain.'

${ }^{241}$ J. H. Pitman, The Riddles of Aldhelm, YSE 67 (New Haven, CT, 1970), p. 63 renders line 27 as: 'Lo, wider than the far-flung ends of earth' and (on p. 65) lines 61-2 'Senis, ecce, plagis, latus qua panditur orbis,/ Ulterior multo tendor, mirabile fatu' as 'Much further, wonderful to tell. I reach/ Than those six zones that mark the world's extent'.

242 See J. Leyerle, 'The Interlace Structure of Beowulf', Interpretations of 'Beowulf': A Critical Anthology, ed. R. D. Fulk (Bloomington, IN, 1991), pp. 146-67, with general overview at 14651. 
Enjambment of alliteration across lines does not involve the fourth stress of the line in the alliteration of its own line - to which we should expect audiences to have been sensitive- - but, rather, in that of the following line. This feature is common in the corpus: over 1700 lines display it (or approximately 1 in 17 lines in the corpus), and opinions have varied as to its significance. ${ }^{243}$ Bredehoft calculates that in the first thousand lines of Beowulf 'we ought to expect about 73 or 74 cases of such linking alliteration, and by my count there are 72 examples' and cautiously concludes that 'at least in this stretch of the poem, the frequency of such linking alliteration seems consistent with the hypothesis that it is a random occurrence' ${ }^{244}$ Le Page counts two hundred and twenty instances across the poem as a whole, so that the rest of the poem does not vary in its use of this feature. ${ }^{245}$ Lehmann, on the other hand, thinks it (and continued alliteration) 'may not be accidental', but 'never succeeded in becoming a feature of Germanic poetry', although he does not make clear how that success would have manifested itself. ${ }^{246}$ Oakden takes its occurrence in successive lines as evidence that it is a conventional device, ${ }^{247}$ and points to its appearance in 'all the alliterative romances' of the Middle English period as 'proof of the continuity of the tradition'. ${ }^{248}$ Borroff appears to agree. ${ }^{249}$ Lewis argues that, for the Beowulf-poet, it functions in a great many instances 'as a kind of punctuation', where 'the b-verse begins a major syntactic unit... or the a-verse ends one'. ${ }^{250} \mathrm{He}$ lists thirty examples. But there are rather more occasions in the poem where the b-verse containing the 'anticipatory' alliteration closes a clause or sentence, twice at the ends of fits. ${ }^{251}$ Many of these show clause-final displaced finite verbs, especially forms of wesan and weorðan and the modal auxiliaries (lines 227b-9):

$\begin{array}{ll}\text { pæs pe him yplade } & \text { Gode pancedon } \\ \text { eaðe wurdon. } & \\ \text { Pa of wealle geseah } & \text { weard Scyldinga... }\end{array}$

A new sentence with a new subject begins in line 229, but the alliteration is continued from wurdon to wealle. If the former 'anticipates' the latter, it is difficult to see how it does this in any way other than the phonetic. In cases such as this, Bredehoft's view that the alliteration is the product of chance seems correct. But, where there is enjambment of sense as well as of alliteration, Lewis is right to suspect that something more interesting may be going on. Taking,

\footnotetext{
${ }^{243}$ See Appendix Four for a complete list.

${ }^{244}$ Bredehoft, 'Estimating Probabilities', p. 20.

${ }^{245}$ See Le Page, 'Alliterative Patterns', pp. 439-40 for a complete list. Le Page concludes, however, that the poet avoided this and all alliterative features crossing lines (at p. 438).

${ }^{246}$ W. P. Lehmann, The Development of Germanic Verse Form (Austin, 1956), p. 48.

247 Oakden does not note that the poetic part of the genealogy of Æpelwulf, quoted above, displays regular enjambed alliteration as a necessary consequence of its formal linking across lines of name and patronymic derived from the name. Continued enjambed alliteration may, therefore, have begun in Germanic genealogical poetry.

${ }^{248}$ Oakden, Alliterative Poetry, pp. 148-9 and 154, respectively.

${ }^{249}$ M. Borroff, Metrical Study, p. 233, n. 23: 'It is possible also for the final important word to show "anticipatory alliteration" with the line that follows'.

${ }^{250}$ Lewis, 'Plurilinear Alliteration', pp. 593 and 595.

${ }^{251}$ At ll. 169, 248, 233, 332, 472, 538, 674, 757, 777, 861, 924 (end of fit XII), 957, 1012, 1055, 1315, 1407, 1411, 1454, 1508, 1572, 1617, 1631, 1803, 1869, 1908, 2113, 2144, 2220 (end of fit XXXI), 2315, 2396, 2568, 2588, 2635, 2640, 2650, 2704, 2719, 2983, 3050, 3065. 252 'They thanked God that the sea-voyage had been peaceful for them. Then from the rampart the watchman of the Scyldings saw...'
} 
in the first instance, as Bredehoft does, only examples from the first thousand lines of Beowulf, stylistic motivation seems to generate a number of instances. Compare for example:

$$
\text { on bearm nacan } \begin{gathered}
\text { Secgas bæron } \\
\text { beorhte frætwe }
\end{gathered}
$$

and

$$
\begin{array}{ll} 
& \text { sæbat gehleod, } \\
\text { bær on bearm scipes } & \text { beorhte frætwa [1l. 895b-6] }
\end{array}
$$

There is near lexical and semantic identity between lines 213b-14 and 896 . Two poetic idioms overlap in both: first, the idea of bearing something bright, with collocation of beran and beorht, ${ }^{253}$ and second, that of loading valuable freight into the hold of a boat, with metaphorical use of bearm 'bosom', in a formulaic prepositional phrase. ${ }^{254}$ In the second quotation, the verse-initial finite bcr participates in double alliteration with bearm. In Bliss's view, this alliteration is functional. ${ }^{255}$ But, if we are to believe Bredehoft, the same verb in the first quotation, now verse-final in the line preceding the same noun, but still alliterating with it, and in collocation with the same adjective, does so merely by chance in a fashion devoid of literary significance. But the enjambed alliteration surely draws attention to these traditionally linked ideas and sets up an echo between the two scenes that is only heard later. Beowulf, with a boat full of men and weapons, sets off on his quest to kill a monster and win glory; Sigemund, with a boat full of treasure, starts for home having achieved greatest glory as a dragon-slayer. The beginning and the end of the heroic cycle are coupled. Enjambment of syntax allows traditional phrasing to be broken across two lines, and if that phrasing displays double alliteration, then enjambment of alliteration results.

The idea that formulaic language might sometimes have been re-arranged by the poets across lines is not new. Nicholson has shown how enjambed hypermetric verses may display combinations of traditional phrasings as 'the singer splits and amalgamates formulas to form complicated, brilliant patterns' ${ }^{256}$ Only the best poets, he believes, were capable of using their materials so densely and economically. Nicholson does not, however, consider the role of enjambed alliteration in such patterns and none of his examples shows it. But it is nonetheless a demonstrable technique, used by the Beowulf-poet and others. Some, perhaps, are obvious enough collocations:

Sele hlifade

$$
\text { heah ond horngeap [1l. 81b-2] }
$$

${ }^{253}$ See also Ex 219a beran beorht searo, Beo 231 beran...beorhte randas, GuthA 798 berað...beorhtne geleafan.

${ }^{254}$ See also Ex 375 on bearm scipes beornas feredon and Beo 34-5 aledon...on bearm scipes. 255 The verse scanning as Type 1A2a, with the verb stressed by virtue of belonging to his Group (2): undisplaced, but 'in apposition to a verb in group (1) which immediately precedes it' (Bliss, Metre, p. 10).

${ }^{256}$ L. E. Nicholson, 'Oral Techniques in the Composition of Expanded Anglo-Saxon Verses', PMLA 78 (1963), 287-92, at 290. 
As it is not possible for a hall to 'tower' in any other way than 'high', the adjective is tautologous, but the tautology is used less interestingly elsewhere to achieve a whole-verse formula with double alliteration. ${ }^{257}$ Or, again, in lines 88-90a, when Grendel is provoked

\section{...pæt he dogora gehwam dream gehyrde \\ hludne in healle; bær wæs hearpan sweg, swutol sang scopes. ${ }^{258}$}

Revelry in the hall must surely have been noisy, and the formulaic combination of the verb gehyran and adjective hlud occurs elsewhere in a number of instances. ${ }^{259}$ Here, however, the continued enjambed alliteration (together with cluster alliteration in sweg/swutol, and crossed alliteration in line 88) supplements the sense mimetically. The noisy sound effects suggest merry-making. That Grendel, however, hears the Danish partying resound not just every day, but loudly too, with noise of harp and singing of poet—and, perhaps, a little too much mead as well?-provides explanation of a sort for his rage. Who, exactly, we may wonder, are the neighbours from hell? And although it is the Creator and his creation that the Danes, oblivious to the threat of Grendel, appear to be celebrating so rowdily, we may wonder too whether the scene does not touch on the poetic motif of excessive jubilation before a comeuppance or downfall. ${ }^{260}$ Excess alliteration plays an important role in these connotations. ${ }^{261}$

Other examples in this thousand lines - enhancing varying rhetorical effects - are easy enough to find, ${ }^{262}$ but other poets too take the opportunity offered by hakenstil to play with

${ }^{257}$ Heah hlifi(g)an at Dan 602a, Beo 2805a, hea(h) hlifiað at Phoen 23a, 32a. The Andreaspoet uses (and, perhaps, has borrowed from Beowulf) heah ond horngeap at 668a, but without enjambment of alliteration.

258 ، ... when, every day, he heard loud rejoicing in the hall; there was the sound of the harp, the minstrel's clear song.'

${ }^{259}$ Hlud gehyred (or gehered) at Sat 606a, ChristB 492a, 834a, ChristC 948a, although in all cases associated with heavenly rather than earthly noise. Stanley, Foreground, p. 136 notes the alliterative facts, but does not allow onomatopoeia.

${ }^{260}$ Compare the noisiness of Holofernes' partying in Judith (with attendant alliterative and rhyming effects) before his decapitation the same night (Jud ll. 23-5) and the laughter of Byrhtnoð in Maldon just before he is cut down in battle (Mald ll. 146-7), which Robinson suggests may be 'a conventional dramatic signal that a mortal blow is imminent at the moment when the threatened person least expects it' (F. C. Robinson, 'God, death, and loyalty in The Battle of Maldon' The Tomb of 'Beowulf' and Other Essays on Old English, ed. F. C. Robinson (Oxford, 1993), pp. 105-21, at 113, n. 33). The motif is found too in Beowulf: as Tucker has argued, the joy of Grendel in ll. 730-4 precedes and perhaps signals his own imminent demise (S. I. Tucker, 'Laughter in Old English Literature', Neophil 43 (1959), 222-6).

261 A. Orchard, A Critical Companion to Beowulf (Cambridge, 2003), pp. 62-3 notes the range of alliterative effects in this passage, but concludes only that these 'highlight' the passage.

${ }^{262}$ Note, for example, with semantic association: 217-18 gefysed/flota (cf. El 226a, And 1698), 334-5 -helmas/here- (cf. And 10, Finn 45), 476-7 -werod/wig- (cf. Ex 221, 233a, El 19, 48, Mald 102); with tautology: 283-4 earfoðprage/ preanyd (and cluster alliteration); with collocation: 497-8 dream/duguð, 930-1 wyrcan/wunder (cf. PPs 70. 18.2-3); with parallelism: 178-9 hyra/ hrepenra, 185-6 wenan/ gewendan; with zeugma: 92-3, 515-16, 911-12; with sententia: $287-9$ (with the enjambed alliteration continued, and also with crossed alliteration); with play on sounds: 942-3 (meg, mregba, magan); possibly supporting apo koinou at 740-1 (see H. D. Meritt, The Construction 'apo koinou' in the Germanic Languages (New York, NY, 1967), p. 16), but, given repeated enjambed alliteration at 744-5, along with cluster alliteration 
alliteration across lines, ${ }^{263}$ sometimes participating in effects very different from those seen in Beowulf. In one instance, enjambed alliteration appears to be metrically and alliteratively functional, ${ }^{264}$ but in an original and playful fashion:

\section{Ic on sipe seah SRO \\ $\mathrm{H}$ hygewloncne, heafodbeorhtne \\ swiftne ofer sælwong swipe prægan. ${ }^{265}$}

Riddle 19 contains four series of runes (that transliterate as SROH, NOM, AGEW, COFOAH) which spell out in reverse order the Old English words for 'horse' 'man' 'warrior' 'hawk', and the first letters of the reversed order spell out the solution snac, 'a swift-sailing vessel'. ${ }^{266}$ $\mathrm{SROH}$ and COFOAH are, in the usual edited text of the poem, split across lines of verse: so that, at the start, the $h$-rune hregl completes the word HORS in reverse order but forms the first alliterating stress of the second a-verse (as shown above). But the first b-verse is now short of one metrical position, for sigel, rad and os together provide only three of the required four positions. On the other hand, if HORS is read as unbroken and constitutes the entire b-verse of the first line (as a normal reader would surely interpret it initially), then the second a-verse becomes defective, being short of one metrical position. Only if we read the letter as overlapping the two verses and contributing a stress to each is the metre and alliteration of both verses satisfactory. This riddler poet undoubtedly 'took liberties with metre and alliteration', 267 for nowhere else in the corpus is there metrical overlap between consecutive verses such as is found here, ${ }^{268}$ but his runic verses are not defective and may, nonetheless, be scanned by Sieversian principles. ${ }^{269}$

in 741, triple alliteration in 743a, and rhyming verbs in 741-2, perhaps one of a number of sound effects accompanying the violent dismemberment of Hondscioh. Bjork sees the use of enjambed alliteration in Beowulf's response to Unferth (at lines 533-4, 536-8, 568-9, 570-1, 585-6) as evidence of its 'stylistic bravura': R. E. Bjork, 'Speech as Gift in Beowulf', Speculum 69 (1994), 993-22, at 1012; certainly the use across three lines in 536-8 is relatively unusual.

${ }^{263}$ Compare, for example, Sea 65b-6a lif/ lcene on londe and alliteration of lif and lcene elsewhere in the poetry (for Sea 20-1 hleopor...hleahtor, see above on cluster alliteration), JDay II 213b-14a breost/mid bitere care and Sea 4a bitre breostceare, JDay II 240b-41a slcep/ sleac mid sluman and GuthA 343a slæpa sluman, ChristC 1204b-5a on...drege/ domes and MSol II.337a on domes dcege, etc. Occasionally, text internal echoes are created, e.g. And 7223 herigað/ halgum hleoðrum and 819 herede hleoðorcwidum haliges lare. Occasionally, the names of brothers (e.g. Beo 1323-4) or of father and son (e.g. PPs 104.15.3-4) are linked in this way. Occasionally, the link is strengthened by adnominatio (e.g. Ex 5-6, DEdw 8-9).

${ }^{264}$ In combination, too, with interlaced alliteration in lines 1-4 (on $s^{-}, h-, s^{-}, h-$ ) and cluster alliteration in line 3.

265 'On a journey, I saw ESROH, proud, bright-headed, swift, run powerfully across the plain.'

${ }^{266}$ See M. Griffith, 'Riddle 19 of the Exeter Book: SNAC, an Old English Acronym', N\&Q 39 (1992), 15-16. Horse, man and hawk re-appear in runes in Riddle 64 'Ship'; for discussion see Riddles, ed. Williamson, pp. 325-6.

${ }^{267}$ Exeter Anthology, ed. Muir, vol. II, p. 587.

${ }^{268}$ Although Sievers' view of the structure of the hypermetric verse as the running together of two normal verses provides a point of comparison.

${ }^{269}$ Assuming that the runic letters stand for the names of the runes, and further assuming that the runic consonants are stressed (as indeed must be the case with $1 \mathrm{~b} \mathrm{~S}, 1 \mathrm{~b} / 2 \mathrm{a} \mathrm{H}, 5 \mathrm{a}, \mathrm{N}, 6 \mathrm{a}$, and 8a F), but the runic vowels are not (as the failure of 1.6 to alliterate on vowels with initial 
The start of Andreas illustrates rhetorical use. After an opening sentence in which the poet announces that we have heard of twelve unnamed heroes, he goes on first to characterise their heroism before then focussing on, and naming, one of them, Matthew. The two short sections show two clear verbal echoes (lines 3b-18):

No hira prym aleg

camprædenne, ponne cumbol hneotan, syððan hie gedældon swa him dryhten sylf, heofona heahcyning, hlyt getchte.

pæt wæron mære men ofer eorðan frome folctogan ond fyrdhwate, rofe rincas, ponne rond ond hand on herefelda helm ealgodon... ...wæs hira Matheus sum se mid Iudeum ongan godspell ærest wordum writan wundorcræfte. Dam halig god hlyt geteode ut on pæt igland pær ænig pa git ellpeodigra eðles ne mihte blædes brucan; oft him bonena hand on herefelda hearde gesceode. ${ }^{270}$

At first sight this seems a kind of nonsense poetry: never did the power of the twelve fail in combat, and to this they were destined, yet one of them, Matthew, was frequently and cruelly harmed in combat, and to this he too was destined. The style quite deliberately accentuates the contradiction. There is lexical repetition of key ideas in lines which alliterate on the same sounds. The divine destiny of the group, (1. 6 heofena heahcyning hlyt getcehte) chimes at the parallel point with the contrary destiny of the member of this group, also ordained by God (l. 14 halig god hlyt geteode). The hands of the victorious twelve on the battlefield (9b-10a hand on herefelda) are matched verbatim, again at the parallel point, by the hands of the slayers who defeat Matthew in the same place (17b-18a hand on herefelda), in both cases with identical enjambment of alliteration. ${ }^{271}$ Of course, this contradiction is apparent only. The twelve heroes are the twelve apostles and their victories are spiritual. The cruel injuries done to Matthew are literal only and we come to understand too that the 'battle' in which he is harmed is comically one-sided, with the entirety of Mermedonian manhood arrayed against him. This carefully composed combination, in a parallel pattern, ${ }^{272}$ of the symbolic and the literal shows extra

$a c$ surely suggests), then the following scansions of the verses with runic letters are apparent:1b, 2E2a or 3E2, 2a 1D2, 5a 1D4 (taking the common spelling monn for mon), 6a 2B1a or 3B1a, 7b 2A1a, 8a 2E1a or 3E1.

270 'Never did their power fail in combat engagement when standards clashed, once they had dispersed, as the Lord Himself, High-King of Heaven, showed them by lot. These were renowned men on earth, brave captains, when shield and arm on the field of plunder kept helmet safe on the plain of doom. One of them was Matthew, who was the first among Jews to begin to write the Gospel in words with wondrous skill. For him did Holy God fashion the lot out to that land by water where no man from the homeland of foreigners could yet enjoy happiness: him often hands of slayers on the field of plunder cruelly harmed.' The translation is from Andreas: An Edition, ed. R. North and M. D. J. Bintley (Liverpool, 2016), p. 118. On 18b gesceode 'fell upon', see Andreas, ed. Brooks, p. 62; the contradiction remains whether the form is from gesceon 'fall on', or gesceððan, 'harm'.

${ }^{271}$ Orchard notes that hlyt is found only at these two points in the poem and that the repetition ' $h l y t . . . h a n d$ on here-felda is the poet's own, unattested elsewhere in the extant corpus', see his 'The Originality of Andreas', Old English Philology, ed. Neidorf, et al., pp. 331-52, at 335.

${ }^{272}$ On the parallel pattern, see Bartlett, Rhetorical Patterns, chapter III. Precise use of such a pattern, as here in Andreas, shows the device moving towards a structure akin to stanza and refrain. 
alliteration used, along with other devices, for a structural end: an orderly absorption of the heroic into the hagiographic. ${ }^{273}$

As with other forms of additional alliteration, clusters of this type of supererogation sometimes occur. Terasawa cites Elene 65b-75a, which contain two runs of three lines (1l. 668 and 70-72, with another instance in 74). Beyond calling this 'intricate', he does not explain further, perhaps implying that he believes that it is an excess for the sake of it, or a kind of exhibitionism. ${ }^{274}$ The longest display of such enjambment is found in Metre 29 of The Metres of Boethius. The relevant parts of the prose and verse are as follows (with bold, italics and underlining used as before):

hwilum he gemengeð bæt fyr wið bam cile; hwilum æt leohte fyr $\underline{7}$ bæt beorhte up gewit, $\underline{7}$ sio hefige eorðe sit pær niðere. ${ }^{275}$

hwylum he gemengeð, metodes cræfte,

cile wið hæto; hwilum cerreð eft

50

on uprodor æalbeorhta leg,

leoht on lyfte; ligeð him behindan

hefig hrusan dcel, beah hit hwile ær

eorðe sio cealde oninnan hire

heold and hydde haliges meahtum. ${ }^{276}$

[29.48-54]

Godden comments on lines 52-4, which are additional to the prose, that 'independently of the prose, the verse seems to be recalling the point made in Metre 20 about fire being retained within the earth (CM 20.118-21; compare B 33.188-91)' ${ }^{277}$ Of course, as we have seen, it was in that earlier passage that we found one of the most remarkable and extended passages of interlaced alliteration in Old English poetry. Here in this section which looks back directly to it in subject matter, we find the most extended example in the corpus of enjambed alliterationsix consecutive lines of it-in a passage also strongly marked by enjambment of sense (which is surprising in a text characterised much more than is usual by end-stopping). ${ }^{278}$ Godden's point can be strengthened: the versifier, encountering the same theme as in this section of Metre 20 , adds and reacts to it with similar rhetorical fervour, and in doing this, he made the task of versifying the prose considerably more difficult for himself, needing either three alliterations on the same sound rather than two, or four rather than three in those lines where there is double

${ }^{273}$ On 'the poet's attempt to develop a hagiographical representation of Andrew as imago Christi and miles Christi', see I. Herbison, 'Generic Adaptation in Andreas', Essays on AngloSaxon and Related Themes in Memory of Lynne Grundy, ed. J. Roberts and J. Nelson (London, 2000), pp. 181-211, at 211.

274 See J. Terasawa, Old English Metre: An Introduction (Toronto, 2011), p. 19.

275 'Sometimes he mixes the fire with the cold. Sometimes the light and bright fire goes up and 'the heavy earth sits down below.' The translation is from Old English Boethius, ed. Godden and Irvine, vol. II, p. 87.

276 ، ... at times he mingles the cold with heat by the skill of the creator; at times a very bright flame turns back into the sky above, light into the air; behind it remains the heavy part of the earth, though the cold earth previously held and hid it within itself by the power of the holy one.' The translation is from Old English Boethius, ed. Godden and Irvine, vol. II, p. 190.

277 Old English Boethius, ed. Godden and Irvine, vol. II, p. 519.

${ }^{278}$ See Griffith, 'The Composition of the Metres: Prosody', Old English Boethius, ed. Godden and Irvine, vol. I, pp. 105-34, at 133: around 65\% of sentences in the Metres are end-stopped, being more than three times the rate found in Guthlac B and Judith. 
alliteration in the a-verse. ${ }^{279}$ Some of these sounds are not common ones in the alliterative system ( $c$-: $2.5 \%$ of lines in the corpus, $l-5.2 \%$ ), and this added to the difficulty. Nothing in the language or style of the prose at this point led the versifier to this pattern; it is wholly and clearly of his devising. Leg, for example, in line 50 replaces fyr, and behindan substitutes in line 51 for niðere, though both these words from the prose would have filled the fourth positions of their respective lines as sensibly and have scanned just as well. Where fyr occurs in the prose metra it is always, with only the exception of this passage, ${ }^{280}$ retained in the versification; only here in the whole text does leg substitute for it. ${ }^{281}$ The sole reason for these changes is to achieve the enjambed alliteration. Metodes crcefte, 'by the skill of the creator', in line 48b is, accordingly, not, as Krapp thinks, an addition which is 'merely metrical padding', for it begins the enjambed section, and the allusion to divine 'craft' stimulated the poet's rhetorical move, divine artistry encouraging human. ${ }^{282}$ The section finishes in 54b with haliges meahtum,'by the power of the holy one', a repeat of the idea (and grammar) of 48b which closes this particularly polished example of an envelope pattern. Overall, the effect, then, is imitative: the interlocking of binaries in nature is mirrored by this interlocking of lines in verse, and the hiding of the fire within the earth, of the heat inside the cold, is mimicked by the ring structure. There is a perfect match of form and content. ${ }^{283}$ Though some traditional devices are evident, nonetheless, we can see that here again in The Metres of Boethius they are being stretched towards a new mimesis, that is, not a simple mimesis that is imitative of sound, but rather an attempt to replicate the structure of an idea. ${ }^{284}$

\section{2: Licentious alliteration}

The alliteration of a line should not extend to its final stress. This rule is demonstrated by the empirical evidence of almost every line of the corpus. The absence is generated by the structure of the line. For those who believe that a tree diagram best describes this structure, with the first verse strong and the second verse weak, and, beneath that level, the first stress in each verse strong and the second weak, then, as Russom states, 'a weak constituent of a weak constituent may not contain an alliterating syllable'. ${ }^{285}$ Those who think that this description underestimates the role of the third position of the line, still agree with the view of the subordination of the final position: 'to allow the second lift of the b-verse to alliterate in an

${ }^{279}$ Because of the difficulty of versifying prose in an alliterative mode, double alliteration in the a-verse in The Metres of Boethius occurs at little more than half of its usual rate.

${ }^{280}$ Hceto replaces fyr in line 49 for metrical reasons, a disyllable being required.

${ }^{281} \mathrm{Fyr}$ is carried over from the prose on fourteen occasions, at Metre 8.51, 11.43, 20.61, 83, $85,111,114,121,125,148,150,153,155,24.12$. Leg is added at 8.54, and 9.17. In 8.54, addition of fyr instead of leg would have created enjambed alliteration in an end-stopped structure, perhaps showing that the versifier did not casually seek this form of alliteration.

${ }^{282}$ See ASPR V, p. 238.

283 The alliterative enjambment and the envelope pattern might be seen as completed by the alliteration of 1.54 meahtum with 1.47 gemengeð metodes.

${ }^{284}$ For two passages in some ways comparable, see Christ and Satan ll. 263-6 with four lines of consecutive enjambed alliteration and 1l. 340-7 with five lines of it (ll. 340-1, 343, and 3467) in both of which there are also contrasting ideas of above and below, and (in the former) of the mixing of two elements, fire and air (in the abyss of hell).

${ }^{285}$ G. Russom, Old English Meter and Linguistic Theory (Cambridge, 1987), p. 73. Further evidence of the rule is the absence of accidental alliteration, (which occurs elsewhere in the line by chance and does so quite frequently), from this position: see Hoover, New Theory, pp. 68-9, and J. Taglicht, 'Beowulf and Old English Verse Rhythm', RES 12 (1961), 341-51, at 346. 
optional or ornamental manner would reduce the functionality of the first lift for establishing an alliterative pattern'. ${ }^{286}$ Licentious alliteration, in one way or another, involves this position in the alliteration of the line. Various different forms appear, although they have often been discussed together. C. R. Horn saw crossed and transverse patterns as contrary to the nature of the alliterative system, arguing that if the four stressed syllables of the line could not all alliterate together, then there should not be double alliteration across the line on dissimilar sounds. ${ }^{287}$ Because in his calculation such alliteration occurred less frequently than the laws of probability would predict, P. Frucht concluded that occurrences were accidental rather than artistic. ${ }^{288}$ Emerson closes an extensive critique of Frucht on a subjective note: if such patterning 'seems a pleasing ornament to a modern reader, it was probably pleasing to the poet and his hearers at a time when poetry appealed mainly to the ear'. ${ }^{289}$ Frucht's view, however, has been influential, possibly because Sievers accepted it. ${ }^{290}$ Amongst the more recent critics, Le Page too agrees with Frucht, stating that both the Beowulf-poet and Cynewulf 'avoided this feature', although he toys with (but then dismisses) the possibility that the 'poets made deliberate use of it in certain cases'. ${ }^{291}$ Bredehoft is broadly of the same view, computing that the Beowulf-poet is 'slightly biased against cross alliteration', but, because of a clustering of it at the start of the poem, concludes that for this poet and 'presumably in other poems as well' such alliterative patterning 'might best be considered as a useful (and usable) secondary poetic effect'. ${ }^{292}$ No settled general view has emerged. It will prove convenient to divide the analysis in to two sections.

\section{a. Secondary alliteration on the fourth position (crossed alliteration, $A B A B$ )}

Listing instances in Beowulf and comparing similar effects in Milton and Tennyson, J. Lawrence feels that 'whether the [Beowulf] poet sought for it or no, the crossed alliteration in these verses has a sensible æsthetic value'. ${ }^{293}$ Some share this view. ${ }^{294}$ Some haver. ${ }^{295}$ The third edition of Klaeber's Beowulf guardedly accepts it as ornament: 'it seems not unlikely that it was occasionally recognized as a special artistic form'. The fourth edition almost completely rejects it: 'such patterns, however, are almost certainly fortuitous...as they occur irregularly

${ }^{286}$ Suzuki, Metrical Organization, p. 314.

287 'Zur metrik des Heliand', BGdSL 5 (1878), 164-91, at 165-6. For examples, or apparent examples, of the alliterative structure AAAA, see below.

288 P. Frucht, Metrisches und Sprachliches zu Cynewulfs 'Elene', 'Juliana' und 'Christ' auf Grund der von Sievers Beit. X 209-314. 451-545 und von Luick Beit. XI 470-492 veröffentlichten Aufsätze (Greifswald, 1887), pp. 75-7.

${ }^{289}$ O. F. Emerson, 'Transverse Alliteration in Teutonic Poetry', JGP 3 (1900), 127-37, at 137. 290 Altgermanische Metrik (Halle, 1893), p. 41, § 41(d). For an overview of nineteenth century positions on this issue, see Emerson, 'Transverse Alliteration'.

291 Le Page, 'Alliterative Patterns’, p. 437.

292 Bredehoft, 'Estimating Probabilities', p. 21 ('cross' alliteration in his terminology covers both $\mathrm{ABAB}$ and ABBA alliteration).

${ }^{293}$ Lawrence, Chapters, pp. 38-53, at 41.

${ }^{294}$ See C. M. Lewis, 'Notes on Transverse Alliteration', MLN 16 (1901), 43-4, P. F. Baum, 'The Meter of the 'Beowulf', MP 46 (1949), 145-62, at 146-7, Orchard, 'Artful Alliteration', p. 432, Terasawa, Introduction, p. 18.

${ }^{295}$ See J. R. R. Tolkien, 'Prefatory Remarks on Prose Translation of 'Beowulf', in 'Beowulf' and 'The Finnsburg Fragment', trans. J. R. Clark Hall, rev. C. L. Wrenn (London, 1950), p. xxxvii: 'this is either accidental or a gratuitous ornament'; W. P. Lehmann and T. Tabusa, The Alliterations of the Beowulf (Austin, TX, 1958), p. 9, note that there are opposing views, but offer no opinion. 
and at a rate consonant with happenstance'. ${ }^{296}$ The fourth edition refers to Bredehoft in defence of this rejection, but Bredehoft himself has recently shifted position, arguing that crossed alliteration 'could operate functionally in a-lines where double alliteration is expected...this sort of substitution was a functional part of classical Old English practice'. ${ }^{297}$

If, in normal lines with four main stresses, crossed alliteration on the second and the fourth positions, and transverse alliteration on the first and the fourth occurred by happenstance alone, then we should expect, as Lewis long ago pointed out, the one type to occur approximately as frequently (or infrequently) as the other. ${ }^{298}$ That, however, is most definitely not the case. Transverse alliteration (ABBA) is much rarer than crossed alliteration (ABAB). In Beowulf, for example, there are thirty-five instances of the latter across four main stresses and but one (line 2615) of the former. In Genesis A, there are fifty examples of ABAB and not a single certain example of ABBA. ${ }^{299}$ Andreas has only thirteen instances of crossed alliteration, but no occurrence of transverse. In the corpus as a whole the simple type, ABAB, on fully stressed syllables in normal or hypermetric verse, occurs nearly five hundred times, or at a rate of about one in every sixty lines. ${ }^{300}$ Contrastingly, the simple type ABBA (again, on fully stressed syllables), occurs fewer than ten times, or about once every four thousand lines. ${ }^{301}$ The alliteration of the second and fourth positions of the line on a different sound from the alliteration of the first and the third does not disrupt the essential joint between the two verses, We may, accordingly, view crossed alliteration as an acceptable licence, for it does not appear that any rule of the system is actually broken by it, and, accordingly, Russom's formulation requires a slight modification: 'a weak constituent of a weak constituent may not contain the primary alliterating syllable'. Crossed alliteration provides a contrastive echo to the main alliteration of the line and sometimes its use does appear to be ornamental. ${ }^{302}$ However, the alliteration of the fourth position with the first, in place of the third position is dysfunctional, breaking the connection of the openings of the two halves of the structure, and subordinating the role of the third position. And alliteration of the fourth position alongside the third would, as Suzuki states 'attenuate the defining function of the penultimate lift' of the b-verse. ${ }^{303}$ The involvement of the final position of the line in its primary alliteration has no structural

296 See, respectively, Beowulf and The Fight at Finnsburg edited, with Introduction, Bibliography, Notes, Glossary, and Appendices, $3^{\text {rd }}$ ed. with First and Second Supplements, ed. Fr. Klaeber (Boston, 1950), p. lxx, and Beowulf, ed. Fulk, p. clxi.

${ }^{297}$ T. A. Bredehoft, Early English Metre (Toronto, 2005), pp. 60-1. In fact, about half of the small number of a-verses with single alliteration that he cites (which also participate in crossed alliteration) in defence of the idea of the adding of the one type of alliteration as a compensation for an absence of the other, do not require double alliteration in the typology of Bliss, so that the effect he discerns appears in the main to be a consequence of the looser model that he applies to the metre.

${ }^{298}$ Lewis, 'Notes', p. 44.

299 See below.

${ }^{300}$ See Appendix Five for a complete list of occurrences of crossed alliteration on stressed syllables. Note that the counts of some critics include alliteration falling on unstressed syllables: see, for example, Lehmann and Tabusa, Alliterations, pp. 128-34, W. P. Lehmann and V. F. Dailey, The Alliterations of the Christ, Guthlac, Elene, Juliana, Fates of the Apostles, Dream of the Rood (Austin, TX, 1960), pp. 35, 67, 124, 187, 229, 321, 374, 389, 401, Hoover, New Theory, pp. 85-6, Orchard, Companion, p. 60, n. 24.

${ }^{301}$ See below for complete lists.

${ }^{302}$ Rarely, also, it provides such an echo across the a-verse alone, e.g. Ex 61a mearchofu morheald, with consecutive hapax legomena.

${ }^{303}$ Suzuki, Metrical Organization, p. 324. 
justification and ought not to occur, except by scribal error, or modern editorial misunderstanding, or, perhaps, as the rarest and most risqué form of ornamentation. That its occurrence is, in fact, so very rare, confirms empirically what is true theoretically. The examples of it are examined in the next section.

What evidence, then, is there for the rhetorical use of crossed alliteration? If the end of Beowulf displays alliterative ornament (see, above), then it is not surprising that the opening does too:

\section{Hwæt! We Gardena in geardagum}

The crossed alliteration of the two nominal compounds balances the established licence of the alliteration of front and back $g$ - in first position (along with word-internal consonance in garand gear-) before the phonetically accurate alliteration of -dena and -dagum in the second. The first elements of compounds in the poetry are commonly less meaningful than the second ones for the first has the alliterative role that the second lacks, so the crossed alliteration of two second elements in sequence poetically highlights these elements, here foregrounding a foreign people and a past time. ${ }^{304}$ If the initial formulaic exclamation is stressed (as a traditional call for attention), then it is extra-metrical, ${ }^{305}$ and another unusual feature presents itself: exact repetition of metre across the line (Bliss type $\mathrm{d} 3 \mathrm{a}$, with suspension of resolution). No other line in the extant corpus shows both these features together (on compounds with different second elements). ${ }^{306}$ This opening, therefore, juxtaposes the conventional and the unusual: we know where we are in one way, but we are also intrigued in another.

Further light is cast by an example from The Battle of Maldon (lines 255-6):

Dunnere ba cwæð, daroð acwehte, unorne ceorl, ofer eall clypode. ${ }^{307}$

Dunnere's speech is not introduced with poetic verbs of speaking-mapelian or ge-melanwhich, perhaps, for the poet, were associated with speakers of high rank or great age. ${ }^{308}$ No formulas of speech introductions adorn these lines (such as wordum meelde, ageaf andsware). A normative dramatic motif is, however, in evidence: Dunnere speaks and simultaneously brandishes a weapon by way of defiance, as do all of those who speak (apart from Ælfwine), either raising their shield or shaking their spear, or both. ${ }^{309}$ This speech introduction is,

304 Compare, for example, the other two examples of consecutive compounds with crossed alliteration in the poem (39 hildewœpnum ond heaðowæedum, 1910 bundenstefna ofer brimstreamas) where the first elements are semantically redundant, or nearly so.

${ }^{305}$ If $h w c e t$ is stressed and part of the verse, then the line would have to alliterate on $h-$. In some instances in the corpus, speech-initial hwct must be part of the verse and unstressed (e.g. GenA 2643a, And 1376a) but, then, in such cases, it can hardly be exclamatory.

${ }^{306}$ With lexical repetition of the second elements and metrical repetition, note MCharm 2.524. In all instances without lexical repetition, a light verse of type $a$ or $d$ is combined with a whole-verse compound. Metrical variety across the line is the norm; see Bliss, Metre, Appendix E.

307 'Dunnere then spoke, brandished his spear, a simple peasant, he called over all.'

${ }^{308}$ Mapelian introduces the speeches of Byrhtnoð and Byrhtwold (both old, the first an ealdorman), ge-meelan those of Offa and Leofsunu; Byrhtnoð, Byrhtwold and Offa are clearly socially superior to Dunnere.

${ }^{309}$ Byrhtnoð (ll. 42- 3), Offa (l. 230), Leofsunu (1. 244) and Byrhtwold (ll. 309-10). Closest verbally is Byrhtwold's brandishing of his spear, l. 310b esc acwehte. 
however, highly unusual in its alliterative patterning. ABAB alliteration on main stresses continued across two lines occurs nowhere else in the poem and in only nine other places in the corpus. ${ }^{310}$ Continuation of it on the same alliterative sound in different words in the secondary position appears only once elsewhere. ${ }^{311}$ The first of these two lines also displays cluster alliteration on $c w$-, whilst the second shows the ancient poetic licence of $/ \mathrm{t} / /$ alliterating with $/ \mathrm{k} /{ }^{312}$ The effect is to draw Dunnere's rank as ceorl into closer connection with these verbs of speaking (cweðan, clypian) and his heroic act of defiance. Apart from his leader Byrhtnoð, a man very far above him in the social order, only Dunnere of all the Anglo-Saxon speakers cries out, and he calls over everybody. ${ }^{313}$ There is a suggestion, perhaps, of a social confidence at odds with his rank, or of a moral outrage that gives him voice beyond his station. ${ }^{314}$ An assertive peasant speaks for the first and only time in Old English heroic poetry. The sentiments he utters are quite consonant with those of others, imitative of them perhaps, but he is introduced in a way that characterises him as dynamic, brash even. ${ }^{315}$ Here too, then, crossed alliteration is found in a beginning - a speech introduction-and with a combination of traditional and innovative features on show.

The first of Judith's three speeches in Judith commences with an invocation to the Trinity couched in a cascade of extra alliteration (lines 83-6a):

Ic ðе frymða god and frofre gæst, bearn alwaldan, biddan wylle miltse pinre me pearfendre, ðrynesse ðrym. ${ }^{316}$

Both frymða god and frofre gæest occur elsewhere in the poetry as divine epithets-sometimes in lines with cluster alliteration-but only here are they combined felicitously into a line which then displays both cluster and crossed alliteration. ${ }^{317}$ If alwalda possesses secondary stress,

310 See Appendix Five. Honorific connotation is evident in GenA 1257-8 and El 717-18.

311 At Beo 2186-7; cf. also Rid 20.4-5a. In Wan 108-9, MCharm 2.47-51, the secondary alliterations fall on repeated words (læene, attor).

${ }^{312}$ See Brunanburh, ed. Campbell, p. 33: 'these two sounds are allowed to alliterate in the latest O.E. verse'; see, for example, Mald 76, and cf. Men 31 cyme: ceorlum. The licence survived for several hundred years: see H. Penzl, 'The Phonemic Split of Germanic $k$ in Old English', Language 23 (1947), 34-42.

${ }^{313}$ Ceallian introduces Byrhtnoth's response in 1.91 and seems to have been associated with shouting in battle; see E. G. Stanley 'Old English '-calla', 'ceallian', Medieval Literature and Civilization: Studies in Memory of G. N. Garmonsway, ed. D. A. Pearsall and R. A. Waldron (London, 1969), pp. 94-9, at 97. Clypode is used of the Viking messenger's speech in 1.25 as well as of Dunnere's here. The ceorl is, it seems, shouting loudly, but not in any way of itself associated with battle.

${ }^{314}$ That an act of calling or crying out over all may imply either that the speaker or the speech is authoritative, compare Sat 615, 625 (with crossed alliteration at 615), and the action of Guðere in Finn 22-3 who frcegn ofer eal undearninga.

315 This remains true whether unorne means 'simple' or 'pre-eminent', although the latter might affirm the characterisation suggested here. For the first, see Maldon, ed. Scragg, p.82; for the second, see J. Roberts, 'Old English un- 'very’ and Unferth', ES 61 (1980), 289-92.

316 'I will pray to Thee, God of creation, Spirit of comfort, Son all-powerful, Glory of the Trinity, for thy mercy in my need.' The translation is from Gordon, Poetry, p. 354.

${ }^{317}$ Frymða god occurs at GuthB 820b, El 502b, Jud 189b; frofre grest at ChristA 207b, ChristB 727a, GuthA 136b, GuthB 936b, Jul 724a. 
then line 84 also contains crossed alliteration of a subordinate sort (ABC AC). ${ }^{318}$ As line 86 certainly shows it, this may be the only example in the surviving poetry of crossed alliteration on the stressed syllables of different words across three consecutive lines. ${ }^{319}$ Since cluster alliteration appears also in line 86a, in a collocation that formulaically encodes this on quite numerous occasions in the poetry, ${ }^{320}$ there is also an envelope pattern of cluster alliteration. Hill sees this speech as the prime example of the form of the lorica in Old English poetry: in a moment of great danger, the Trinity is invoked by way of protection. ${ }^{321}$ He finds seven other instances of it in the corpus. ${ }^{322}$ None is inceptive, and only one line in these passages has crossed alliteration (ChristB 774). This instance also differs from all of the others in another important respect: Judith, an Old Testament heroine, yet knowingly speaks as if she were a Christian. It is true that the three children in the fire in Daniel and Azarias use three epithets for God which appear to adumbrate the Trinity, but as Hill points out, there is a difference between this and Judith's explicit naming of the three persons. ${ }^{323}$ Taking his lead from an Old Latin reading at the start of Judith's speech in chapter 13.7 (domine domine deus), ${ }^{324}$ and echoing Abraham's sublime anacoluthon in Genesis 18. $1-5,{ }^{325}$ the poet moves towards a spiritual reading of his heroine's speech: Judith addresses the three persons of the Godhead using a plurality of epithets alongside second person singular pronouns (83a ðе, 85a pinre). The gravity of the 'anomaly' ${ }^{326}$ stimulates from the poet the most extreme alliterative ornament.

There is only one context in the corpus where we can actually see a poet forging the crossed alliteration, in this case in an end rather than a beginning. Comparison of the close of Metre 13. 75-80 of The Metres of Boethius with its prose source allows examination of the versifier's verbal choices (with bold, italics, and underlining used as before):

${ }^{318}$ Bliss, Metre, p. 145, is inconsistent on the point, scanning it with secondary stress at Beo $928 \mathrm{~b}$, but without it at 955b. In his defence, he rightly points out that 'since the meanings of the two elements must have been present in the whole it should have secondary stress; but since the form of the first element has been reduced and obscured it should not' (private correspondence 1/8/1985).

${ }^{319}$ Excluding MCharm 2.45-54 which depends upon lexical repetition (of nygon, attre and geblced).

${ }^{320}$ See R. Frank, 'Late Old English prymnys "Trinity”: scribal nod or word waiting to be born?', Old English and New: Studies in Language and Linguistics in Honor of Frederic G. Cassidy, ed. J. H. Hall, A. N. Doane and D. Ringler (New York, NY, 1992), pp. 97-110: out of eight instances in the corpus, pryness collocates with prymm seven times.

${ }^{321}$ T. D. Hill, 'Invocation of the Trinity and the Tradition of the Lorica in Old English Poetry', Speculum 56 (1981), 259-67.

${ }^{322}$ In the order in which he analyses them: ChristB 771-7, Jul 722-9, Dan 399-403, Az 155-61, MCharm 11. 10-12, Pr 67-73, ChristA 348-58a.

${ }^{323}$ Hill, 'Invocation', p. 259 and n. 2.

${ }^{324}$ See Judith, ed. Griffith, pp. 74-5 and n. 257, and p. 183; and M. Griffith, 'The Sources of Judith (Cameron C.A.4.2)', Fontes Anglo-Saxonici: World Wide Web Register (http://fontes.english.ox.ac.uk).

${ }^{325}$ Where Abraham at the oaks of Mamre sees three men and, recognising the Trinity, addresses them in a mixture of singular and plural forms.

${ }^{326}$ The term is Hill’s, ‘Invocation’, p. 259. 
... and to bam heo swa hwearfað pæt heo eft cume pær heo $2 r$ wæs, $\underline{7}$ beo bæt ilce pæt heo œr wæs, ðоnесап ðе heo utan behwerfed sie bæt pæt hio ær wæs, and do pæt pæt heo ær dyde. $^{327}$

forðon hio swa hwearfað, pæt hio eft cume pær hio æror wæs, ponne hio ærest sie utan behwerfed. ponne hio ealles wyrd utan becerred, hio sceal eft don pæt hio ær dyde, and eac wesan pæt hio cror wæs. ${ }^{328}$

The passage is constructed around a sequence of repeated and mainly deictic adverbs (eft, ceror, lerest, utan, lealles, utan, left, cer, leac, cror), half of which the versifier adds to achieve the requisite alliteration (so forming one of the longest examples of continued vocalic alliteration in this text and in the corpus), all of which are followed by verbs. He passes over alliteration in his source which might easily have formed the primary alliteration of his verse-most obviously do and dyde-but which would have disrupted the grammatical parallelism, reserving this instead for ornamental use. ${ }^{329}$ The patterning culminates in two consecutive lines of crossed alliteration, each of which contains an infinitive and preterite of the same verb. The final verse-clause, line $80 \mathrm{~b}$, reiterates line $76 \mathrm{~b}$, but in the prose source these two were very nearly proximate, so that an envelope pattern has also been developed. The overall effect is mannered and seems quite deliberate.

\section{b. Primary alliteration on the fourth position}

This may be sub-divided into postponed alliteration (AA BA, or AB CA), transverse alliteration proper (AB BA) and hyper-alliteration (AB AA, or AA AA). In the first two, the final stress of the line alliterates with the first stress or with both stresses of the a-verse in preference to the first stress of the b-verse; ${ }^{330}$ in hyper-alliteration, it alliterates with the first and the third stresses, or with all three previous stresses. All violate the primary alliterative principle and ought not to occur, being unpoetic (in the way in which a breach of a grammatical rule would be 'ungrammatical'). ${ }^{331}$ Perhaps, very rarely, alliteration on

327 The text is from Chapter 25, B Text, Old English Boethius, ed. Godden and Irvine, vol. I, p. 294; ' .... and so turns that it may come again to where it was before and be the same as it was before, as soon as it is turned to where it was, and do what it did before.' The translation is from Old English Boethius, ed. Godden and Irvine, vol. II, p. 37.

${ }^{328}$ Metre 13, C Text, Old English Boethius, ed. Godden and Irvine, vol. I, p. 441; ‘ ... for, when it is first turned round about, it turns so that it may come again to where it was before. When it becomes turned around wholly, it must do again what it did before and also be what it was before.' The translation is from Old English Boethius, ed. Godden and Irvine, vol. II, p. 134. ${ }^{329}$ Note that the versifier frequently uses undisplaced finite verbs in structural alliteration.

${ }^{330}$ Light verses of type a or type e in the b-verse (such as GenA 1504, 2057, 2323, 2538, 2625, 2647, 2770, 2790, GenB 370, 574, Dan 122, 138, 410, 529, Sat 423, 617, Fates 23, GuthA 16, Soul I 117 Rid 4.8, 55.14, 59.12, 73.2, 91.6, etc.) are excluded from consideration here, as, of course, are the rare examples of postponed alliteration in the a-verse (of the form ABBC, such as Beo 3056a he is manna gehyld, with alliteration falling on gehyld).

${ }^{331}$ A comparative measure of the strength of the rule governing the absence of primary alliteration from the fourth position is gained from the behaviour of compounds which rarely stray into that location. Class One compounds are obliged to alliterate on their first elements and so their nature excludes them from the final position. Exceptions are few, but all fail to 
the final stress might occur as a kind of rhetorical anacoluthia, a rare breach of the rules for some particular artistic purpose, possibly indicating the emergence of a new poetics late in the period, or the otherwise hidden existence of some alternative poetics. The problem in isolating such rhetorical use is not, as it is with supererogatory alliteration, that of separating purposeful from chance addition. Rather, artistic licence needs somehow to be distinguished from the mistakes of scribes, the slips of poets, and the misunderstandings of editors. Traditional poetry was shown above to handle the use of rhyme in a consistent and rule-governed fashion, whilst non-traditional poetry in which rhyme is evidenced mainly does not. This distinction between 'classical' and 'non-classical' verse is relevant here too because both line-end rhyme and line-end alliteration involve the final stress, so that as the first group is careful in the use of the one feature, it should be surprising if it were not so in the case of the other.

In fact, once doubtful instances, or those susceptible to alternative explanation, are removed, ${ }^{332}$ none of these three kinds of licence is displayed much at all in traditional verse. The complete set of lines certainly violating the rule of the fourth position is as follows:

alliterate (see, in traditional verse, GenA 1119b, 2547b, Dan 464b, ChristB 516b, ChristC 912b, GuthA 40b, GuthB 1265b, Az 84b, 97b, Rid 40.70b, JDay I 102b, Beo 495b, Jud 211b). The structural rule governing the absence of alliteration is stronger than the lexical rule requiring it.

${ }^{332}$ Lines such as GenA 1601 freomen cfter flode, /and fiftig eac, pa he forð gewat, edited by ASPR with double alliteration in the b-verse (where the b-verse is clearly too long to be a normal verse), but interpreted by Bliss as a long line followed by an isolated a-verse, the two joined by continued alliteration, are excluded from consideration (see Bliss, 'Single HalfLines'). Also excluded are b-verses with alliteration on unstressed syllables or syllables with tertiary stress (e.g. ResA 34b peah pe latlicor) Postponed alliteration occurs in some contexts showing missing verses, or problems of lineation, or corruption (GenA 2046, Dan 460, Sat 89, 202, El 580), or a formula in the wrong order (GenA 10, 966), or the line alliterates correctly in another copy (Soul I 83). Two lines have an undisplaced particle that must be stressed and alliterate (Sat 106, Hell 50). GenA 2018b opens with a displaced finite which must be unstressed for metrical reasons. GenB 321b makes good sense and metre without godes, which is, presumably, scribal. Some apparent instances of transverse alliteration show an unstressed undisplaced finite verb, or other such particle, in first position in the a-verse alliterating with the final stress (e.g., with a verb: GenA 2153, Ex 197, Dan 124, 230, 541, And 225, 847, El 999, ChristB 577, ChristC 1227, Vain 30, Res 19, Wulf 16; with other particle: GenA 1530, El 911, ChristA 136, 255, 439, ChristB 516, Phoen 31, Beo 1222, 1294, 2377, 3164, Jud 331; for some further examples, see Stanley, Foreground, p. 135 and n. 41), or one heading the b-verse alliterating with the preceding stress (GenA 1858, Jud 61, 98); in one, the line occurs correctly in another copy ( $\mathrm{Az}$ 39, cf. Dan 322a); in another the manuscript makes no sense (Sat 462). Hyper-alliteration is apparent, too, in contexts with problems of lineation (Dan 207, 272, Sat 203, 458, 477, 667); in several others, there is a phonetic or scribal explanation (And 1627 with loss of $g$-, Soul II 103, Phoen 421, Wife 15 with unetymological $h$-, Rid 40.56 with metathesis (and cf. Rid 85.5), Beo 1151, 2916 with inorganic $h$-, 2296 with loss of - $h$ - between voiced consonants, Gifts 81 with w- for $h w$-). For discussion of Beo 1151, 2916, and other verses in the poem displaying 'trivialization of authorial lexemes', see L. Neidorf, The Transmission of 'Beowulf': Language, Culture and Scribal Behaviour (Ithaca, NY, 2017), pp. 65-6. In one verse, a single word has been edited as two (Dan 323). At various points, undisplaced particles create a semblance, but not the reality, of double alliteration in the b-verse (e.g. GenA 2864, Beo 1251, 1351, Jud 311). Editors, on occasion, have created double alliteration in the b-verse 


\begin{tabular}{|c|c|c|c|}
\hline \multirow[t]{6}{*}{ Postponed } & -ABA & Dan 202 & ne hie to pam gebede mihte gebædon \\
\hline & & Rid 3.36 & pæt me on bæce rideð \\
\hline & ABCA & Rid 40.5 & healdeð /ond wealdeð, swa he ymb pas utan hweorfeð \\
\hline & & Wife 4 & niwes oppe ealdes, no ma ponne nu \\
\hline & ABCCA & Sat 97 & Æce æt helle duru dracan eardigað \\
\hline & AABA & Sat 513 & meotod moncynnes ær on morgen \\
\hline \multirow[t]{2}{*}{ Transverse } & $\mathrm{ABBA}$ & Sat 503 & lange pæs ðe ic of hæftum ham gelædde \\
\hline & & Вео 2615 & brunfagne helm, hringde byrnan \\
\hline \multirow[t]{14}{*}{ Hyper- } & -AAA & $\operatorname{Res} A 29$ & Hæbbe ic ponne pearfe pæt ic pine, sepeah \\
\hline & ABAA & Sat 558 & feowertig daga folgad folcum \\
\hline & & Rid 40.86 & Nis under me ænig oper \\
\hline & & Jud 149 & of ðære ginnan byrig hyre togeanes gan \\
\hline & $\mathrm{ABA} A$ & GenA 1945b & Abraham wunode eðeleardum \\
\hline & ABACA & GenA 2529 & tiða weorðan. Teng ricene to \\
\hline & AAABA & Dream 9 & uppe on eaxlgespanne. Beheoldon pær engel dryhtnes ealle \\
\hline & -AAA & Вео 574 & Hwæpere me gesælde pæt ic mid sweorde ofsloh \\
\hline & AAAA & Jud 279 & his goldgifan gæstes gesne \\
\hline & AAAA & GenA 937 & adl unliðe pe pu on æple ær \\
\hline & & Ex 38 & frecne gefylled frumbearna fela \\
\hline & & Vain 76 & leofap in leahtrum, ne beoð ba lean gelic \\
\hline & & $\operatorname{Rim} 71$ & pæt ic grofe græf, ond pæt grimme græf \\
\hline & & $\operatorname{Res} B 80$ & gewitnad for bisse worulde, swa min gewyrhto wæron \\
\hline
\end{tabular}

There are just twenty two examples in over twenty thousand lines of this corpus of verse, or a rate of occurrence of just over $0.1 \%$; that is, almost all of the lines in traditional poems, $99.9 \%$, avoid primary alliteration on the fourth stressed position, and the scribes of the manuscripts either accurately copied non-alliterating words in the final position in their exemplars, or, if they made alterations, then they produced alternative versions that made sense and were acceptable in this respect. The validity of some of these very few exceptions has also been questioned. The coincidence in Dan 202, Sat 503 and Jud 149 of alliterative abnormality and metrical-grammatical irregularity suggests corruption (which may, or may not, be scribal in origin). ${ }^{333}$ Scribal error may account for others. GenA 2529b, for example, should almost certainly be corrected to teng $[e]$ ricene, with the preposition to then heading the next a-verse,

by misconstruing the mid-line boundary (e.g. FAp 18b fore prymme ðeodcyninges in Andreas and The Fates of the Apostles: Two Anglo-Saxon Narrative Poems, ed. G. P. Krapp (Boston, MA, 1906), p. 69.

${ }^{333}$ In Dan 202, there is either a breach of Kuhn's First Law (with mihte displaced, yet unstressed, and 202b a light verse), or postponed alliteration; if alliteration fell on mihte there would still be a breach of Sievers's Rule of Precedence (see D. Donoghue, Style in Old English Poetry: The Test of the Auxiliary (New Haven, CT, 1987) p. 9). On Sat 503, see Christ and Satan: an Old English Poem, ed. M. D. Clubb, YSE 70 (New Haven, CT, 1925), pp. 113-14: for the line to alliterate normally the finite lange ( $3^{\text {rd }}$ pers. sing. pres. subj. of impers. longian 'to cause longing') ought to be clause-initial and unstressed, but it is not. The syntax, as well as the metrical-grammar is unusual: 'the conjunction pet, introducing the clause which is the object of gemunde (i.e. ðœes mcenego-earde), has been left unexpressed'. Jud 149, on the other hand, shows a displaced particle which, yet, cannot be stressed: see Judith, ed. Griffith, pp. 26 and 42. 
to pam fcestenne. Disyllabic forms of weak, long-stemmed, singular imperatives are attested, ${ }^{334}$ and this a-verse phrase beginning with a preposition is quite frequently attested. ${ }^{335}$ Postponed and transverse alliteration can be amended by changing the order of the words, mainly in the b-verse. All instances have been improved in this way by some editors, ${ }^{336}$ but all, nonetheless, make sense as they stand. Only in the case of Beo 2615 is there reason other than the alliterative abnormality of the b-verse to support re-arrangement: brunfagne is the only compound in the poem in first position not to alliterate properly-but the manuscript order of the b-verse is supported by Beo 1245b hringed byrne. ${ }^{337}$ Hyper-alliteration could be corrected in a number of cases by changing the final stressed word or by reversing the order of the verses in ABAA alliteration. In four instances the first method is attractive. ASPR retains grce in Rim 71b, but as Macrae-Gibson points out ' there seems no sensible literary reason for the poet to have used the weak self-rhyme græf: græf here', particularly as he does not elsewhere use self-rhyme and as Old English has another common word with the same sense which rhymes with grce: scrcef. The rhyme is certainly improved by the substitution and Macrae-Gibson emends. ${ }^{338}$ Pope argues with force that Dream 9b 'violates the syllabic and alliterative scheme characteristic of hypermetric verses in this poem and elsewhere' and emends to engeldryhta fela. ${ }^{339}$ ResB 80b is metrically irregular, as well as alliteratively: Type 2A1 should not have anacrusis, and triple anacrusis is hardly to be found in traditional verse. Substitution of the Mercian present plural form earon for wceron corrects both metre and alliteration, and, arguably, improves the

${ }^{334}$ See Campbell, Grammar, §752 on the early and dialect forms of Class I weak verbs: 'In IWS, North., $R u^{1}{ }^{1}$, there is considerable fluctuation in the form of the imper. sg., $-e$ being sometimes added to long root syllables (e.g. Li. bilēore go)'; and also Genesis A, ed. Doane, p. 42: 'the poem was written at an early period in an Anglian, perhaps Northumbrian, milieu'.

${ }^{335}$ It is attested as a whole a-verse just a few lines later at GenA 2536a (and cf. And 1068b), but see, also, Sat 519a, And 1034a, 1544a, Jud 143a for the structure 'preposition + pam fcestenne' in traditional verse.

${ }^{336}$ Rid 3.36b rideð on brece: see ASPR III, p. 323, note to this line (but the rule of precedence requires a noun normally to precede a finite verb); Rid 40.5b hweorfeð utan: see ASPR III, p. 344, note to this line; Sat 97a duru helle and 513b on morgen cer: see Christ and Satan, ed. Clubb, pp. 10 and 116, respectively.

${ }^{337}$ See Kendall, Metrical Grammar, pp. 161-2. Reversal of the words in the b-verse was suggested by M. Rieger, 'Die alt- und angelsächsische Verskunst', Zeitschrift für deutsche Philologie 7 (Halle, 1876), 1-64, at 21.

${ }^{338}$ Riming Poem, ed. Macrae-Gibson, pp. 53 and 34, respectively; Exeter Anthology, ed. Muir, p. 266, also emends. The change was first suggested by E. Sievers, 'Zum angelsächsischen Reimlied', $P B B$ xi (1886), 345-54, at 354.

${ }^{339}$ See Seven Old English Poems, ed. Pope, pp 65-6 and, also, his The Rhythm of 'Beowulf': An Interpretation of the Normal and Hypermetric Verse-forms of Old English Poetry (New Haven, CT, 1942), p. 111. Swanton remarks that Pope's view 'ingeniously accounts for the entire MS line; insular $f$ and long $s$ are easily confused' (The Dream of the Rood, ed. M. Swanton (Manchester, 1970), p. 103). 
sense. ${ }^{340}$ A similar scribal error occurs in The Exeter Book at Sea 82a. ${ }^{341}$ GenA 1945b has a hapax legomenon showing the extra alliteration; probably another hapax form, eðelgeard, was the original form and has subsequently been miscopied. ${ }^{342}$ All four, however, make sense as they stand in their manuscripts, so that emendation is metri causa. ${ }^{343}$ No change of lexis quite convincingly normalizes Beo 574b. ${ }^{344}$ Inversion of the order of the verses in Sat 558 creates, or restores, correct alliteration; ${ }^{345}$ so, too, in Jud 149, although the metrical-grammatical irregularity remains. ResA 29 and Vain 76 appear to be motiveless slips. ${ }^{346}$

Very few of the verses in this brief list appear to display rhetorical motivation. GenA 937 participates in a host of alliterative enhancements in a carefully crafted speech of divine malediction. ${ }^{347}$ As pointed out above, Rid 40.86 occurs in a remarkable passage of interlaced alliteration. Slay attractively suggests that $E x 38$ shows crossed rather than hyper-alliteration,

340 There is certainly scribal error in this b-verse for min gewyrhto appears as mingie wyrhto. With the emendation, the metrical type is 3B1c, which is well attested. ResB 79b-81a then means: 'thus I have been severely punished in the eyes of the world, because my crimes are so great in the eyes of men' (here adapting the translation of A. J. Bliss and A. J. Frantzen, 'The Integrity of Resignation', RES 27 (1976), 385-402, at 398). The Mercian form of the plural is attested also in Kentish (see Campbell, Grammar, §768). ResB shows one Anglian word (fullestan, 93b), but is too short to provide much evidence of dialect origin (see Elegies, ed. Klinck, p. 15, and Resignation, ed. L. Malmberg (Durham, 1979), p. 7: 'no feature...affords any clue to the localization'))

${ }^{341}$ MS nceron may be a variant of nearon or naron, but most modern editors correct to nearon. The context demands the present tense, and this tense is attested too in the various versions of the homiletic prose analogue: Hwcer syndon nu pa rican caseras and pa cyningas, pe jo wcron (see Wulfstan. Sammlung der ihm zugeschriebenen Homilien nebst Untersuchungen über ihre Echtheit I Text und Varianten, ed. A. Napier (Berlin, 1883), p. 263, ll. 14-15).

${ }^{342}$ Holthausen, following Schröder, emends to eardgeard: see Die ältere Genesis, mit Einleitung, Ammerkungen, Glossar und der lateinischen Quelle, ed. F. Holthausen, Alt- und Mittelenglische Texte 7 (Heidelberg, 1914), p. 50, and E. Schröder, 'Steigerung und Häufung der Alliteration in der westgermanischen Dichtung I Die Anwendung alliterierenden Nominalcomposita', ZfdA 43 (1899), 361-85, at 370. On the underlying phonetic change, see Campbell, Grammar, §303: 'Some late texts have spellings which suggest a tendency for initial gea-, geo- and ea-, eo- to become identical in sound', and compare middaneard, wineard for middangeard, wingeard.

${ }^{343}$ Pope's claim that the reading of the manuscript in Dream 9b 'does not make sense' (Seven Old English Poems, ed. Pope, p. 65) is not correct: with ealle as the subject, translate 'all beheld there the angel of the Lord'. Rood, ed. Swanton, p. 103, finds this word order 'awkward', but subjects sometimes follow objects elsewhere in the poetry.

${ }^{344}$ See Beowulf, ed. Fulk, Appendix C, p. 335, §42(c) and E. G. Stanley, 'Unideal Principles of Editing Old English Verse', PBA 70 (1984), 231-73, at 269, for Holthausen’s suggested improvement of abreat for ofsloh. Reading, instead, ofstong for ofsloh would preserve the sense and correct the alliteration, and ofstong might, somewhat more plausibly than abreat, have been misread by a scribe as ofsloh; elsewhere the prefixed verb occurs only in prose, but note, with similar sense, syntax and metre, Mald 138b he mid gare stang.

${ }^{345}$ So Christ and Satan, ed. Clubb, p. 121: 'since the laws of alliteration demand some change...'.

${ }^{346}$ The poem's modern editor observes, with understatement, that 'it is not common to have four alliterating consonants in one line' (T. E. Pickford, 'An Edition of Vainglory', Parergon 10 (1974), 1-40, at 28).

${ }^{347}$ See Griffith, ‘Divine Speech’, pp. 72-3. 
the cluster alliteration in frecna and frum- subordinating that on $f$-in gefylled and fela (with these linked by consonance); ${ }^{348}$ this line is similar to And 1275:

$$
\text { swungen sarslegum. Swat yðum weoll }
$$

Here the a-verse has triple alliteration if the cluster alliteration across the line is not regarded as trumping the alliteration on $s-$. In each case, the heightened alliterative manoeuvre preserves the normality of the line structure, although double alliteration in each a-verse would normally have been expected by metre. Wife $4 \mathrm{~b}$ ought to alliterate on $m a,{ }^{349}$ but instead has postponed alliteration on $n u$ and so appears to link-at least phonetically-no and nu: the deserted or expelled woman tells us that she can relate her life 'no more than now'. This binding together of urgency and negativity is re-iterated in line 24 is nu swa hit no wcere, 'it is now as if it were not': mangled metre- but with emotional power. ${ }^{350}$ Perhaps, then, there are four lines in the entire corpus of traditional verse where poets have been prepared to sacrifice the usual rule for some stylistic gain. This picture changes significantly when we look at non-traditional verse.

The list of offending lines in non-traditional verse is as follows:. ${ }^{351}$

\section{Postponed alliteration}

(i) $-\mathrm{A}$ BA

PPs 64.8.3 for pinum wundrum forhte weorðað

73.19.2 beah pe wædla and pearfa he wyle

108.19.2 and gyrdelse ðe hine man gelome gyrt

125.3.1 Donne hi geond peode cweðað priste

139.11.2 ne bið se ofer eorpan gereaht ahwær

140.10.3 ne ascuf bu fram me sawle mine

Met 22.63 and mid hefinesse his lichoman

Finn 28 Đa wæs on healle wælslihta gehlyn

Mald45 "Gehyrst pu, sælida, hwæt pis folc segeð?

MSol II.359 "Ac forhwon ðonne leofað se wyrsa leng?

(ii) AA BA

PPs102.15.2 wunian widefyrh, ne him man syððan wat

Mald 288 Raðe wearð æt hilde Offa forheawen

(iii) AB CA

Exhort 74 siðe gesecan; pu scealt glædlice swiðe swincan

PPs 59.7.1 Cyninc ys me Iuda cuð

74.6.1 Forpon eastan ne cymeð gumena ænig

76.4.1 Swyðe ic begangen wæs and min sylfes gast

76.4.2 wæs hwonlice ormod worden

${ }^{348}$ D. Slay, 'Some Aspects of the Technique of Composition of Old English Verse', TPS (1952), 1-14, at 4, n. 2. Tolkien states that fela is 'wrong scripturally', and substitutes gehwylc following PPs 77.51, but this is pedantic on the one hand, and too bold on the other: see The Old English 'Exodus', Text, Translation, and Commentary by J. R. R. Tolkien, ed. J. TurvillePetre (Oxford, 1981), p. 38.

${ }^{349}$ Compare El 388b næfre furður ponne nu, 'never more than now' with alliteration on furður.

${ }^{350}$ Line 24, having only seven syllables, is short of one position, and, therefore, often supplemented.

${ }^{351}$ The alliterative rules of late verse differ in one respect from earlier verse: in the course of the tenth century, palatal /j/ and velar /g/ ceased to alliterate (see, Fulk, Old English Meter, pp. 258-9); accordingly, verses such as Mald 32b, 192b do not display double alliteration. Doubtful and ambiguous examples are excluded (but these are not here listed, being too numerous). 
92.4.1 Gearu is pin setl, and pu, ece god

138.10.2 burh pa onlihtest niht, pæt heo byð dæge gelic

Finn $41 \quad$ Hig fuhton fif dagas, swa hyra nan ne feol

(iv) $\mathrm{AB} C C \mathrm{~A}$

JDay II 169 synscyldigra, ceorfað and slitað

(v) BA CA

Instr 137 and eac Noe hæfde weoruldweolena genohne

Met 11.57 wyrta growan leaf grenian

24.16 faran betweox oðrum tunglum

Seasons 86 pæs be us boca dom peodlic demeð

\section{Transverse alliteration}

(i) AB BA

PPs 61.6.2 and fultum is; ne mæg ic hine ahwær befleon

JDay II 178 Wa pe nu, pu pe peowast pissere worulde

Seasons 100 sancte Petres preostas syppan

MCharm 2.58 Crist stod ofer adle ængan cundes

(ii) $\mathrm{AAB}$ BA

Instr $221 \quad$ Pu ful gearo pe ne wast wege pines gastes

Mald 75 wigan wigheardne, se wæs haten Wulfstan

PPs 58.10.1 Min se goda god, ætyw me pin agen god

\section{Hyper-alliteration}

(i) $-\mathrm{A} \mathrm{AA}$

PPs 75.8.2 eowrum pam godan gode georne

135.2.1 Eac ic andette pam pe ece is

Met 20.214 Hwilum ymb hi selfe secende smeað

20.221 ponne hio ymb hi selfe secende smeað

21.40 ponne wile he secgan pæt ðære sunnan sie

DAlf 23 ful wurðlice, swa he wyrðe wæs

MSol II.300 hio oferbideð stanas, heo oferstigeð style

KtPs 129 ðа ðu, ælmæhtig, æfre ne æwest

Thureth 8 pæs be he on gemynde madma manegaa

MCharm 2.34 pær geændade æppel and attor

(ii) AA AA

PPs 108.14.1 Eall pæt unriht pe his ealdras ær

CEdg 19 wintra on worulde, ða pis geworden wæs

$\operatorname{Pr} 18 \quad$ and a hys willan wyrcð; wel hym pæs geweorkes

MCharm 97 find pæt feoh and fere pæt feoh

(iii) $\mathrm{AB} A \mathrm{~A}$

PPs 103.17.1 Uphebbean hus hiora agen is

118.125.1 Ic eom esne pin; syle andgit, pæt ic

135.3.1 Andette ic swylce pam pe ealra is

148.13.1 Forbon his anes nama ofer ealle is

Met 19.23 hwite and reade and hiwa gehwæs

Mald $29 \quad$ "Me sendon to be sæmen snelle

MSol II.287 ac him on hand gæð heardes and hnesces ${ }^{352}$

${ }^{352}$ Presumably with loss of the aspirate; spellings of the adjective as nesce are attested (see DOE hnesce). 
II.299 wildne fugol. Heo oferwigeð wulf

Exhort 72 ymbe pinre sauwle ræd swiðe smeage

$\operatorname{Pr} 41$ hu pu mære eart, mihtig and mægenstrang

MCharm 11.2 wið pane sara stice, wið pane sara slege

(iv) AB AAB

MCharm 7.8 Ic benne awrat betest beadowræda

(v) -A BAA

MCharm 9.16 Eall he weornige, swa syre wudu weornie

(vi) AAB AA

MCharm 1.79 se god, se pas grundas geworhte, geunne us growende gife (vii) hypermetric AAB AAC

MSol II.368 leoftæle mid leoda duguðum; oðer leofað lytle hwile ${ }^{353}$

(viii) hypermetric ABC AA

MCharm 3.11 legde pe his teage an sweoran. Ongunnan him of pæm lande lipan

(ix) hypermetric AB AAA

MCharm 7.13 ne ace pe pon ma pe eorpan on eare ace

Sixty four violate the rule in just over ten thousand lines of verse, which is a rate of occurrence of $0.6 \%$, or six times the level in traditional verse-although more than $99 \%$ of lines remain normal in this respect. One is almost certainly corrupt: Met 11.57 where postponed alliteration appears in both verses. The first stressed word wyrta is found only in Junius's copy of the damaged manuscript and restoration of lencten from the underlying prose restores both alliteration and sense; ${ }^{354}$ the line then has crossed alliteration. Editors have viewed several others as probably corrupt. ${ }^{355}$ A few are also defective in either metre or metrical-grammar. ${ }^{356}$ The great majority, however, cannot readily be explained as the result of faulty transmission. Many of the lines with postponed alliteration could be corrected by reversing the order of the two stressed words of the b-verse, but this would leave unanswered the question as to why the scribes should mae so many errors of this sort in the copying of non-traditional poems by comparison with others.

Many of this group are better viewed as the consequence of changing poetics. Seven bverses with double alliteration-PPs 103.17.1, 135.2.1, 135.3.1, 148.13.1, Met 21.40, CEdg 19, DAlf 23-show the final stressed position alliterating on a part of the verb 'to be', a verb of low natural stress, and are, perhaps, evidence of the poets beginning to lose their sensitivity to accidental alliteration in the fourth position. This is clearest in the case of Met 21.40b pret ðœre sunnan sie where the words are taken from the prose ${ }^{357}$ the versifier had the opportunity

353 The line number is from ASPR, but the line is from Solomon and Saturn, ed. Menner, p. 98. ${ }^{354}$ See Old English Boethius, ed. Godden and Irvine, vol. I, p. 125 and n. 3, and 431 [lencten deð] growan.

${ }^{355}$ Exhort 74b is too long: see ASPR VI, p. 184, 'it may be that the text is otherwise corrupt at this point'; of Seasons 86, Sisam remarks 'it is doubtful whether line 86 is transmitted as the author wrote it' (K. Sisam, Studies in the History of Old English Literature (Oxford, 1953), p.51); PPs 73.19.2: 'Grein remarks that this line seems corrupt' (ASPR V, p. 214) for nothing in the Latin gives rise to the clause opening peah pe; Instr 137b opens with a self-alliterating compound.

${ }^{356}$ Both verses of PPs 59.7.1, 125.3.1b and Met 24.16a are short of one metrical position. PPs 58.10.1a and 118.125.1b show two displaced particles after the alliterating stressed elements; perhaps the latter is actually a light verse with the particles opening the dip of the next verse.

${ }^{357}$ Compare B 34.206, Old English Boethius, ed. Godden and Irvine, vol. I, p. 325. 
to alter the wording but did not to do so, either because he himself did not notice the error, or, noticing it, thought it not significant enough to merit change. The prose is implicated in a somewhat different way in two other offending verses in this text: Met 20 214b, and 221b, both of which come from lines alliterating on $s$ - which yet end with a finite form of smeagan, 'consider', ${ }^{358}$ the second borrowed from the prose, the first added to it. Smeagan, however, is a 'prose word', that is, one distributed in the surviving records with a statistically significant bias towards appearance in prose, and not in verse. ${ }^{359}$ Exhort 72 displays the same word in the same position. Mald 75b se wes haten Wulfstan displays another form of prosaism: in verse the normal idiom would be Wulfstan wces haten, with correct alliteration; ${ }^{360}$ the order where the clause opens with a demonstrative pronoun subject and the name follows the past participle is found frequently in prose, but only here in verse. Perhaps a prosifying scribe has wrongly inserted the idiom of that register; ${ }^{361}$ if these are the poet's words, then normal poetic form has been sacrificed for an uncertain gain. The influence of prose can, perhaps, be heard elsewhere in this group of exceptions. Finn 41 Hig fuhton fif dagas, swa hyra nan ne feol with its otiose subject pronoun and conjunction (otiose, anyway, in traditional verse) fails to convince as a line of heroic poetry, despite the sentiment. If this were Beowulf we should surely have expected a more laconic and paratactic construction such as * fuhton fif dagas, feol hyra nan. ASPR VI gives JDay II 178 as Wa pe nu, pu pe peowast pissere worulde, apparently with transverse alliteration, ${ }^{362}$ but the notes clarify that the manuscript of the poem has only Wa pe nu pu peowast and both the correction to the a-verse and the entire b-verse have been supplied from the prose homily which gives a close analogue of part of the poem and which here 'furnishes the correct reading'. ${ }^{363}$ This homily may look back to a prose source of the poem; the poem contains many prose words and as Stanley observes, the assumption that the prose is a corrupt rendering of the verse requires 'the assumption that a poem full of prosaic words happened to be turned into prose with the result that what looks unscannable and prosaic in the poem falls harmoniously into place when turned into prose'. ${ }^{364}$ All these instances of defective alliteration are linked in one way or another with the language and style of another register: the mode of prose appears to be interfering with that of verse. Late Old English shows the development of forms of prose which are in some ways poetic, so that there is other evidence to support the thesis that the two registers in late Old English are becoming less distinct. Part of this change appears to be a slight weakening of the near-complete control that earlier poets exerted over the end of their line. The fourth stressed position is becoming a little less subordinate to the other three.

In this situation, somewhat more prominent or exotic rhetorical use of this position might on occasion be expected. Hyper-alliteration accompanies a play on sounds (willa/wel) and words (wyrcð/geweorkes) in A Prayer 86, as part of a larger series of repetitions controlled

\footnotetext{
${ }^{358} \mathrm{Sm}$ - certainly alliterates with s- in Met 5.7 and 6.8.

${ }^{359}$ Stanley, 'Prosaic Vocabulary', p. 414.

${ }^{360}$ So GenA 1160b, 1240a, Sat 541b, Wid 34a, Beo 2602a, Met 26.56-7, KtPs 1a; but also in prose as well.

${ }^{361}$ The proliferation of demonstratives in the poem is certainly more characteristic of Old English prose than verse.

${ }^{362}$ For stress and alliteration on the undisplaced demonstrative in the phrase 'this world', where a contrast with the other world is implied, compare Wan 58b geond pas woruld.

${ }^{363}$ ASPR VI, p. 180. The prose is found in MS Hatton 113, and edited in Wulfstan, ed. Napier, no. XXIX, pp.134-43 (with this wording at p. 138, ll. 19-20).

${ }^{364}$ Stanley, 'Prosaic Vocabulary’, p. 390.
} 
by interlaced alliteration (as seen above). MSol II.298b-301 contain consecutive lines of hyperalliteration with word play too:

$$
\text { friteð æfter ðam }
$$

wildne fugol. Heo oferwigeð wulf, hio oferbideð stanas, heo oferstigeð style, hio abiteð iren mid ome, deð usic swa. ${ }^{365}$

No examples in traditional verse span consecutive lines, so that this is remarkable. ${ }^{366}$ Pope, however, suggests a re-ordering of the passage:

\section{friteð æfter ðam;}

wildne fugol heo oferwigeð, wulf hio oferbideð, stanas heo oferstigeð, style hio abiteð iren mid ome, deð usic swa ${ }^{367}$

The alliteration is now nearly normal (although line 299a must now be a singleton hypermetric verse with unusual double alliteration on the first and third stresses rather than the first two). The sense, however, is not improved: as Menner remarks, oferwigeð 'seems to go more fittingly with the wolf than with the bird', and outlasting rocks is rather more impressive than outlasting an animal. ASPR's division of the clauses, accordingly, seems preferable, although it is better not to close a sentence with line 299a, for there is a traditional poetic connection between birds and wolves which Solomon may be hinting at: even the beasts of battle, consumers of corpses on the battlefield, are themselves consumed by Age. And Age's surpassing strength and destructiveness is matched by an excess in the language (ofer-, ofer-, ofer-) and the style, with the rhyming of the verbs oferwigeð: oferstigeð and, more distantly, the near rhyming of friteð: oferbideð: abiteð, and the superfluity of the alliteration in juxtaposed b-verses.

A further pair of examples is provided by The Battle of Maldon:

"Me sendon to pe sæmen snelle, heton ðe secgan pæt pu most sendan raðe beagas wið gebeorge ${ }^{368}$

"Gehyrst pu, sælida, hwæt pis folc segeð?

Hi willað eow to gafole garas syllan ${ }^{369} \quad$ [1l. 45-6]

365 ، ... after that [Age] eats a wild bird. It overpowers the wolf, it outlasts stones, it surpasses steel, it bites iron with rust, does likewise to us'-the translation is from Shorter Poems, ed. Bjork, pp. 155-7.

${ }^{366}$ Note, also, PPs 76.4.1-2 with consecutive lines of postponed alliteration.

${ }^{367}$ From Solomon and Saturn, ed. Menner, p. 130: 'it consumes [the tree trunk] after that; it overcomes the wild bird, it outlasts the wolf, it surmounts rocks, it bites steel, iron with rust, does so to us'. Menner does not say where Pope suggests this lineation, but his Table of Abbreviations (p. 77) cites a transcript of MS A made by Pope in 1933.

368 'Bold seamen have sent me to you, told me to say to you that you are obliged quickly to send treasure in return for protection...'

369 'Do you hear, seafarer, what these people are saying? They intend to give you spears as tribute...' 
Byrhtnoð's reply to the Viking imitates some of the messenger's words (but rejects their meaning). ${ }^{370}$ This acerbic combination of similarity and contrast is seen from the start of the two speeches. In their openings, both are, or purport to be, reports of the speeches of others, of the larger forces that stand behind these mouthpieces, ${ }^{371}$ the one boldly demanding protection money, ${ }^{372}$ the other apparently spoiling for a fight. There is some repetition of lexis: scemen: scelida, secgan: seged. The hero reiterates the sibilance of the messenger: both speeches open with alliteration on $s$ - (which is much less frequent as an alliterative sound in this poem than is normal, so that its recurrence is the more noticeable). ${ }^{373}$ A much more extraordinary similarity, however, is that the last stress of the first line of each speech 'incorrectly' participates in its alliteration, with hyper-alliteration in line $29 \mathrm{~b},{ }^{374}$ and postponed alliteration in line $45 \mathrm{~b} .{ }^{375}$ Given that there are several Old English words meaning 'keen' or 'bold' or 'brave' which the poet could have used in place of $29 \mathrm{~b}$ snelle ${ }^{376}$ some of which are attested in the poem (caf, cene, modig), and which would not have caused an alliterative problem, and given that the poet could easily have used flotmann in place of 45a scelida, in order to alliterate normally with 45b folc, ${ }^{377}$ this exact correspondence of licence appears to be contrived and integral to the network of similarities between the two utterances. It is certainly not the case that Maldon, despite its alliterative abnormalities, contains many such lines: apart from line 75b discussed above, only 288b certainly exhibits alliteration on the fourth position. ${ }^{378}$ No other speech in the poem begins with an alliterative irregularity. The hero, it seems, echoes too this feature of the messenger's speech, and the similarities of the speeches are surely engendered in order to encourage their close comparison—so much, after all, hangs upon these words.

${ }^{370}$ E.g. l. 32 ge pisne garrces mid gafole and 46 eow to gafole garas, 40 mid pam sceattum us to scype gangan and 56 mid urum sceattum to scype gangon.

${ }^{371}$ The messenger at first seems to refer to the Vikings as if he were not one of them-in order, perhaps, not to alienate his audience-but the transition to the first person plural we in lines $35 \mathrm{a}$ and 40a makes clear the truth of the matter.

${ }^{372}$ It is quite possible, as B. Mitchell points out, that the sense here of motan + infinitive may instead 'in view of the context be ironical- 'you have our gracious permission to"'; see his Old English Syntax (Oxford, 1985), vol. I, §1016. Whether open or disguised, the Vikings' message remains clear enough, and Byrhtnoð was surely certain to be enraged by either formulation.

${ }^{373}$ Elsewhere in the poem only at 1l. 30, 38, 59, 115, 118, 134, 159, 177, 278, 282 (?rhyme), 298 , giving a rate of occurrence of $4 \% .10 \%$ is the average across the corpus. If $s w$ - here only alliterates with itself (as in ll.115, 118), then $s$ - alliteration occurs even more sparingly.

${ }^{374}$ For the suggestion that $s$ - clusters in Maldon alliterate only with themselves, see C. E. Bazell, 'Notes on Old English Metre and Morphology: I. A Peculiarity of Alliteration in the Battle of Maldon', Wortbildung, Syntax und Morphologie: Festschrift zum 60. Geburtstag von Hans Marchand, ed. H. E. Brekle and L. Lipke (The Hague, 1968), pp. 17-18. Maldon, ed. Scragg, p. 52, n.136 states: 'that $s+$ vowel does not alliterate with $s n$ is shown by 29', but this is to allow position to trump phonetic fact. Snell is the sole word in the poem beginning with this cluster.

${ }^{375}$ See Maldon, ed. Scragg, pp. 70-1: 'the alliteration scelida: segeð is unacceptable since segeð is the fourth lift, and emphasises a verb above the noun folc'. The line cannot alliterate on $h$-, for then an undisplaced finite verb alliterates in preference to a compound noun in the a-verse, and the b-verse must then have three stresses instead of two.

376 See Roberts, Thesaurus, I, pp. 400-1,

${ }^{377}$ Cf. flot 'sea', l. 41, flota 'seaman', ll 72, 227.

${ }^{378}$ For discussion of the problem at 1.288 , see Griffith, 'Alliterative Licence', pp. 60-79. See above for the possibility of postponed alliteration in Mald 183b. 
The final cluster of more complex examples are all (with one exception) from The Metrical Charms in which hyper-alliteration occurs the most frequently-and they point to the end of the road for the normal structure. The Charms display a wide range of egregious departures from normal alliteration, metre and metrical-grammar. The poetic portion of Charm 7 For the Water-Elf Disease may serve as a brief illustration (lines 8-13):

\author{
Ic benne awrat betest beadowræda \\ swa benne ne burnon, ne burston \\ 10 ne fundian, ne feologan, \\ ne hoppettan, ne wund waxsian, \\ ne dolh diopian; ac him self healde halewæge, \\ ne ace pe pon ma, pe eorpan on eare ace. ${ }^{379}$
}

What we are seeing is the death of the normal rules governing the fourth position of the line, or the emergence of a different poetics in which the difference of final position is no longer relevant. No line passes muster. Lines 9 and 10 do not have a second position in the b-verse. ${ }^{380}$ Lines 8 and 12 have a compound beginning in the second position of the b-verse and, therefore, also have a third position in this verse. The final line has three separate stressed words in the b-verse and triple alliteration! Three lines, 8, 11 and 12, display double alliteration in the bverse, the last two of which alliterate on a different sound from the alliterations of the a-verses, so that there is no firm evidence that these two do indeed belong to lines of alliterative poetry. ${ }^{381}$ Overall, there is more alliteration in these b-verses than there is in the a-verses, and no compound appears in its proper place. The laws of traditional verse have been abandoned, or suspended, or superseded in this mode of medicinal poetry. As BM Royal MS 12D, which contains this charm, is dated to the middle decades of the tenth century-some time before the battle of Maldon took place-no simple chronology of the development of the traditional line from normality towards deviation can be drawn. ${ }^{382}$ Some other factor or factors must also have been in play. If this is partly a matter of genre, then the poetics of gealdor were simply different from those of leoð or gied. ${ }^{383}$ The alliterative patterns here may have ornamental function, but

379 'I have bound on the wounds the best of war-bandages, that the wounds may neither burn nor burst; may they go no further, nor spread, nor jump about, may the wounds not increase, nor the sores deepen. For I protect him with health-giving water. Then it will pain you no more than it pains the earth in your ear'. The translation is from Anglo-Saxon Magic, ed. G. Storms (The Hague, 1948), p. 159.

${ }^{380}$ Assuming that feologan has a short stem, as appears to be the general view.

${ }^{381}$ Lines in normal verse with this alliterative structure are extremely rare and are probably scribal errors; see, for an example, GenA 1143 him cefter heold pa he of worulde gewat (Genesis A, ed. Doane, p. 320, suggests reading weold for heold). Middle English examples (such as The Three Foes of Man, line 15, and De Tribus Regibus Mortuis, line 18) occur in alliterative verse where line structure is defined also by rhyme and by stanzaic form: see A. T. E. Matonis, 'Middle English alliterative poetry', So meny people longages and tonges: philological essays in Scots and mediaeval English presented to Angus McIntosh, ed. M. Benskin and M. L. Samuels (Edinburgh, 1981), pp. 341-54, at 344-5.

382 The dating is Ker's. See N. R. Ker, Catalogue of Manuscripts containing Anglo-Saxon (Oxford, 1990), p. 332,

${ }^{383}$ Similarly, in late Middle English alliterative poetry, some poems strictly observe the rule of the fourth position (e.g. Purity and Patience), whilst others of much the same date are more licentious (Borroff, Metrical Study, p. 233, n. 23, counts 23 occurrences of AABA in GGK). 
the effect, whatever it might be, does not appear to stem from contrast with the prosodic norm. ${ }^{384}$

\section{Conclusion}

Supererogatory alliteration and the licence of crossed alliteration occur commonly and are quite frequently used by the poets for stylistic ends. Alliteration which violates the rule of the fourth position is exceedingly rare and found in rhetorical use even more rarely. At one extreme-with double alliteration in the a-verse-ornament is wrapped together with functionality; at the other extreme-with double alliteration in the b-verse-rhetoric is hard to disentangle from error and corruption. The former marks the re-iteration of formal structure; the latter its abandonment. The above sections have focussed largely on the uses of the various types of extra alliteration as individual ornaments where they occur in the corpus separately from one other, and, in particular, on examples which show patterned sequences or remarkable groupings of these types and/or which use the less common word-initial sounds. Appendix Six gives a guide to the overall level of occurrence of most of these types across the corpus (excluding very short poems). The extensive use of cluster alliteration in The Riming Poem and its systematic use in Beowulf appear, in their different ways, to be unique. Riddle 40 stands out for its generous use of interlaced and continued consonant alliteration. The Metres of Boethius makes especially free use of continued vocalic alliteration. Many, but not all, of the most extended, or unusual, examples of continued, interlaced, enjambed, and crossed alliteration appear in later or non-traditional poetry, and especially in The Metres of Boethius, Judith, The Metrical Psalms, and The Battle of Maldon, which are also the poems (together with The Battle of Brunanburh) displaying the greatest overall quantity of occurrence of all of these types. It is also in these poems and in others found in ASPR VI that most of the few instances of postponed, transverse, and hyper-alliteration are to be found, with the wildest examples displayed by The Metrical Charms. ${ }^{385}$ Some of the shorter poems of The Exeter Book also figure prominently in their use of extra alliteration (OrW, Rim, Pan, Whale, Rid 3).

Five principal types of use, mainly stylistic, of extra alliteration have been isolated, two of them specific to a type of alliteration, three of them general:

a. in the case of double alliteration on consonants in the a-verse, as a regular reaffirmation of the structure of the line as shown by its use as a counterbalance in traditional verse to verse-end rhyme

b. in the case of cluster alliteration, as an exploitation and development of phonaesthemes of the Old English language

c. as a structuring device linking ideas, or dramatic moments in a plot, or sections in a design, or parts of a whole, or marking out beginnings or ends

d. as an instrument of mimesis, with poetic sound imitating real sound, or, as an attempt to replicate stylistically the structure of key ideas

e. as an honorific marker of respect, either for the divinity, or for those of the highest social status.

\footnotetext{
${ }^{384}$ And, accordingly, hyper-alliteration in The Charms does not lie directly behind the Middle English inheritance of it. Its use, for example, in continued lines in GGK 2077-82 (part of the description of Gawain's approach to the Green Chapel) has an effect which depends entirely on the departure from the normal alliterative structure.

${ }^{385}$ But it should also be noted that amongst the poems with the least commitment to extra alliteration are found some poems that are late or non-traditional: Men, Seasons, and LPr II.
} 
In practice, of course, the various sorts of extra alliteration often occur in the corpus in combination in passages (sometimes along with other devices) where any one or more of these effects is evident. ${ }^{386}$ In Genesis A, as I have tried to show elsewhere, the poet ornaments the most important divine speeches to a much greater extent than any other speakers' words, with honorific intent and, perhaps, as an attempt to characterise the word of God as the vox tonantis. ${ }^{387}$ Cluster alliteration, common in Judith, participates there, with other stylistic features, in passages of sound effects which appear to be designed mimetically. ${ }^{388}$ Orchard shows how artful alliteration on unstressed syllables connects together the parts, or the opening and closing, of riddles, by which method, for him, 'entire Riddles' are 'effectively defined' ${ }^{389}$ Another set of examples provides very obvious illustration of how multiple ornamental features on stressed syllables clarifies the mode and structure of a poem. The majority of all the supererogatory features of alliteration in The Panther are grouped in four short passages which are paired as two binaries, for the same reason in each case:

Se is æghwam freond, duguða estig, butan dracan anum, pam he in ealle tid ondwrað leofap purh yfla gehwylc pe he geæfnan mæg. ${ }^{390}$ [ll. 15b-18]

Æfter pære stefne stenc ut cymeð of pam wongstede, wynsumra steam, swettra ond swipra swæcca gehwylcum, wyrta blostmum ond wudubledum... ${ }^{392}$

$$
\text { [11. 44-7] }
$$

Swa is dryhten...eallum eaðmede... duguða gehwylcre, butan dracan anum, attres ordfruman. $\quad$ pæt is se ealda feond pone he gesealde in susla grund... 391

$$
\text { [11.55a, 56a, 57-9] }
$$

“...god ungnyðe pe us to giefe dæleð ond to feorhnere fæder ælmihtig, ond se anga hyht ealra gesceafta uppe ge nipre.” $\quad$ pæt is æpele stenc. ${ }^{393}$

[1l. 71-4]

The first passage (15b-18) tells us of the only enemy of the panther, the serpent or dragon, and the second (57-9) provides us with the symbolic meaning of this poisonous creature, the old enemy, Satan. The third passage reveals that a sweet fragrance emanates from the panther's resting-place, which in the final passage is interpreted (via a Pauline allusion) ${ }^{394}$ as salvation itself. The first and third passages offer us important details about the panther which are then explained (58b, 74b Pret is...) in the second and fourth passages from the fairly short allegorical conclusion to the poem (1l. 55-74). The repeated b-verse butan dracan anum (along with shared primary alliteration on duguða in the a-verse) explicitly connects the language of the first two passages. Perhaps, too, rhyme and word-play associates freond and feond. In each, also, however, there is a concentration of extra alliteration which is not a consequence of the lexical

\footnotetext{
${ }^{386}$ Appendices One, Two, Three, and Four (below) list combinations of cluster, continued, enjambed and crossed alliteration.

387 See Griffith, 'Divine Speech'.

388 Judith, ed. Griffith, pp, 66-7, 84-7.

389 Orchard, 'Artful Alliteration', pp. 436-7.

390 'He is a friend to all gracious in his favours, except the serpent alone, with him he lives in perpetual hostility because of all the evils which he can perform.'

391 'Just so the Lord is...gentle to all...to every people, except the serpent alone, origin of poison. That is the ancient fiend whom he tied in the gulf of torments.'

392 'After the voice an aroma comes out from that place, a more pleasing breath, sweeter and stronger than every smell, blooms of flowers and blossom of trees...'

393 ،....generous grace that the Father Almighty shares with us as a gift and life-saver (and the one hope of creatures above and below); that is the noble aroma.'

${ }^{394}$ Ephesians 2.7-9, and see Physiologus, ed. Squires, pp. 21 and 68.
} 
repetition, and which, yet, is very precisely organised. In both, there is enjambed vocalic alliteration beginning with anum at the end of lines 16 and 57-which continues in the first passage to the end of line 18. In both, there is also crossed alliteration (in lines 16 and 58). No shared lexis other than stenc links the third and fourth passages, but both again show concentrations of supererogatory alliteration. In the third passage, crossed alliteration occurs twice (ll. 45 and 47), in both cases on consonant clusters (st-, bl-), the first of which continues the alliteration of the preceding line. The coinciding of cluster and crossed alliteration is very rare in the poetry: the occurrence of it twice in three lines is unique, and the intervening line (46) also shows cluster alliteration on the three alliterating stresses across the line (on $s w$-). ${ }^{395}$ The final passage echoes the first and third in its display of enjambed vocalic alliteration, which, as with the first passage, extends into continued alliteration which closes the poem. Twelve of the twenty instances of extra alliteration in the poem are found in these few short passages (which form less than a fifth of the poem). ${ }^{396}$ The two particular parts of the allegorical picture of the panther that the poet picks out for the most explicit symbolic decoding are highlighted by these concatenations of sound both in the picture and in the interpretation.

There is, then, a wealth of evidence that the poets used alliteration ornamentally in addition to their functional use of it, and modern critics need to be more alert to these rhetorical patterns, not just in terms of the appreciation of the meaning of individual passages, or of the predilections of individual poets, but also in terms of the larger relationships between extra alliteration and other stylistic and syntactic patterns. Phonaesthemes, in particular, cry out for fuller appreciation. Very rarely indeed, however, did traditional poets violate the rule governing the absence of primary alliteration from the final position of the line, for this ultimately defined the line as a line.

Mark Griffith

New College

Oxford

395 See Appendices One (section 4) and Five.

396 These instances are (with those in the discussed passages in bold italics): with cluster alliteration, ll. 39, 41, 45 (in crossed alliteration), 46, 47 (in crossed alliteration), 55, 61; with continued alliteration, ll. 17-18, 34-5, 73-4; with enjambed alliteration, ll. 3-4, 10-11, 16-17, 57-8, 61-2, 72-3, with crossed alliteration, ll. 16, 45, 47, 58. 


\section{Appendices}

In these appendices, line references are to ASPR (except for Instr). Except where a poem contains only a single occurrence, the total incidence in it of a given feature is noted in brackets after the abbreviated title with ' $x$ ' standing for 'times'. Alliteration on unstressed syllables and on syllables bearing only tertiary stress is ignored.

\section{Appendix One: Cluster Alliteration in Old English Poetry}

Alliteration on $s c-$-, sp-, st- is excluded (except in sub-section $\mathbf{2 d}$ below), but not alliteration on scr-, spr-, str-. A line reference alone denotes cluster alliteration in at least two stresses across the two verses of the line. A line number followed by 'a' indicates that both stresses in the averse share the same cluster, but this is not carried over into the b-verse. A line reference in bold means that all three alliterating stresses of the line display the same cluster. A line reference in italics indicates that two stresses alliterate on the cluster and a third alliterating stress shows consonance (e.g. GenA 19 firena fremman, ac hie on friðe lifdon).

\section{1a) by text}

GenA (107x): 5 (fr), 9 (sw), 14 (bl), 19 (fr), 23a (dw), 40 (dr), 46 (gr), 61 (gr), $73 a$ (hl), 79 (fr), 81 (dr), 132a (fr), 134a (sw), 142 (dr), 190 (dr), 192 (bl), 200 (br), 861 (dr), 884 (fr), 907 (br), 938 (sw), 943 (fr), 954 (fr), 963 (fr), 968 (fr), 976 (br), 983 (fr), 1008 (br), 1045a (fr), 1072 (fr), 1081a (sw), 1102a (gr), 1108a (fr), 1137a (gr), 1142 (fr), 1183 (fr), 1189a (fr), 1217 (pr), 1222 (fr), 1255 (fr), 1275 (gr), 1289 (br), 1308 (br), 1326 (sw), 1375a (sw), 1386 (fl), 1414a (sw), 1427 (fr), 1475 (fr), 1492 (br), 1493 (fr), 1582 (hl), 1597 (fr), 1618 (fr), 1642 (fr), 1693 (hl), 1708 (fr), 1711 (fr), 1760 (fr), 1761 (bl), 1764 (sw), 1813 (br), 1818 (dr), 1825 (wl), 1834 (fr), 1843 (fr), 1848 (wl), 1866 (br), 1903a (wr), 2033 (br), 2038a (wr), 2063 (gr), 2098 (fr), 2130 (fr), 2176a (fr), 2194a (br), 2219a (fr), 2255a (dr), 2284 (dr), 2332a (fr), 2333 (bl), 2335 (br), 2343 (br), 2371 (fr), 2417a (sw), 2543 (sw), 2554a (br), 2559 (sw), 2579a (fr), 2621 (br), 2639 (br), 2659 (sw), 2672a (sw), 2690 (fr), 2737 (fr), 2747 (fr), 2765 (br), 2782 (dr), 2802a (br), 2805 (dr), 2812 (fr), 2820 (fr), 2837 (fr), 2858 (sw), 2892 (br), 2929 (br), 2932 (br); GenB (13x): 248 (tr), 257 (dr), 284 (str), 302 (gr), 325a (br), 384a (gr), 390a (gr), 391a (sw), 407a (gr), 485a (dr), 529 (sw), 638a (dr), 793 (gr); Ex (12x): 34 (dr), 38 (fr), 79a (dr), 269a (br), 274a (fr), 309a (sw), 312a (gr), 330a (gr), 338 (fr), 355 (fr), 363 (pr), 547 (dr); Dan (21x): 35 (fr), 61a (str), 178 (hl), 185 (fr), 213 (pr), 214 (fr), 241 (hr), 257a (dr), 261 (fr), 281 (dr), 303a (fr), 321 (br), 341 (sw), 348a (dr), 380 (bl), 424 (pr), 438a (gr), 465 (fr), 528 (sw), 670a (hr), $755 a$ (hr); Sat (16x): 44 (dr), 68 (dr), 82 
(dr), 111 (fl), 173 (dr), 186 (dr), 230 (dr), 255a (dr), 258a (gr), 268a (gr), 313 (dr), 392 (dr), 501 (pr), 670 (br), 700a (gr), 707a (gr); And (58x): 34 (dr), 51 (br), 72a (sw), 73 (dr), 107 (br), 209a (br), 217a (gr), 245a (pr), 254 (gr), 267 (sn), 273 (br), 312 (hl), 313 (dr), 369 (dr), 374 (str), 376a (pr), 425a (gr), 504 (br), 513 (br), 519 (br), 556 (fr), 622 (fr), 629 (fr), 739 (hl), 768 (br), 776a (gr), 841a (hl), 874 (dr), 917a (gr), 934 (fr), 951a (gr), 1003a (dr), 1009 (sw), 1021a (cl), 1118a (br), 1128 (fr), 1139 (pr), 1151a (dr), 1163 (fr), 1262 (bl), 1264 (pr), 1275 (sw), 1281 (dr), $1306 a$ (br), 1360 (hl), 1391 (pr), 1432 (fr), 1441 (sw), 1449 (bl), 1471 (wl), 1546 (fl), 1573 (fl), 1574 (br), 1580 (str), 1590 (gr), 1685 (pr), 1705 (fr), 1710 (br), 1719 (bl); Fates (4x): 12a (fr), 18a (pr), 91 (fr), 109a (fr); Soul I (2x): 17 (dr), 45a (str); Dream (7x): 20a (sw), 23a (sw), 76a (fr), 84a (br), 140 (dr), 144 (dr), 149a (bl); El (40x): 81 (dr), 88 (fr), 123a (pr), 151 (pr), 154 (sn), 177 (pr), 185 (pr), $238 a$ (br), 244 (br), 313 (sn), 324 (cw), 329 (pr), 371a (dr), 387 (wr), 443 (fr), 447 (sw), 483 (pr), 494 (pr), 510 (br), 519 (pr), 542 (fr), 616 (hl), 674 (wr), 696 (cl), 704 (pr), 759a (gr), 765 (dr), 834a (gr), 841a (br), 858 (pr), 883 (pr), 1045a (br), 1067 (fr), 1094 (br), 1163 (fr), 1181a (wr), 1238a (br), 1276a (br), 1286 (pr), 1298 (pr); ChristA (12x): 14 (hr), 87 (cw), 148 (cw), 207 (fr), 223 (fr), 225 (fr), 288 (pr), 357a (br), 380 (br), 388 (pr), 405a (dr), 416a (wr); ChristB (16x): 489 (fr), 507 (fr), 522 (fr), 575 (fr), 580a (dr), 588a (fr), 593a (pr), 594a (dr), 599a (pr), ${ }^{397} 643$ (fr), 676a (fl), 726 (pr), 745 (hl), 831 (wr), 839 (fr), 858a (hr); ChristC (30x): 877 (bl), 891 (cw), 954 (sw), 958 (cw), 969 (pr), 970 (gr), 991 (br), 1003 (gr), 1023a (pr), 1058 (br), 1108 (dr), 1133a (pr), 1204 (gr), 1256a (bl), 1267 (pr), 1274 (dr), 1290 (fr), 1299a (sw), 1340 (fr), 1346a (bl), 1348a (sw), 1391 (bl), 1408 (dr), 1411 (sw), $1445 a$ (pr), 1508a (dr), 1526a (gr), 1530 (sw), 1641 (dr), 1644 (dr); GuthA (30x): 14 (dr), 123a (dr), 181 (fr), 223 (cw), 259 (dr), 283 (hr), 335a (br), 341 (dr), 343a (sl), 375a (gr), 386 (dr), 411 (fr), 452 (sw), 453 (fr), 464 (dr), 497 (bl), 558a (wr), 570 (sw), 571a (gr), 608 (bl), 625 (sw), 626a (dr), ${ }^{398} 646 \mathrm{a}$ (pr), 654a (br), 680 (dr), 684 (dr), 715 (dr), 727 (dr), 740 (dr), 804 (br); GuthB (25x): 820 (fr), 830a (dr), 883 (br), 888 (fr), 901 (dr), 906a (hr), 910 (br), 964 (br), 1021 (fr), 1083 (dr), 1101a (dr), 1103 (br), 1125 (sw), 1144 (fl), 1166 (sw), 1198 (br), 1211 (fr), 1273a (sw), 1318 (sw), 1325a (br), 1335a (gr), 1349a (dr), 1350 (pr), 1357 (hl), 1374a (bl); Az (15x): 3 (dr), 24a (fr), 38 (br), 59 (sw), 64a (dr), 85 (hl), 97 (fr), 102 (dr), 107 (br), 111 (bl), 116 (br), 137a (cl), 142 (br), 161 (br), 180 (br); Phoen (40x): 12 (hl), 16 (hr), 21a (bl), 25 (hl), 60 (hr), 67a (br), 68a (pr), 78 (gr), 84 (fr), 124 (sw), 126a (br), 137 (sw), 138 (dr), 144 (pr), 186a (sw), 199a (sw), 214 (sw), 226 (cl), 229 (br), 239 (fr), 277a (cl), 283 (br), 294a (wr), 315a (sw), 317 (sw), 341a (br), 348a (dr), 372 (br), 501a (br), 507 (gr), 550a (br), 560a (dr), 568 (br), 599 (bl), 618 (sw), 620a (bl), 628a (pr), 630a (fr), 658 (dr), 674 (bl); Jul (25x): 12 (pr), 34 (fr), 47a (sw), 71 (fr), 78 (sw), 114 (br), 188a (sw), 215a (gr), 344a (pr), 368 (dw), 448 (pr), 464 (pr), 473 (br), 507a (wr), 520a (br), 535a (br), 565a (fr), 594a (dr), 595 (hr), 596 (gr), 603 (sw), 675 (sw), 678 (pr), 724 (fr), 726 (pr); Wan (8x): 4 (hr), 28 (fr), 47 (br), 48a (hr), 77 (hr), 79a (dr), 95 (pr), 102 (hr); Prec (3x): 1 (fr), 17 (fr), 58 (br); Sea (7x): 32a (hr), 60 (hw), 63a (hw), 65a (dr), 86 (dr), 95a, 106a (dr); Vain (3x): 19 (br), 24 (br), 42 (br); Wid (5x): 14 (hw), 25a (br), 45a (hr), 68 (fr), 105 (hl); Fort (5x): 44a (fr), 55 (dr), 75 (br), 79 (dr), 82 (sn); Max I (10x): 1 (fr), 19 (fr), 39 (bl), 51 (gr), 60 (pr), $102 a$ (fr), 113 (cw), 148 (gr), 152 (wr), 159 (tr); OrW (5x): 50 (fr), 51 (fr), ${ }^{399} 65$ (br), 81 (br), 85a (fl); Rim (22x): 3 (gl), 4 (bl), 13a (scr), 28 (hl), 29 (sw), 32 (fr), 35a (bl), 38 (fr), 39 (dr), 43a (hr), 46 (br), 47 (fl), 49 (gr), 53 (bl), 55 (dr), 57 (tr), 62 (fl), 64 (wr), 66 (gr), 71 (gr), 72 (fl), 79 (hl); Pan (5x): 39a (sw), 41 (br), 46 (sw), 55 (dr), 61 (br);

${ }^{397}$ Note the clustering of four a-verse examples here (588a, 593a, 594a, 599a) in a passage of rhyme; cf. GuthB 830a, Phoen 16, Sea 95a in co-ordinate negative constructions.

${ }^{398}$ GuthA 625, 626a occur in a passage of syntactic parallelism and assonance, cf. GuthB 830a, Phoen 16.

${ }^{399}$ OrW 50-1 (fr), Ruin 3-4 (hr), Met 9.60-1a (sw), Mald 71-2 (fl) show consecutive lines of alliteration on the same cluster. 
Whale (4x): 57 (sw), 65 (sw), 81 (hw), 83a (dr); Part: 7a (sw); Soul II: 17 (dr); Rid 1-59 (53x): 1.4 (pr), 2.5 (hl), 2.13 (br), 3.4 (pr), $6 a$ (hr), 19a (fl), 24 (hl), 25a (br), 40 (br), 61 (pr), 67 (pr), 72a (sw), 4.3 (br), 6 (gr), 5.4 (fr), 6.10 (dr), 7.1 (hr), 7 (sw), 8.2 (wr), 10.2a (fl), 12.13a (sw), 15.4 (hl), $6 a$ (gr), 17.7 (sw), 10 (wl), 19.3 (sw), 20.16 (fr), 21.10 (sw), 22.8a (str), 23.12 (hr), 26.9a (br), 21 (fr), 27.11 (hr), 13 (str), 28.7 (dr), 32.4a (gr), 7 (sw), 33.3 (hl), 34.9 (bl), 35.6 (pr), 7 (hr), 37.2a (pr), 40.41 (wr), 55 (hr), 70 (sn), 94 (sw), 100 (br), 46.2 (tw), 3a (sw), 4a, 51.3 (sw), 54.4 (hr), 56.12 (fl); Wife: 33 (fr); JDay I (5x): 15 (hl), 56 (bl), 71 (br), 76 (sw), 114a (cw); ResA: 48a (fr); ResB (2x): 91 (wr), 114 (fr); Hell: 70 (dr); Husb: 19a (fr), Ruin (5x): 3-4 (hr), 14a (gr), 31 (hr), 33 (gl); Rid 61-95 (17x): 62.2 (fr), 65.1 (cw), 66.5 (gr), 74.3 (fl), 75.1 (sw), 83.1a (fr), 7 (fr), 84.3 (gr), 29 (fr), 30 (gr), 47a (hr), 52 (hr), 85.4 (pr), 86.4 (pr), 89.10 (sw), 95.4 (fr), 12 (sw); Beo (114x): 99 (dr), 102 (gr), 121a (gr), 277 (hr), 334 (gr), 351 (fr), 356 (hr), 384a (gr), 424 (gr), 454 (hr), 478a (gr), 483 (gr), 485a (dr), 527 (gr), 542 (fl), 552 (br), 555a (gr), 567a (sw), 568 (br), 583 (br), 591 (gr), 611 (hl), 641 (fr), 679 (sw), 741 (sl), 756 (dr), 765a (gr), 782 (sw), 792 (cw), 836a (gr), 892 (dr), 922 (tr), 930 (gr), 959 (fr), $1017 a$ (hr), 1027a (fr), 1104 (fr), 1111 (sw), 1120a (hl), 1126 (fr), 1148a (gr), 1189a (hr), 1195 (hr), 1207 (fr), 1231a (dr), 1246a (pr), 1282 (gr), 1286 (sw), 1306 (fr), 1319 (fr), 1417a (dr), 1470 (dr), 1487 (br), 1499a (gr), 1515 (hr), 1542a (gr), 1546a (br), 1548a (br), 1564 (hr), 1568 (fl), 1569a (sw), 1581 (sl), 1594 (bl), 1599 (br), 1624a (sw), 1691 (fr), 1707 (fr), 1775 (gr), ${ }^{400} 1940$ (cw), 2010 (hr), 2098 (sw), 2129 (hr), 2136 (gr), 2162 (br), 2179 (dr), 2264 (sw), 2328a (hr), 2353 (gr), 2357 (fr), 2386a (sw), 2398a (sl), 2402 (dr), 2406 (pr), 2448a (hr), 2476 (fr), 2503 (fr), 2504 (br), 2518 (sw), 2521 (gr), 2537 (fr), 2556 (fr), 2619 (br), 2627 (fr), 2681 (sw), 2713a (sw), 2789 (dr), 2792a (br), 2794 (fr), 2798 (sw), 2800 (fr), 2831 a (hr), 2883 (pr), 2912a (fr), 2925 (hr), 2930 (br), 2946 (sw), 2966 (sw), 2978 (br), 3002 (fr), 3041a (gr), 3053 (hr), 3062 (wr), 3117 (str), 3145 (sw); Jud (24x): 5a (fr), 23 (hl), 29 (dr), 30 (sw), 37 (hr), 55a (sn), 57 (br), 80 (sw), 83 (fr), $86 a$ (pr), 88 (sw), 106 (sw), 125 (sn), 164 (br), 199 (sn), 205 (hl), 214 (hw), 221 (fl), 240 (sw), 247 (sl), 282 (hr), 317 (br), 321 (sw), 337a (sw); PPs (93x): 58.9.1 (str), 59.1.1 (dr), 63.3.2 (sw), 64.11.4 (bl), 65.5.3 (str), 7.1 (bl), 10.1 (gr), 66.6 .2 (bl), 68.21.2 (dr), 24.3 (gr), 73.14.2 (hl), 75.5.1 (pr), 76.14.2 (str), 77.46.3 (gr), 47.3a (hr), 62.1 (sw), 63.3 (gr), 82.11.2 (hr), 84.1.1 (bl), 5.1 (wr), 85.17.2 (fr), 87.8.3 (sw), 88.11.4 (sw), 38.1 (cl), 44.2 (fr), 89.15.1a (hw), 91.11.2 (bl), 92.5.2 (hl), 93.1.1 (wr), 12.1 (dr), 13.1 (hw), 94.4.1 (dr), 100.8.4 (dr), 101.2.3 (sw), 4.5 (sw), 6.4 (sw), 18.4 (sl), 102.1.1 (bl), 19.2 (bl), 21.4 (bl), 103.1.1 (bl), 24.4 (scr), 33.4 (bl), 104.27.3 (fl), 30.2 (gr), 31.3 (fr), 34.1 (wr), 105.20.4 (gr), 106.39.3 (sw), 107.6.1 (sw), 108.5.2 (sw), 19.1 (hr), 28.3 (br), 111.5.1a (gl), 113.4.3 (sw), 21.5 (bl), 25.2 (bl), 117.14.1a (str), 16.2 (sw), 18.1 (cl), 118.12.1 (bl), 57.2 (cw), 82.3 (cw), 110.2a (wr), 119.4.1 (str), 120.4.2a (sw), 123.4.2 (hl), 6.3 (gr), 7.1 (gr), 126.5.1 (str), 6.4 (gr), 127.1.2a (dr), 128.6.1 (cw), 6.6 (bl), 129.1.2a (dr), 3.2a (dr), 133.1.1 (bl), 4.1 (bl), 134.21.4a (bl), 21.6 (bl), 135.3.2a (dr), 139.7.1a (dr), 140.4.1 (sw), 11.1 (gr), 141.5.1 (fr), 143.6.2 (hr), 7.3 (str), 8.4 (fr), 18.1 (hr), 146.10.2 (hr), 148.7.1 (dr), 149.6.3 (sw), 7.1 (wr); Met (36x): 1.3a (pr), 3.1 (gr), 2 (sw), 8 (sw), 11 (fr), 4.47a (wr), 5.8 (gr), 5.10 (hr), 40 (dr), 45 (sw), 7.16 (dr), 20a (sw), 50a (sw), 8.47a (sw), 9.56a (sw), 60 (sw), 61a (sw), 10.37 (cr), 40 (sw), 13.3a (br), 74 (hw), 20.99a (br), 104 (dr), 211 (hw), 217 (hw), ${ }^{401} 21.16$ (fr), 25.10 (sw), 13 (br), 40 (sw), 46 (sw), 26.54a (dr), 107 (sw), 28.17 (sw), 50 (sw), 29.47 (dr), 31.13 (hn); Finn (2x): 34 (hr), 35 (sw); Wald I (2x): 5a (sw), 7 (dr); Mald (15x): 9 (cn), 39 (fr), 65 (fl), 71 (fl), 72 (fl), 106 (hr), 115 (sw), 118 (sw), 137 (spr), 140 (fr), $163 a$ (br), 179 (fr), 242 (br), 295 (br), 299 (pr); Brun (4x): 30a (sw), 32 (fl), 64 (gr), 71 (br); Capt: $5 a$ (br); D Alf: 14 (bl); Dur: 1 (br); MRune (7x): 20 (wr), 24a

\footnotetext{
${ }^{400}$ Note metathesis here, and cf. PPs 77.46.3, 104.30.2.

${ }^{401}$ Met 20.211 and 217 are whole line repeats.
} 
(bl), 30a (gl), 47 (br), 66 (br), 92 (hr), 93 (bl); ${ }^{402}$ MSol (26x): I.16 (br), 34 (fr), 44 (dr), 45a (sw), 71a (cl), 89a (pr), 92 (sw), 99 (br), 114 (str), 121 (sw), 143 (sw), 144 (bl), 149a (sw), II.195 (cr), 223 (sw), 267a (sw), 291 (pr), 296 (br), 309 (sw), 366a (tw), 378a (gr), 403 (sn), 428 (tw), 430 (br), 436 (tw), 472 (bl); Men (7x): 40a (br), 58 (dr), 91 (bl), 98 (br), 104 (br), 187 (tw), 214 (cl); Max II (4x): 4 (pr), 26 (dr), 27a (fr), 34a (bl); JDay II (14x): 35 (dr), 49 (sw), 75 (hr), 105 (sw), 192 (pr), 199 (sw), 204 (cw), 217 (cw), 235 (hl), 241 (sl), 262 (hr), 277 (fr), 290 (hw), 293 (fr); Summons (2x): 2 (pr), 16 (cl); Glor I (2x): 14 (fr), 57 (cr); Creed: 44 (pr); PsFr (2x): 89.15.1a (hw), 102.1.1 (bl); KtHy (4x): 18 (dr), 20 (fr), 28 (pr), 40 (pr); KtPs: 130 (fr); Seasons (2x): 56 (br), 206 (dr); LRid (2x): 6 (br), 7 (hr); CPEp (2x): 20 (hl), 22 (dr); FrCask: 2 (gr); MCharm (10x): 1.57 (hw), 76 (bl), 79 (gr), 2.4 (br), 10a (br), 17a (wr), 4.3 (hl), 11a (fl), 6.10 (cw), 11.3a (gr), Instr: 250.

\section{1b) by cluster}

bl: GenA (4x): 14, 192, 1761, 2333; Dan: 380; And (3x): 1262, 1449, 1719; Dream: 149a; ChristC (4x): 877, 1256a, 1346a, 1391; GuthA (2x): 497, 608; GuthB: 1374a; Az: 111; Phoen (4x): 21a, 599, 620a, 674; Max I: 39; Rim (3x): 4, 35a, 53; Rid 1-59: 34.9; JDay I: 56; Beo: 1594; PPs (18x): 64.11.4, 65.7.1, 66.6.2, 84.1.1, 91.11.2, 102.1.1, 19.2, 21.4, 103.1.1, 33.4, ${ }^{403}$ 113.21.5, 25.2, 118.12.1, 128.6.6, 133.1.1, 4.1, 134.21.4a, 21.6; D Alf: 14; MRune (2x): 24a, 93; MSol (2x): I.144, II.472; Men: 91; Max II: 34a; PsFr: 102.1.1; MCharm: 1.76.

br: GenA (19x): 200, 907, 976, 1008, 1289, 1813, 1866, 2033, 2194a, 2335, 2343, 2554a, 2621, 2639, 2765, 2802a, 2892, 2929, 2932; GenB: 325a; Ex: 269a; Dan: 321; Sat: 670; And (11x): 51, 209a, 273, 504, 513, 519, 768, 1118a, 1306a, 1574, 1710; El (6x) 238a, 244, 510, 841a, 1045a, ${ }^{404}$ 1094a; ChristA (2x): 357a, 380; ${ }^{405}$ ChristC (2x): 991, 1058; GuthA (3x): 335, 654a, 804; GuthB (4x): 883, 910, 964, 1325a; Az (6x): 38, 107, 116, 142, 161, 180; Phoen (7x): 67a, 126a, 229, 283, 372, 550a, 568; Jul (3x): 114, 473, 535a; Wan: 47; Prec: 58; Vain: 19; Wid: 25a; Fort: 75; OrW (2x): 65, 81; Rim: 46; Rid 1-59 (6x): 2.13, 3.25a, 40, 4.3, 26.9a, 40.100; JDay I: 71; Beo (13x): 552, 568, 583, 1487, 1546a, 1548a, 1599, 2162, 2504, 2619, 2792, 2930, 2978; Jud (2x): 57, 317; PPs: 108.28.3; Met (2x): 13.3a, 20.99a; Mald (3x): 163a, 242, 295; Brun: 71; Capt: 5a; Dur: 1; MRune (2x): 47, 66; MSol (3x): I.16, 99, II.296; Men (3x): 40a, 98, 104; Seasons: 56; MCharm: 2.10a.

cl: El: 696; And: 1021a; Az: 137a; Phoen (2x): 226, 277a; PPs (2x): 88.38.1, 117.18.1; MSol: I.71a; Men: 214; Summons: 16.

cn: Mald: 9.

cr: Met: 10.37; MSol: II.195; Glor I: 57.

cw: El: 324; ChristA (2x): 87, 148; ChristC (2x): 891, 958; GuthA: 223; Max I: 113; JDay I: 114a; Rid 61-95: 65.1; Beo (2x): 792, 1940; PPs (3x): 118.57.2, 82.3, 128.6.1; JDay II (2x): 204, 217; MCharm: 6.10, Instr: 250.

dr: GenA (10x): 40, 81, 142, 190, 861, 1818, 2255a, 2284, 2782, 2805; GenB (3x): 257, 485, 638a; Ex (3x): 34, 79a, 547; Dan (3x): 257a, 281, 348a; Sat (9x): 44, 68, 82, 173, 186, 230, 255a, 313, 392; And (8x): 34, 73, 313, 369, 874, 1003a, 1151a, 1281; Soul I: 17; Dream (2x): 140, 144; El 81, 371a, 765; ChristA: 405a; ChristB (2x): 580a, 594a; ChristC (5x): 1108, 1274, 1408, 1508a, 1641, 1644; GuthA (12x): 14, 123a, 259, 341, 386, 464, 626a, 680, 684, 715, 727,

${ }^{402}$ MRune ll. 92-3, each with cluster alliteration, are followed by a line with strong assonance and the end of the poem, so that we have here closure with ornament.

${ }^{403}$ PPs 103.1.1 and 33.4, the first and last lines of the psalm, are whole line repeats (following the Vulgate); cf. 84.1.1, 102.1.1, 128.6.6, 133.1.1, 4.1.

${ }^{404}$ El 841a, 1045a, GuthA 335a, Phoen 126a are the same; cf. El 1094a, GuthA 654a, Phoen 550a, Jul 535a.

${ }^{405}$ ChristA 357a, 380 alliterate on the same words beginning with $b r$ - 
740; GuthB (5x): 830a, 901, 1083, 1101a, 1349a; Az (3x): 3, 64a, 102; Phoen (4x): 138, 348a, 560a, 658; Jul: 594a; Wan: 79a; Sea (3x): 65a, 86, 106a; Fort (2x): 55, 79; Rim (2x): 39, 55; Pan: 55; Whale: 83a; Soul II: 17; Rid 1-59 (2x): 6.10, 28.7; Hell: 70; Beo (10x): 99, 485a, 756, 892, 1231a, 1417a, 1470, 2179, 2402, 2789; Jud: 29; PPs (11x): 59.1.1, 68.21.2, 93.12.1, 94.4.1, 100.8.4, 127.1.2a, 129.1.2a, 3.2a, 135.3.2a, 139.7.1a, 148.7.1; Met (5x): 5.40, 7.16, 20.104, 26.54, 29.47; Wald I: 7; MSol: I.44; Men: 58; Max II: 26; JDay II: 35; KtHy: 18; Seasons: 206; CPEp: 22.

dw: GenA: 23a; Jul: 368.

fl: GenA: 1386; Sat: 111; And (2x): 1546, 1573; ChristB: 676a; GuthB: 1144; OrW: 85; Rim (3x): 47, 62, 72; Rid 1-59 (3x): 3.19a, 10.2a, 56.12; Rid 61-95: 74.3; Beo (2x): 542, 1568; Jud: 221; PPs 104.27.3; Mald (3x): 65, 71, 72; Brun: 32; MCharm: 4.11a.

fn:

fr: GenA (42x): 5, 19, 79, 132a, 884, 943, 954, 963, 968, 983, 1045a, 1072, 1108a, 1142, 1183, 1189a, 1222, 1255, 1427, 1475, 1493, 1597, 1618, 1642, 1708, 1711, 1760, 1834, 1843, 2098, 2130, 2176a, 2219a, 2332a, 2371, 2579a, 2690, 2737, 2747, 2812, 2820, 2837; Ex (4x): 38, 274a, 338, 355; Dan (6x): 35, 185, 214, 261, 303a, 465; And (8x): 556, 622, 629, 934, 1128, 1163, 1432, 1705; Fates (3x): 12a, 91, 109a; Dream: 76a; El (5x): 88, 443, 542, 1067, 1163; ChristA (3x): 207, 223, 225; ChristB (7x): 489, 507, 522, 575, 588a, 643, 839; ChristC (2x): 1290, 1340; GuthA (3x): 181, 411, 453; GuthB (4x): 820, 888, 1021, 1211; Az (2x): 24a, 97; Phoen (3x): 84, 239, 630a; Jul (4x): 34, 71, 565a, 724; Wan: 28; Prec (2x): 1, 17; Wid: 68; Fort: 44a; Max I (3x): 1, 19, 102a; OrW (2x): 50, 51; Rim (2x): 32, 38; Rid 1-59 (4x): 5.4, 20.16, 26.21, 46.4a; Wife: 33; ResA: 48a; ResB: 114; Husb: 19a; Rid 61-95 (5x): 62.2, 83.1a, 7, 84.29, 95.4; Вео (21x): 351, 641, 959, 1027a, 1104, 1126, 1207, 1306, 1319, 1691, 1707, 2357, 2476, 2503, 2537, 2556, 2627, 2794, 2800, 2912a, 3002; Jud (2x): 5a, 83; PPs (5x): 85.17.2, 88.44.2, 104.31.3, 141.5.1, 143.8.4; Met (2x): 3.11, 21.16; Mald (3x): 39, 140, 179; MSol: I.34 (fr); Max II: 27a; JDay II (2x): 277, 293; Glor I: 14; KtHy: 20; KtPs: 130.

gl: Rim: 3; Ruin: 33; PPs: 111.5.1a; MRune: 30a.

gn:

gr: GenA (6x): 46, 61, 1102a, 1137a, 1275, 2063; GenB (5x): 302, 384a, 390a, 407a, 793; Ex (2x): 312a, 330a; Dan: 438a; Sat (3x): 258a, 268a, 700a, 707a; And (7x): 217a, 254, 425a, 776a, 917a, 951a, 1590; El (2x): 759a, 834a; ChristC (4x): 970, 1003, 1204, 1526a; GuthA (2x): 375a, 571a; GuthB: 1335a; Phoen (2x): 78, 507; Jul (2x): 215a, 596; Max I (2x): 51, 148; Rim (3x): 49, 66, 71; Rid 1-59 (3x): 4.6, 15.6a, 32.4a; Ruin: 14a; Rid 61-95 (3x): 66.5, 84.3, 30; Веo (22x): 102, 121a, 334, 384a, 424, 478a, 483, 527, 555a, 591, 765a, 836a, 930, 1148a, 1282, 1499a, 1542a, 1775, 2136, 2353, 2521, 3041a; PPs (9x): 65.10.1, 68.24.3, 77.46.3, 63.3, 104.30.2, 105.20.4, 123.6.3, 7.1, 126.6.4, 140.11.1; Met (2x): 3.1, 5.8; Brun: 64; MSol: II.378a; FrCask: 2; MCharm (2x): 1.79, 11.3a.

hl: GenA (3x): 73a, 1582, 1693; Dan: 178; And (4x): 312, 739, 841a, 1360; El: 616; ChristB: 745; GuthB: 1357; Az: 85; Phoen (2x): 12, 25; Wid: 105; Rim (2x): 28, 79; Rid 1-59 (4x): 2.5, 3.24, 15.4, 33.3; JDay I: 15; Beo (2x): 611, 1120a; Jud (2x): 23, 205; PPs (3x): 73.14.2, 92.5.2, 123.4.2; JDay II: 235; CPEp: 20; MCharm: 4.3.

hn: Met: 31.13;

hr: Dan (3x): 241, 670a, 755a; ChristA: 14; ChristB: 858a; GuthA: 283; GuthB: 906a; Phoen (2x): 16, 60; Jul: 595; Wan (4x): 4, 48a, 77, 102; 406 Sea: 32a; Wid: 45a; Rim: 43; Rid 1-59 (7x): 3.6a, 7.1, 23.12, 27.11, 35.7, 40.55, 54.4; Ruin (3x): 3, 4, 31; Rid 61-95 (2x): 84.47a, 52; Beo (15x): 277, 356, 454, 1017a, 1189a, 1195, 1515, 1564, 2010, 2129, 2328a, 2448a, 2831a, 2925,

406 Note the frequency of $h r$ - alliteration in Wan (both as a proportion of $h r$ - alliteration elsewhere and of cluster alliteration in Wan) and its linking of words denoting ice and snow. 
3053; Jud (2x): 37, 282; PPs $^{407}$ (6x): 77.47.3a, 82.11.2, 108.19.1, 143.6.2, 18.1, 146.10.2; Met: 5.10; Finn: 34; Mald: 106; MRune: 92; JDay II (2x): 75, 262; LRid: 7.

hw: Sea (2x): 60, 63a; Wid: 14; Whale: 81; Jud: 214; PPs (2x): 89.15.1a, 93.13.1; Met (3x): 13.74, 20.211, 217; JDay II: 290; PsFr: 89.15.1a; MCharm: 1.57.

pr: MSol: I.89a [Latin].

scr: Rim: 13a; PPs: 103.24.4.

sl: GuthA: 343a; Beo (3x): 741, 1581, 2398a; Jud: 247; PPs: 101.18.4; JDay II: 241.

sm:

sn: And: 267; ${ }^{408}$ El (2x): 154, 313; Fort: 82; Rid 1-59: 40.70; Jud (3x): 55a, 125, 199; MSol: II.403.

spr: Mald: 137.

str: GenB: 284; Dan: 61a; And (2x): 374, 1580; Soul I: 45a; Rid 1-59 (2x): 22.8a, 27.13; Beo: 3117; PPs (7x): 58.9.1, 65.5.3, 76.14.2, 117.14.1a, 119.4.1, 126.5.1, 143.7.3; MSol: I.114.

sw: GenA (14x): 9, 134a, 938, 1081a, 1326, 1375a, 1414a, 1764, 2417a, 2543, 2559, 2659, 2672a, 2858; GenB (2x): 391a, 529; Ex: 309a; Dan (2x): 341, 528; And (4x): 72a, 1009, 1275, 1441; Dream (2x): 20a, 23a; ${ }^{409}$ El: 447; ChristC (5x): 954, 1299a, 1348a, 1411, 1530; GuthA (3x): 452, 570, 625; GuthB (4x): 1125, 1166, 1273a, 1318; Az: 59; Phoen (8x): 124, 137, 186a, 199a, 214, 315a, 317, 618; Jul (5x): 47a, 78, 188a, 603, 675; Sea: 95a; Rim: 29; Pan (2x): 39a, 46; Whale: 57, 65; Part: 7a; Rid 1-59 (10x): 3.72, 7.7, 12.13a, 17.7, 19.3, 21.10, 32.7, 40.94, 46.3a, 51.3; JDay I: 76; Rid 61-95 (3x): 75.1, 89.10, 95.12; Вeo (17x): 567a, 679, 782, 1111, 1286, 1569a, 1624a, 2098, 2264, 2386a, 2518, 2681, 2713a, 2798, 2946, 2966, 3145; Jud (7x): 30, 80, 88, 106, 240, 321, 337a; PPs (15x): 63.3.2, 77.62.1, 87.8.3, 88.11.4, 101.2.3, 4.5, 6.4, 106.39.3, 107.6.1, 108.5.2, 113.4.3, 117.16.2, 120.4.2a, 140.4.1, 149.6.3; Met (16x): 3.2, 8, 5.45, 7.20a, 50a, 8.47a, 9.56a, 60, 61a, 10.40, 25.10, 40, 46, 26.107, 28.17, 50; Finn: 35; Wald I: 5a; Mald (2x): 115, 118; Brun: 30a; MSol (8x): I.45a, 92, 121, 143, 149a, II.223, 267a, 309; JDay II (3x): 49, 105, 199.

tr: GenB: 248; Max I: 159; Rim: 57; Beo: 922.

tw: Rid 1-59: 46.2; Rid 61-95: 86.4; MSol (3x): II.366a, 428, 436; Men: 187.

pr: GenA (3x): 1217, 1308, 1492; Ex: 363; Dan (2x): 213, 424; Sat: 501; And (7x): 107, 245a, 376a, 1139, 1264, ${ }^{410}$ 1391, 1685; Fates: 18a; Dream: 84; El (15x): 123a, 151, 177, 185, 329, 483, 494, 519, 704, 858, 883, 1238a, 1276a, 1286, 1298; ChristA (2x): 288, 388; ChristB (3x): 593a, 599a, 726; ChristC (5x): 969, 1023a, 1133a, 1267, 1445a; GuthA: 646a; GuthB (3x): 1103, 1198, 1350; Phoen (5x): 68a, 144, 341a, 501a, 628a; Jul (7x): 12, 344a, 448, 464, 520a, 678, 726; Wan: 95; Vain (2x): 24, 42; Max I: 60; Pan (2x): 41, 61; ${ }^{411}$ Rid 1-59 (6x): 1.4, 3.4, 3.61, 67, 35.6, 37.2a; Rid 61-95: 85.4; Beo (3x): 1246a, 2406, 2883; Jud (2x): 86a, 164; PPs: 75.5.1; Met (2x): 1.3a, 25.13; Mald: 299; MSol (2x): II.291, 430; Max II: 4; JDay II: 192; Summons: 2; Creed: 44; KtHy (2x): 28, 40; LRid: 6; MCharm: 2.4.

pw:

wl: GenA (2x): 1825, 1848; And: 1471; Rid 1-59: 17.10.

wr: GenA (2x): 1903a, 2038a; El (3x): 387, 674, 1181a; ChristA: 416a; ChristB: 831; GuthA: 558a; Phoen: 294a; Jul: 507a; Max I: 152; Rim: 64; Rid 1-59 (2x): 8.2, 40.41; ResB: 91; Beo: 3062; PPs (5x): 84.5.1, 93.1.1, 104.34.1, 118.110.2a, 149.7.1; Met: 4.47a; MRune: 20; MCharm: 2.17a.

\footnotetext{
${ }^{407}$ But note PPs 126.3.3 with $r$ : $h r$ alliteration.

408 Or MS snude stands for sunde: see Andreas, ed. Brooks, p. 71.

${ }^{409}$ Dream 20a and 23a mark the opening and closing of a hypermetric cluster; compare the pairing of clusters in lines 140 and 144.

${ }^{410}$ 1139a and 1264a have the same phrase.

${ }^{411}$ Pan 41b and 61b are near repeats.
} 
2) cluster alliteration appears in continued alliteration (noted by line of first occurrence of the cluster)

2a: a cluster in a stressed position in one line is repeated in a stressed position of the next (or in a subsequent line of continued alliteration, with full line reference given):

GenA: 35-7 (wr), 899 (fr), 954 (fr), 1031 (dr), 2339 (hl), 2807 (sw), GenB: 688 (fr), Dan: 438 (hl), And: 336 (fr), 796 (fr), 992 (hl), Soul I: 35 (pr), El: 1141 (fr), ChristA: 368 (fr), ChristB: 512 (sw), ChristC: 939 (str), 1353 (hl), 1412-14 (hr), GuthB: 841 (bl), 1052 (hr), Phoen: 270 (br), 374 (sw), Jul: 118 (fr), 464 (pr), Soul II: 32 (pr), Rid 1-59: 8.3 (hl), 9.11 (sw), 15.27 (hr), 40.9 (sl), 77 (fl), Rid: 60.11 (sw), Rid 61-95: 62.6 (hw), 84.25 (wl), 88.20 (br), Beo: 693 (fr), 2259 (br), Jud: 300 (fr), PPs (within psalm verses): 85.13.3 (sw), 103.20.2 (gr), 106.16.2 (wr), 113.21.2 (bl), 117.23.1 (dr), (across psalm verses): 53.3.3 (gl), 68.17.3 (hr), 71.3.3 (sw), 76.2.4 (sw), 77.28.2 (sw), 85.15.4 (dr), 89.18.3 (bl), 119.5.5 (sw), 123.3.4 (sw), 126.3.4 (sw), 127.4.3 (bl), 133.3.3 (bl), Met: 10.19 (sw), Mald: 148 (dr), MSol: II.336-8 (dr), Glor I: 52 (cl).

2b: cluster alliteration at least twice in one line is augmented by appearance of the cluster once elsewhere in stressed position in the continued alliteration:

GenA: 954 (fr), 2542 (sw), And: 1448 (bl), Whale: 56 (sw), Rid 1-59: 51.2 (sw), 54.3 (hr), Rid 61-95: 95.3 (fr), Jud: 88 (sw), PPs: 84.4.3 (wr), Mald: 162 (br).

2c: cluster alliteration at least twice in one line is augmented by the appearance of the cluster more than once elsewhere in stressed position in the continued alliteration:

OrW: 50 (fr), Ruin: 3 (hr), PPs: 123.6 .3 (gr), Met: 9.60 (sw), Mald: 71 (fl).

2d: alliteration on the functional clusters sc-, sp-, st- continues for more than one line:

And: 1576 (st), ChristC: 939 (st), Rid 1-59: 2.6 (st), 16.8 (st), Jud: 78-9 (sc), PPs: 76.14 .2 (st), 103.9.2 (st), 141.1.1 (st).

3) cluster alliteration occurs in combination with enjambed alliteration (noted by first line of occurrence)

3a: a cluster in the fourth position of one line is repeated in a stressed position in the next: GenA: 934 (hl), 2315 (fr), 2670 (dr), Ex: 360 (fr), 477 (bl), 496 (sw), 500 (dr), Dan: 481 (sw), Sat: 31 (gr), 162 (dr), And: 504 (sn), 646 (bl), 1261 (br), 1402 (dr), Soul I: 104, El: 70 (sw), 239 (sw), 377 (cw), 516 (sw), 569 (fr), ChristC: 984 (fl), 1238 (bl), Az: 123 (dr), Phoen: 131 (sw), Jul: 346 (fr), Sea: 20 (hl), Vain: 15 (wr), OrW: 27 (hr), Soul II: 98 (dr), Rid 1-59: 3.56 (fl), 62 (hl), 40.29 (sw), 57.2 (sw), JDay I: 1 (fl), 94 (cw), Ruin: 1 (br), Rid 61-95: 80.3 (hw), Beo: 89 (sw), 283 (pr), 538 (sw), 1949 (fl), 2516 (hw), PPs: 56.7.1 (gr), 83.3.1 (dr), 103.1.1 (dr), 131.11.1 (sw), 146.12.1 (dr), Mald: 257 (wr), MSol: I.141 (tw), 306 (br), JDay II: 189 (gr), 213 (br), KtPs: 122 (br).

3b: a cluster in the fourth position of one line is repeated in two or more stressed positions in the next:

GenA: 1812 (br), Dan: 184 (fr), Rid: 46.1 (tw), PPs: 113.21 .4 (bl), 117.16.1 (sw), MRune: 65 (br), JDay II: 240 (sl).

4) cluster alliteration occurs in crossed alliteration (i.e. in second and fourth positions in ABAB alliteration, and in similar patterns): 
Sat: 454 (gr); El: 1178 (hw), ChristA: 424 (fr), ChristC: 1063 (br), Pan: 47 (bl), Rid 1-59: 10.6 (cw), Beo: 98 (hw), 1460 (sw), PPs: 104.27.1 (cw), 30.1 (cw), ${ }^{412}$ Met: 6.2 (cw), 8.3 (cw), 11.52 (hw), Mald: 255 (cw), MCharm: 7.8 (wr).

[See Appendix Five for crossed alliteration with sc-, sp- st-.]

5) cluster alliteration occurs in the fourth position together with at least one other position of the line in patterns other than crossed alliteration

5a) in defective or postponed alliteration:

AB CA: GenA: 2046 (tr),

AB CB: Met: 11.57 (gr)

5b) in transverse alliteration:

AB BA: ?Mald: $189(\mathrm{hl})$

5c) with double alliteration in the b-verse (mainly doubtful)

AB AA: Met: $19.23(\mathrm{hw})$

AA AA: ?Beo 1151 (hr), ?Rim 71 (gr), ?Soul II 103 (hl)

\section{Appendix Two: Continued Alliteration}

Alliteration over two lines is denoted only by the first line of occurrence; longer continuations have full line references and are given in bold. (?) after a line reference means that the lines are presented differently in edition(s) other than ASPR and without the alliteration continued. In bold square brackets after the line reference, participation of that line in enjambed alliteration [enj] with the preceding line, or of either line of continued alliteration (or of any line in longer continuations) in crossed alliteration [cr] is noted. In round brackets is indicated the alliterating sound where that sound occurs in less than $6 \%$ of the alliterations in the poetry (as listed in Table One].

\section{A: Consonant Alliteration}

By text:

In round brackets after the line reference the alliterating consonant is indicated where that sound occurs in less than $6 \%$ of the alliterations in the poetry (as listed in Table One).

GenA (57x): 35-7, 50 [enj], 52, 110, 191 (b), 854 (n), 899 [enj], 905 [enj], 919, 935 [enj], 940, 954, 1014-16 [cr], 1031 (d), 1079, 1138, 1172, 1183, 1284 (n), 1411, 1448, 1506, 1568, 1588, 1609, 1631, 1672, 1695 [cr], 1799 (b), 1803, 1847 [enj], 1956, 1991, 1999, 2013, 2017, 2139, 2162, 2180, 2220, 2339, 2344, 2419, 2475, 2505, 2542, 2559, 2574, 2580, 2586, 2602 [cr], 2641, 2682 [enj], 2697 [enj, cr], 2714, 2803, 2807-9 [cr]; GenB (11x): 300, 303 [cr], 352, 466, 508 (l), 688, 741, 775, 780, 796 (cf. VG 6-7), 824 [enj]; Ex (8x): 101, 112 (sc), 119, 298, 438, 442, 553, 574; Dan (14x): 11, 96, 175 [cr], 207 (?), 211, 217, 239, 260, 392, 420, 438, 441, 445, 705 (c); Sat (18x): 83, 124, 131, 192, 194 (b), 222, 305, 323, 331, 374 [enj], 420, 434, 524-6, 544, 604 (d), 607, 693, 705; And (39x): 39, 70, 91, 129 (c), 197, 212 [enj], 306, 336, 372, 392, 403 (l), 589-91, 651, 726, 796, 814, 904, 919 [enj], 964 [cr], 992, 1027 (b), 1031, 1070, 1197, 1214, 1252, 1257, 1315, 1363 (l) [cr], 1365, 1408, 1423 (l) [enj], 1430, 1448 (b), 1527, 1553, 1576 (st), 1629 [cr], 1706 (l); Fates (4x): 1, 46, 114, 116 (b); Soul I (3x): 31 [enj], 35 (p), 82-4; Dream (3x): 14, 25 [enj], 141; El (36x): 15, 91 (b), 148, 230, 294 [enj], 302 (d), 446, 539 (p), 543, 575 (l), 581-3(?), 628, 636, 670, 740 [enj], 742, 826, 851, 857 (b),

${ }^{412}$ PPs 104.27.1 and 30.1 are near verbatim repeats. 
898 (l), 925, 937, 939, 977, 996, 1070, 1078, 1095, 1120, 1125 (b), 1141, 1158 (d), 1175, 1208 (l) [enj], 1214, 1308; ChristA (16x): 2, 9, 93, 128, 154, 160, 213, 220, 229 [enj, cr], 265, 318, 320, 368, 375, 428 (d); ChristB (14x): 445, 475, 512, 528, 572, 586, 680, 692, 749, 776 (l), 816, 820 [cr], 848, 858; ChristC (29x): 868, 872, 899, 939 (st), 987, 1007, 1017, 1034, 1081, 1118 (l), 1163, 1177, 1205 (d) [enj], 1222 (c), 1248, 1306, 1353, 1387, 1403, 1412-14, 14313, 1439, 1443, 1454, 1469 (l), 1479, 1487, 1523, 1534; GuthA (13x): 65, 138 (l), 232, 322, 363 (l), 423 (l), 567, 616, 622, 665, 768 (l), 780 [cr], 811; GuthB (14x): 831 (l), 845, 848, 941 (b), 960, 965, 1052, 1095 (r), 1170 (l), 1207, 1220, 1307 (l), 1323, 1363-5; Az: 157; Phoen (23x): 18, 91, 140-2, 161, 170, 181, 208, 218, 270 (b), 283 (b), 304, 331, 342 [enj], 362, 374 [cr], 446, 461 [cr], 465 [enj], 471, 474, 476, 569, 611; Jul (37x): 46, 59, 118, 143, 152, 167-9, 215, 229, 289 (c), 320, 341, 348, 355, 361, 377 (l), 397, 408 (l), 428, 454 [enj], 464-6 (b), 494, 507, 515, 522, 564, 569, 575, 620, 631, 640, 652 (l), 664 [enj], 668, 675, 681, 694 (b), 709; Wan (3x): 36, 48, 64; Gifts (2x): 43, 78 (p); Prec: 31; Sea (5x): 1, 15, 17, 63, 85; Vain: 47; Wid (6x): 33, 77, 84, 100, 118, 129; Fort (2x): 26, 52; Max I (4x): 68, 101, 123, 203; OrW (5x): 11, 26 [enj], 36, 50, 75; Rim: 24; Pan: 34; Whale (4x): 24, 32, 56, 70; Part: 7; Soul II (2x): 28 [enj], 32 (b); Deor: 28; Wulf: 12; Rid 1-59 (28x): 2.6 (st), 3.5, 5.7, 7.3, 8.3, 9.11 [cr], 14.10, 15.27, 16.5, 8 (st), 20.4, 22, 32, 21.4, 22.17 (b), 31.4, 7-9 [cr], 18, 36.1, 40.9, 47-9, 54, 75 (l), 77, 43.11 (b), 47.2 [cr], 51.2, 54.3; Wife: 25; JDay I: 108 [enj]; ResB (3x): 101, 104, 113; Hell (4x): 27, 61 (b), 93, 109; Pha: 2; LPr I: 4 (r) [cr]; HomFr II: 9; Rid 60:11; Husb: 33; Ruin: 3; Rid 61-95 (14x): 61.4, 62.6, 65.5 [cr], 68.1, 73.26 [enj], 28, 83.11, 84.25, 41, 88.20 (b), 91.4, 93.21, 29, 95.3; Вео (49x): 63, 216, 370, 396 [cr], 403, 489, 606, 644 [enj], 693, 799, 808, 865, 871, 897-9, 915, 919, 936, 969 [enj], 1083, 1205, 1239 (b), 1346, 1368, 1520, 1552, 1622 (l), 1632 [enj], 1699, 1715, 1824 (cr), 2011, 2032 (b), 2043, 2137, 2171 [enj], 2176 (b), 2201, 2259 (b) [enj], 2285, 2336, 2344, 2362, 2382, 2553, 2601, 2859, 2863 [enj], 2987 [cr], 3004 [enj]; Jud (16x): 17 (b), 57 (b) [cr], 78 (sc) [cr], 88, 116, 124, 130, 141, 148, 160, 164 (b) [cr], 174 (b), 194, 206, 220, 300; PPs (133x, not continued across psalm verses): 54.2.2, 56.4.2, 9.1, 58.6.2, 14.2, 59.5.2 [enj], 60.1.5, 61.8.1, 62.8.3, 64.12.2, 13.1, 67.2.2, 4.3, 18.2, 68.16.2, 32.1, 69.5.2, 70.3.2, 21.2, 71.12.2, 17.3, 72.4.1, 11.3, 19.2, 21.1, 22.2, 73.4.2, 74.6.2, 75.2.1, 76.14 .2 (st) [enj], 77.12.2, 18.1, 44.1, 59.1, 71.1, 78.14.3, 79.9.1, 12.1, 80.12.1 (l), 82.2.1, 84.5.2 (c), 85.2.1, 13.3, 86.3.1, 4.1, 87.1.1 (d), 5.1, 13.2, 88.12.1, 23.1, 27.2, 41.1, 90.12.1, 91.2.1, 6.4-6, 93.17.2, 18.1, 18.3 [enj], 19.2, 94.3.1, 9.4 (c), 95.5.1, 98.10.1, 99.2.2, 101.14.2, 18.2, 21.4, 23.2-4 [enj], 102.10.1, 14.1, 18.1, 103.9.2 (st) [enj], 20.2, 29.1, 104.7.1 (d), 8.1, 105.7.4, 9.2-4, 10.2-4, 12.2 [enj], 24.1, 106.16.2, 20.2, 30.2, 107.6.2 [enj], 108.5.1, 15.1 (d), 21.2, 24.2, 25.2, 110.3.1, 4.1, 112.4.2, 113.9.1 (n), 21.2 (b), 23.2, 114.8.5 (l), 117.7.1, 23.1 (d), 118.3.1, 5.1, 14.1-3, 33.2, 42.2, 54.1, 55.1 (n), 65.2, 88.1, 101.2, 142.1, 146.2, 147.3, 168.2, 119.6.1, 121.4.1 (c), 123.3.2, 128.4.1, 131.1.1 [cr], 134.9.2, 136.4.2 [enj], 138.3.3, 18.1-3 [cr], 139.10.1, 140.6.1, 141.1.1 (st), 143.6.1, 144.5.3, 9.2, 12.2, 146.5.1, 7.1, 147.5.2, 148.9.1, (101x, continued across psalm verses): 53.3.3, 55.1.3, 3.2, 7.3, 8.4-9.2, 62.7.4, 63.4.4, 5.3, 67.24.6 (b), 68.11.3, 14.4-15.2, 17.3, 28.3, 30.2 (l), 34.2, 69.4.2, 6.2, 71.3.3, 72.1.4, 6.5, 18.2, 73.9.4, 13.3 (d), 75.6.5, 76.2.4, 77.5.3, 19.3, 21.2, 22.2, 28.2, 35.2, 51.3, 64.2, 69.3, 79.16.4, 83.11.3, 84.4.3, 6.2, 85.7.3-8.2, 15.4 (d), 16.3-17.2, 88.26.3, 36.2-37-2, 89.14.3, 18.3 (b), 92.5.3, 93.13.4 (r), 15.3-16.2, 98.7.3, 100.3.3, 101.17.2-18.1, 18.4, 103.3.2, 5.2, 104.3.3, 24.2, 34.3, 105.25.6, 106.10.3, 40.3, 112.1.2 (n), 113.21.7, 118.17.3, 25.2, 26.4, 62.4 (d), 89.2, 103.4 (b), 111.4, 114.3, 125.2, 141.3, 151.1-2.1, 119.5.5-6-2, 120.1.2, 3.2, 5.3, 121.2.3, 122.3.5-4.2 [cr], 123.3.4, 6.3, 124.3.3, 125.1.4, 126.1.3, 3.4, 127.2.3-3.2, 4.3 (b), 128.4.4, 133.3.3 (b), 135.7.2-9.1, 139.8.5-9.1, 141.1.3 (b), 142.5.4, 10.4, 144.4.3, 6.3, 12.4 (r), 19.6, 145.4.3, 146.11.3, 148.13.4; Met (40x): 6.7, 8.2 [cr], 9.43 (n), 60, 10.19, 11.16, 30, 42, 89, 93, 97, 12.9 [enj], 29, 13.31, 17.6, 19.43, 20.21, 49, 74, 80 [enj], 96, 101, 153, 203 [enj], 221 [enj], 272, 21.31, 22.37, 24.1, 34, 43, 25.54, 69, 26.59 (c), 111, 28.80, 29.76 [enj], 80, 30.17, 31.10; Finn: 38 [cr]; Mald (13x): 21, 29 [enj], 71, 81, 95-7 [enj], 110 (b), 148 (d), 162 (b), 199, 259, 276 
(b), 290 (b), 302; Brun (2x): 36, 54 (d); DEdg: 33; Dur: 6; MSol (16x): I. 82, 90, 135, 145, 157, 170, 172, II.182, 194 (c), 197 (p), 280, 336-8 (d), 368 (l), 434, 469, 502; Men (3x): 100, 159, 201; JDay II (5x): 7 [enj], 14 (d), 24, 50-2, 294; Summons: 18 (c); LPr II (2x): 72, 83; Glor I (2x): 50, 52 (c); LPr III: 2; Creed: 39; PsFr (3x): 24.6.4, 50.1.1, 87.13.2; KtPs (6x): 34, 53, 66, 75, 104, 119; Pr: 29; Thureth: 8 [enj]; Seasons (5x): 8 (l), 155, 186, 208, 224; ; CPEp (2x): 8, 13; GDPref : 17; MCharm (6x): 2.14-16 (st), 17-18, 45-6, 5.4, 7.8-9, 8.11-12; Instr (5x): 6, 68, 163, 203, 249 (c).

By consonant where that sound occurs in less than $6 \%$ of the alliterations in the poetry in descending order of frequency (as listed in Table One) [e.gs in PPs within psalm verses precede those across verses]

b: GenA: 1799, Sat: 194, And: 1027, 1448, Fates: 116, El: 91, 1125, GuthB: 941, Phoen: 270, 283, Rid: 22.17, 43.11, 88.20, Beo: 1239, 2176, 2259, Jud: 17, 57, 174, PPs: 113.21.2, 67.24.6, 89.18.3, 118.103.4, 127.4.3, 133.3.3, 141.1.3, Mald: 110, 162, 276, 290

I: GenB: 508, And: 403, 1363, 1423, 1706, El: 575, 898, 1208, ChristB: 776, ChristC: 1118, 1469, GuthA: 138, 363, 423, 768, GuthB: 831, 1170, 1307, Jul: 377, 408, 652, Rid 1-59: 40.75, Beo: 1622, PPs: 80.12.1, 114.8.5, 68.30.2, MSol: II.368, Seasons: 8

d: GenA: 1031, Sat: 604, El: 302, 1158, ChristA: 428, ChristC: 1205, PPs: 87.1.1, 104.7.1, 108.15.1, 117.23.1, 73.13.3, 85.15.4, 118.62.4, Mald: 148, Brun: 54, MSol: II.336-8, JDay II: 14

c: And: 129, ChristC: 1222, Jul: 289, PPs: 84.5.2, 94.9.4, 121.4.1, Met: 26.59, MSol: II.194, Summons: 18, Glor I: 52, Instr: 249

p: Soul I: 35, El: 539, 857, Jul: 464-6, 694, Gifts: 78, Soul II: 32, Beo: 2032, Jud: 164

r: GuthB: 1095, LPr I: 4, PPs: 93.13.4, 144.12.4

n: GenA: 854, 1284, PPs: 113.9.1, 118.55.1, 112.1.2, Met: 9.43, MCharm 2.45-6

t:

st: And: 1576, ChristC: 939, Rid 1-59: 2.6, 16.8, PPs: 76.14.2, 103.9.2, 141.1.1, MCharm 2.1416

sc: Ex: 112, Jud: 78

sp:

p: MSol: II.197

\section{B: Vowel Alliteration}

GenA (48x): 6 [enj], 29, 185, 871, 952, 972, 1005, 1022, 1054, 1076, 1104, 1117 [cr], 1208, 1338, 1402, 1508, 1645-9, 1715, 1767, 1844, 1870, 1873-5, 1959, 1993, 2020, 2136, 2164, 2177 [enj], 2184, 2208, 2224 [enj], 2238, 2288, 2394, 2398, 2445-7, 2489, 2513, 2576 [enj], 2637, 2643, 2677, 2702, 2751, 2767, 2788, 2911, 2930; GenB (7x): 292, 337, 356, 398, 539, 790, 820; Ex (5x): 186, 303, 358, 411-13 [cr], 579; Dan (7x): 106, 133, 186 [enj], 242, 271-4 [enj], 396, 756; Sat (23x): 20, 50, 60 [enj], 73-5, 94, 106 [cr], 112, 115-17, 166, 169, 202, 226, 243, 252, 302, 321, 372, 377, 388, 408, 440, 688 [cr], 701; And (21x): 15, 53, 188, 202, 25860, 277, 298, 326, 400, 492, 703, 779, 792, 910, 1057, 1104, 1174, 1223 [cr], 1351, 1375 [enj], 1712 [enj]; Fates (3x): 16, 23, 84; Soul I: 120; El (15x): 255, 300, 349, 396, 404 [enj], 435, 
472 [enj], 512, 571-3, 590, 619, 712-14, 1001, 1100, 1196; ChristA (4x): 132, 237, 332 [enj], 350; ChristB (4x): 614, 620, 626, 823; ChristC (18x): 879 [cr], 922, 1004, 1051, 1099, 1155, 1194, 1292, 1302, 1315-17, 1323, 1331, 1336, 1396, 1490, 1496, 1501, 1576-8 [enj, cr]; GuthA (4x): 355, 525, 555, 782; GuthB (7x): 852, 1064, 1078, 1118, 1277, 1296, 1319; Az: 152; Phoen (6x): 43, 93, 177, 230, 365, 392; Jul (9x): 104, 115-17, 307, 352, 403, 562 [cr], 626 [enj], 633, 701; Wan: 84; Prec: 36; Sea: 24; Vain (2x): 67, 74; Wid (4x): 37 [enj], 40, 82, 86-8; Fort (2x): 59, 96; Max I: 135; Pan (2x): 17 [enj], 73 [enj]; Soul II (3x): 13, 100, 115; Rid 1-59 (3x): 3.33, 43.4, 46.5-7 [enj]; Wife (2x): 28, 35; ResA: 69; Rid 60: 5; Rid 61-95 (2x): 93. 16, 26, Beo (13x): 70, 111, 357, 830, 906 [cr], 1328, 1458, 1620, 1762, 1865, 1885, 2534 [enj], 2866; Jud (6x): 64, 75, 108, 169, 217, 231; PPs (91x, not continued across psalm verses) : 53.7 .2 [enj], 54.3.1, 22.2, 56.8.2, 57.4.1, 64.8.1, 65.6.2-4, 66.6.3, 67.7.3, 68.9.2 [enj], 20.2, 27.1, 70.3.4, 19.3, 71.10.2-4 [enj], 73.1.1-4, 17.2, 20.2-4, 74.4.1, 75.4.2, 5.4, 76.5.1, 77.40.2, 45.2, 58.1, 79.15.2, 82.6.2, 9.3, 14.1, 84.3.1, 86.6.1, 87.7.1, 89.6.2, 11.2, 93.9.1-3 [cr], 12.2 [enj], 94.2.1, 95.4.2, 100.7.2, 102.2.2, 9.1, 103.11.1 [cr], 25.4, 28.2, 30.1, 104.9.1, 31.1, 105.6.2 [enj], 29.2, 32.1, 35.2, 106.24.2, 34.2, 108.13.1, 110.4.5, 113.1.1, 7.1, 10.3, 14.1, 117.4.1, 118.18.1, 51.1-3, 61.2, 84.1, 99.1, 104.2 [enj], 107.1, 128.1, 136.3, 142.3, 148.1, 161.1, 163.1-3, 119.3.1, 122.2.1, 5.3, 123.1.2, 124.1.3, 5.2, 129.4.2, 6.2, 8.1, 134.8.3, 12.1, 20.1, 136.7.4, 138.12.1, 15.2, 139.11.3, 143.15.2, 148.11.3, (79x, continued across psalm verses): 51.6.4, 52.4.4-5.2, 55.4.6, 58.5.5, 13.3, 59.1.3, 64.4.3, 7.3-8.2, 66.5.2, 67.8.3, 68.7.5-8.1, 22.2, 25.2-26.2, 35.3-36.2, 69.3.2, 70.18.4, 71.6.3, 15.4, 19.5, 72.17.4, 73.18.4, 77.13.3, 30.4, 45.2-46.1, 79.7.2, 80.8.2, 81.5.36.2, 82.4.4, 82.8.5, 85.4.3, 86.5.3, 88.16.1-17.1, 20.2, 44.3, 89.8.4, 91.8.4, 9.3, 93.1.2, 5.2, 10.2, 95.12.6, 97.8.4-9.1, 100.4.5, 102.18.3, 104.17.2, 19.3, 32.4, 105.14.3, 106.15.1-16.1, 27.2, 107.2.4, 108.3.3, 27.4, 111.7.4, 112.5.3-6.1, 113.17.2, 118.5.3-7.1, 20.3, 38.3-39.2, 55.3, 57.3, 77.4-78.2, 85.3-86.2, 91.4, 92.4, 118.3-119.2, 152.3, 129.2.3, 132.1.3, 135.10.1-11.2, 20.2, 22.1-24.1, 136.8.2-9.2, ${ }^{413}$ 138.2.5-3.2, 140.8.5, 144.9.4, 15.2, 147.8.3; Met (79x): 1.39, 57, 62 [enj], 4.35-7, 5.11, 27, 32, 7.8, 28, 42-5, 8.5, 18, 9.47 [cr], 51, 10.8, 17, 11.4-10, ${ }^{414} 21,68,85$, 12.17, 31, 13.62-4, 70-3, 76-80 [cr], 14.4, 16.3 [enj], 16-20, 17.15-17, 23, 28, 18.6, 20.12-14, 19, 32-4 [enj], 38, 41, 55, 64, 106 [enj], 132, 137, 141-5 [enj], 155, 166, 184-6, 219, 224, 233, 21.13-15, 22.9 [enj], 14, 17, 20, 54, 24.19, 23, 49, 57-9, 62 [enj], 25.33, 56-60, 62, 26.50, 94, 116-18 [enj], 27.13, 21-3, 28.12, 29, 57 [enj], 70, 75, 29.10, 18-20, 32-4, 43-5, 30.12, 15 [cr]; Mald (7x): 5, 51-3, 69, 132, 206, 230 [enj], 233; Brun: 69; CEdg: 3; DEd: 1; Dur: 12-14; MRune: 76; MSol (5x): I.28, II.233 [enj], 376, 474-6, 497; JDay II (8x): 37, 93, 142, 145 [cr], 163-5, 225, 228, 304; Exhort (2x): 22, 77-9; LPr II (2x): 112, 118; Creed: 3; KtHy: 37; KtPs (2x): 60 [cr], 128; $\operatorname{Pr}(3 \mathrm{x}): 15$, 34, 59; Aldhelm (2x): 3 [enj], 9-11; Cced: 4; MEp: 7; MCharm (2x): 2.54-5, 4.17-18; Instr (8x): 33 [cr], 42, 45, 48 [enj], 80, 86-8, 114, 181-4 [enj], 231.

Totals: $\quad$ Continued consonant alliteration: 850 instances (1732 lines)

Continued vowel alliteration: 526 instances (1144 lines)

Overall total: 1376 instances (2876 lines)

${ }^{413}$ Six consecutive lines.

${ }^{414}$ Seven consecutive lines. 


\section{Appendix Three: Interlaced Alliteration}

The alliterating sounds are given in round brackets after the line reference (where $\mathrm{v}$ stands for vowel alliteration). In italics are instances with at least one stressed word (either as a separate lexeme or as the first element of a compound) repeated in the interlaced section. In bold are passages which exactly correspond with the opening or closing of a speech. Following in bold in square brackets are instances in the interlaced passages of cluster [cl], enjambed [enj], or crossed $[\mathbf{c r}]$ alliteration together with a line reference for that extra alliteration.

a) with four lines of verse interlaced in the pattern abab (a total of 88 examples):

GenA (6x): 1689-92 (w,v,w,v), 1823-6 (w,v,w,v) [1825: cl], 1926-9 (s,v,s,v) [1927: enj], 20025 (v,w,v,w) [2003: cr, 2004: enj], 2698-701 (f,w,f,w) [2698, 2701: cr], 2887-90 (w,f,w,f); GenB: 313-16 (v,f,v,f) [314: enj]; Dan (3x): 128-31 (d,s,d,s), 187-90 (v,p,v,p), 430-3 (c,h,c,h); Sat (3x): 108-11 (d,f,d,f) [111: cr], 275-8 (h,v,h,v), 647-50 (g,w,g,w); And (5x): 36-9 (h,m,h,m) [38: cr], 73-6 (d,v,d,v) [72a: cl ], 261-4 (w,m,w,m), 675-8 (w,v,w,v), 1128-31 (f,v,f,v) [1128: cl, 1129: enj]; Dream: 15-18 (w,g,w,g); El: 1199-1202 (s,g,s,g); GuthA (2x): 568-71 (s,g,s,g) [570, 571a: cl], 593-6 (l,w,l,w) [593: enj]; Phoen (5x): 3-6 (f,m,f,m) [4: enj], 54-7 (s,w,s,w) [54: enj], 284-7 (b,v,b,v) [286: enj], 308-11 (sc,f,sc,f), 526-9 (v,w,v,w); Jul (2x): 247-50 (d,w,d,w), 579-82 (b,v,b,v); Wan: 5-8 (w,v,w,v); Prec: 51-4 (f,s,f,s) [53: cr], Rid 1-59 (3x): 19.1-4 (s,h,s,h) [3: cl], 39.2-5 (m,s,m,s), 40.101-4 (sc,w,sc,w); Wife: $14-17$ (l,h,l,h); Beo (13x): 373-6 (v,h,v,h) [373: enj, 374: cr], $454-7$ (h,w,h,w), 671-4 (v,h,v,h), 1000-3 (v,f,v,f), 1068-71 (f,h,f,h), 1292-5 (v,f,v,f), 1311-14 (s,v,s,v) [1311, 1314: cr, 1311: enj], 1349-52 (v,w,v,w) [1349: enj], 1499-1502 (g,v,g,v) [1499a: cl], 1546-9 (b,v,b,v) [1546a, 1548a: cl], 1738-41 (v,w,v,w) [1738: enj], 2193-6 (s,b,s,b), 3123-6 (v,h,v,h) [3123: enj]; PPs (23x): 62.9.1-4 (v,s,v,s) [9.1: enj], 70.7.3-8.2 (w,v,w,v) [8.1: enj], 72.19.3-21.1 (w,h,w,h), 75.8.2-9.1 (g,v,g,v), 76.8.1-4 (v,m,v,m), 77.30.1-4 (m,v,m,v), 78.1.3-2.3 (v,s,v,s) [2.1: enj], 79.8.1-9.1 (v,w,v,w), 88.6.3-7.2 (m,v,m,v), 8.1-9.1 (w,v,w,v), 9.2-10.2 (h,v,h,v), 24.1-25.2 (f,v,f,v), 93.16.3-17.2 (m,f,m,f), 101.16.3-17.2 (f,h,f,h), 102.1.1-2.2 (b,v,b,v) [1.1: cl], 105.11.3-12.1 (v,w,v,w), 106.14.1-15.1 (m,v,m,v), 110.2.2-3.1 (s,m,s,m), 112.4.3-5.3 (h,v,h,v), 113.21.3-6 (b,v,b,v) 
[21.3, 21.4: enj, 21.5: cl], 128.1.1-4 (f,v,f,v), ${ }^{415} 138.16 .1-4$ (r,s,r,s), 144.5.4-6.3 (w,m,w,m) [5.4: enj]; Met (10x): 5.33-6 (v,w,v,w), 10.58-61 (v,h,v,h), 11.37-40 (v,f,v,f), 17.3-6 (v,w,v,w) [17.4: enj], 20.61-4 (f,v,f,v), 216-19 (sc,h,sc,h) [217: cl], 259-62 (v,s,v,s), 25.39-42 (w,s,w,s) [25.40: cl, enj], 28.58-61 (v,w,v,w) [28.58: enj], 30.9-12 (sc,v,sc,v) [30.10: enj]; MSol (4x): I.32-5 (f,v,f,v) [I.34: cl, enj], 63-6 (g,s,g,s) [65: enj], II.205-8 (c,g,c,g), 444-7 (w,f,w,f); JDay II: 280-3 (v,h,v,h); KtPs: 84-7 (m,v,m,v); GDPref: 24-7 (s,v,s,v).

b) with five lines of verse interlaced in the pattern ababa (a total of 18 examples):

Sat: 141-5 (v,s,v,s,v); And: 441-5 (v,b,v,b,v); El: 287-91 (w,g,w,g,w); ChristB (2x): 682-6 (g,v,g,v,g), 745-9 (h,m,h,m,h) [745: cl]; GuthA: 296-300 (w,v,w,v,w); Phoen: 401-5 (v,b,v,b,v); Max I: 143-7 (f,w,f,w,f) [144: cr, 145, 146: enj]; Beo (2x): 1097-1101 (v,w,v,w,v), 1660-4 (w,v,w,v,w) [1661, 1663: enj]; PPs (3x): 120.6.4-7.3 (v,s,v,s,v), 131.12.4-13.3 (s,w,s,w,s), 150.1.1-3.1 (h,m,h,m,h) [1.2, 2.1: enj]; Met (4x): 5.28-32 (v,w,v,w,v), 7.38-42 (v,w,v,w,v) [7.38: enj, 7.40 cr], 8.37-41 (w,v,w,v,w), 22.5-9 (v,s,v,s,v) [22.7, 22.8: enj]; MSol: II.282-6 (w,st,w,st,w).

c) longer passages with this type of interlace:

Rid 1-59: 40.81-90 (w,v,w,v,w,v,w,v,w,v) [84, 89: enj]; Beo: 3153-8 (h,w,h,w,h,w) [3153: cr].

d) with seven or more lines of alternating vowel and consonant alliteration:

GenA 1517-23 (7 ll.) [1521, 1522: enj]; Sat: 389-95 (7 ll.) [389: enj, 392: cl]; Met (4x): 4.2935 (7 ll.) [4.33: enj], 9.20-8 (9 ll.) [9.20: enj], 16.4-13 (10 ll.) [16.6: enj, 16.8: cr], 20.117-32 (16 ll.) [20.123: cr, enj]; Pr: 48-57 (10 ll.) [54: enj].

${ }^{415}$ PPs 128.1 .1 and 1.3 are whole-line repeats. 


\section{Appendix Four: Enjambed Alliteration}

Line references are to the line in which the final stress alliterates with the following line. A question mark in brackets after the line reference indicates that editions disagree materially upon the point. In bold square brackets after the line reference, participation of that line in crossed alliteration [cr] is noted. In round brackets is indicated the alliterating sound where that sound occurs in less than $6 \%$ of the alliterations in the poetry (as listed in Table One]. Consecutive lines of enjambed alliteration are indicated in bold.

GenA (154x): 1, 5 [cr], 71, 75 (p), 94, 96, 100 [cr], 109, 118, 136 (sc), 137, 156, 160, 167, 198, 200, 209, 210 (l), 852, 867 (l), 888 (n), 904, 934, 944 (l), 957, 968 (c), 990 [cr], 1023-4, 1042, 1073, 1089, 1096, 1111, 1133, 1144-5 (l), 1149, 1162 [cr], 1179 (l), 1186, 1190, 1194-5 (l), 1243, 1253, 1261, 1265, 1296 (c), 1298 [cr], 1300, 1314, 1339, 1345, 1351, 1364, 1375 (st), 1385, 1409 (l), 1445 [cr], 1456 [cr], 1476, 1479, 1513, 1521-2, 1533, 1558, 1562, 1573, 1576, 1581, 1598, 1602 (b), 1618 (c)-19, 1629, 1637, 1641, 1659, 1668, 1670 (l), 1707, 1716, 1727, 1730, 1733, 1769-70, 1784, 1788, 1812 (b), 1821 (b), 1839, 1846 [cr], 1853, 1902, 1925 [cr], 1927, 1964 (b), 1966, 2004, 2030 (r)-1, 2039, 2071, 2081 (d), 2129, 2140, 2149, 2176, 2191 (r), 2212 (b), 2223, 2232, 2243, 2245, 2259, 2267, 2270, 2272, 2274, 2282 [cr], 2315, 2320, 2324 (d), 2373, 2375, 2421, 2447, 2501, 2506, 2531, 2546, 2548 (c) [cr], 2551, 2555, 2565, 2600, 2621, 2623, 2670 (d), 2675, 2681, 2696, 2703-4 [cr], 2709, 2763, 2809, 2857-8, 2879 [cr], 2931 (b); GenB (46x): 249, 254, 258-9, 269, 277 [cr], 309, 328, 332 (l)-3, 369, 384, 390, 408 (b), 429 (b)-30, 434 (l), 443, 474, 478 (b), 484 (d), 490, 504, 529, 540 (t), 559, 581-2 [cr], 587 (l), 623 (l), 634, 640 (b)-1, 653, 658, 666, 671, 678, 708, 711, 744, 748, 758, 761, 785, 805, 818, 823, 836; Ex (42x): 5 (l), 7, 40 (d) -1, 43 (l), 47-8, 52 (l), 68, 73, 102, 121, 131 (b), 138, 194 (l), 229 (c), 256, 266, 275, 279, 282, 286, 295 (r), 306-7 (l), 330, 333, 360, 368, 383 (l), 401, 420 (c), 466, 473, 477 (b), 479, 486 (?), ${ }^{416}$ 496, 500 (d), 549, 565, 584; Dan (42x): 16,

${ }^{416}$ For discussion of the problem here, see F. Robinson, The Editing of Old English (Oxford, 1994), pp. 100-2. 
21 (d), 28 (l), 36 (d), 43, 84, 102, 110, 115, 124, 136, 144, 168, 184-5, 214 [cr], 270, 276, 301 (l)-2, 328, 363, 369, 406, 434 (l), 451 (l), 458, 476 (d), 481, 511, 514, 523, 536, 563, 597, 600, 629, 692 (b), 698 (b), 701, 730-1; Sat (53x): 16, 31, 59, 87, 117, 119, 121, 137 (b), 162 (d), 173, 177, 209, 218 [cr], 234, 263-6, 290 (l), 298 (l), 336, 338, 340-1, 343, 346-7, 349, 360, 373, 389, 413, 424, 474, 480, 482, 502, 526, 541, 547-8, 566-7 (p), 571, 593, 637-8, 643, 645, 695 [cr], 707 (t), 713 (l), 722; And (110x): 9, 17, 21, 23, 31 [cr], 41, 58, 64, 78, 97, 133 (r), 155, 183 (b), 209, 211, 245, 286, 299, 355, 361, 410, 480, 504, 506, 516, 528, 530, 538, 551, 553, 563, 568 [cr], 577, 579-80 (b), 646 (b), 690, 713, 719, 722, 737 (st), 758, 781, 808, 827 (c), 833 (n), 854 [cr], 867 (l), 874, 918, 928 (c), 941, 967, 975, 987, 996 (b)-7, 1018, 1052-3, 1055, 1064 (b), 1073, 1129, 1133-5 (b), 1151, 1158, 1171, 1187, 1218, 1241, 1261 (b), 1312, 1330, 1335 (st), 1339, 1374, 1386, 1394, 1402 (d), 1404 (b), 1410 (c), 1415, 1417, 1422 (l), 1451, 1455, 1466, 1470, 1474 (d), 1478 (l)-9, 1501, 1529, 1532 (b), 1567, 1572, 1578, 1606, 1630 [cr], 1658, 1660, 1677, 1685, 1695 (d), 1700, 1721; Fates (4x): 47, 58, 103 (n), 112; Soul I (18x): 7, 13, 16 (d), 21, 23, 30, 55, 66, 92, 104 (d), 109, 113, 115, 126, 135, 153, 164; HomFr I 18; Dream (7x): 24, 45, 63, 102, 109-10, 131; El (84x): 17, 38, 41 (c), 62 [cr], 66 (n)8, 70-2, 74, 82, 101, 112, 124, 155, 191, 195, 213, 220, 235, 239-40, 244 [cr], 270, 276, 280 (r), 286, 293, 377 (c), 400, 403, 413, 423, 429, 431 (l), 433, 466, 471, 473, 475, 480, 516, 548 (b)-9, 560 [cr], 569, 576, 610, 632, 639 (c), 690 (c), 725, 737 (b), 739, 768 (b), 801 (st)-2 (r), 813, 847 (c)-8 [cr], 855, 863 (b), 876 (l)-7, 891, 901, 905, 1032, 1059 (n), 1142-3, 1155, 1170, 1179-80, 1188-90 (c), 1207 (l), 1228, 1265, 1290 (d), 1293; ChristA (18x): 20, 29 [cr], 43 (l), 105, 133 (r), 141, 148, 158 [cr], 199, 216 [cr], 228, 260 (n), 262, 280, 327, 336 (b) [cr], 377, 395; ChristB (22x): 441, 454, 465, 487, 510, 543, 575, 624, 658, 662, 695, 706, 714 (c), 730, 736, 757, 768 (b), 798, 800, 808 (r), 817, 857; ChristC (38x): 880 (b) [cr], 912 (l), 914, 920, 980, 984, 988, 1059, 1087 (sc), 1109, 1121, 1125 (b), 1191, 1202, 1204 (d), 1207, 1226, 1233, 1235, 1238 (b), 1249, 1328, 1338, 1406-7, 1450, 1452 (l), 1482, 1516, 1547, 1556, 1562, 1575, 1581, 1590, 1634 (b), 1641 (l), 1651 (l); GuthA (30x): 33, 60, 105, 112, 136, 233, 236, 269, 450-1, 454, 484 (l), 508, 564, 585, 593, 612 (l), 624, 626, 628, 666, 676, 697 (b), 704, 716, 719, 729, 736, 784, 816; GuthB (29x): 821 (c), 827, 832 (n), 856, 861-2 (d), 881, 891, 899, 946 (l), 973, 990 (d)-1, 1013 (b), 1022, 1024 (b), 1048, 1073, 1107, 1109, 1125, 1138 (d), 1171, 1215 (b), 1228, 1244, 1292, 1338, 1344; Az (8x): 22 (l)-3, 74, 98 (d), 104, 123 (d), 139, 161; Phoen (46x): 4, 25, 54, 65, 73, 85, 117, 125 (b), 131-2, 134, 142, 168, 171, 211, 223, 226 (b), 260, 271, 286, 289, 328, 341, 349, 368, 375, 389, 401 (b), 405, 416, 431 (n), 453 (d), 464, 467, 469, 478 (l), 506, 517 (l), 542, 549 (b), 558, 564, 603, 637 [cr], 645, 653; Jul (38x): 32, 37-8, 63, 91, 109, 129, 150, 173, 178 (l), 180, 199, 208, 227, 265 (b), 295, 308, 345-6, 354, 366, 391, 400, 453, 487, 508, 510 (b), 516, 555, 557, 573, 609, 625, 663, 665 (b), 671 (sc), 717, 720; Wan (7x): 14, 26, 28, 35, 66, 68, 105; Gifts (7x): 25, 44, 49, 63, 82, 87, 97; Prec (3x): 12 (l), 41, 56; Sea (7x): 20, 54 (b), 65 (l), 78, 86, 116, 123; Vain (6x): 15, 26, 28, 53, 59, 61 (p); Wid (5x): 29, 36, 104, 106, 116; Fort (7x): 5 (l), 8, 36, 41, 60, 62, 72; Max I (15x): 6, 38 (b), 51, 79, 81 (b), 88, 124-5, 127, 146, 149, 151, 164 [cr], 170, 181; OrW (11x): 25, 27, 41, 64 (b), 66-7, 70, 80 (b), 89, 99 (l), 101; Rim (8x): 6, 26 (sc)-7, 40 (l), 42, 53 (l), 64; Pan (6x): 3, 10, 16 [cr], 57, 61 (d), 72; Whale (9x): 17 (st)-19, 25, 37 (c), 39, 42, 61, 85; Soul II (11x): 7, 16 (d), 21, 27, 52, 61, 78, 98 (d), 104, 108, 110; Deor: 31; Wulf: 5; Rid 1-59 (61x): 3.8, 19, 25, 41, 51 (sc), 56, 62, 4.4, 9, 8.5 (b), 10.7, 13.10, 14.13, 15.8, 20.11, 16, 21.11, 22.5, 19, 23.9, 24.23, 26.23, 25, 29.2 (l), 30a.1, 3, 7, 31.20, 32.7, 11, 35.6, 36.9, 13, 38.6 (b), 39.28, 40.4, 14, 29, 37, 65, 79, 89, 106, 42.9 [cr], 44.5, 46.1, 47.5, 48.6 [cr], 50.2 (t), 51.3, 53.2, 11, 54.10, 56.4, 57.2, 58.2, 59.15, 17; Wife (4x): 22, 31, 39, 46; JDay I (11x): 1-2, 4 (b), 23, 72, 94 (c), 96 [cr], 99, 107, 114, 117 (l); ResA: 11; ResB (3x): 79, 88, 108; Hell (4x): 37 (b), 66, 71, 120; Rid 30b: 7; Husb (3x): 8 (c), 25, 29; Ruin (4x): 1 (b), 22, 26, 38; Rid 61-95 (15x): 62.4, 8, 66.5, 73.25, 74.4, 80.3, 6, 84.22, 26, 86.6, 88.12, 14-15, 23, 92.2; Вео (193x): 15 (l), 22, 36, 81, 88-9 [cr], 92, 136, 169, 178-9, 185, 207, 213 (b), 217, 228, 233, 248, 281 (c), 283 (b), 287 (sc)-8 [cr], 
316, 318, 332, 334, 345, 472, 476, 494, 497 (d), 503, 515, 533, 536-8, 568 (l), 570, 585, 603, 643, 674, 733, 740, 744, 752, 757, 772, 777, 792 (l), 813, 823, 835, 861, 890, 911, 924, 930, 942, 957, 960, 968, 970 (l), 992, 1012 (b), 1016 [cr], 1055, 1078, 1084 (p), 1110, 1117, 1129, 1131, 1135, 1177, 1197, 1255, 1276, 1298 (b), 1311, 1314-15 [cr], 1323, 1349, 1402, 1407, 1411, 1417, 1431, 1438 (n), 1454 [cr], 1465, 1508, 1521, 1541, 1572, 1581, 1614, 1617, 1626 (b), 1631, 1642, 1661, 1663, 1666 (b), 1674 (b), 1697, 1736, 1738, 1741, 1802 (sc)-3, 1822, 1832, 1837, 1875, 1898, 1905, 1908, 1928, 1949, 2072, 2096 (l), 2113, 2144 (l), 2150, 2152, 2155, 2174, 2178 (d), 2198, 2220, 2242 (n), 2258 (b), 2273, 2288, 2315, 2346, 2378, 2396 (n), 2398, 2433, 2447, 2452, 2462, 2516-17, 2550, 2555, 2568 (b)-9 (sc), 2583, 2588-9, 2612, 2614 (b), 2616, 2635, 2640, 2642, 2650, 2695 (c), 2699, 2703 (b)-4, 2719, 2749-50 (l), 2752, 2754 (b), 2765, 2821, 2860, 2862, 2871, 2886, 2928, 2969 (p), 2983, 2985, 3003, 3038, 3050, 3054, 3061, 3065 (b), 3077, 3082, 3098, 3101, 3123, 3139 (b), 3147 [cr]; Jud (24x): 14, 28 (d), 36, 38 (b), 66, 71, 89, 95, 137 (b) [cr], 155 [cr], 184, 211, 214, 235 [cr], 247 (b), 272-3, 280, 288, 290, 293, 296 (l), 310 (c) [cr], 330 (p); PPs (238x, excluding alliteration enjambed across psalm verses): 52.1.3, 53.7.1, 54.9.2, 16.1, 55.7.1, 10.1, 10.7 (l), 56.7.1, 9.2, 57.3.1, 4.4, 6.3, 9.1, 58.15.1, 59.5.1 [cr], 61.5.2 (b), 62.6.1, 9.1, 10.2, 63.2.1, 5.1, 6.1, 64.6.1, 8.1, 9.3, 11.2 (c), 65.2.1, 3.1, 3.3 (n), 4.2, 8.1 (l), 67.4.1 (n), 16.2, 21.1, 21.3 (sc), 68.3.3, 4.1, 9.1, 14.1, 24.1, 70.8.1, 16.3, 18.2, 22.2, 71.4.2 (b), 10.1, 72.24.1, 73.10.1, 11.1, 18.3, 74.8.2, 8.4, 75.8.1, 76.4.3, 7.2, 8.1, 14.1 (st), 77.10.4, 13.2, 19.1, 20.3, 46.1, 53.2, 62.1, 66.1, 69.1, 78.2.1, 79.4.1, 7.1, 13.1 [cr], 80.11.1, 81.1.1, 5.2, 8.1, 82.3.3, 4.3, 6.1, 7.1, 83.3.1, 6.3, 84.2.1, 9.2, 10.1, 86.2.1 (c), 88.3.3, 6.2, 15.1, 20.1, 32.4, 89.2.2, 8.1, 13.1, 16.1, 18.1, 91.8.2-3 [cr], 10.2, 92.8.1, 93.9.5 (b), 12.1, 18.2, 20.1, 94.1.2, 4.1, 95.12.2, 98.1.2, 100.2.1, 3.2, 4.3 (n), 7.1, 101.3.1, 12.3, 15.1, 22.2, 23.1 [cr], 24.1, 102.3.1, 5.1, 103.1.1, 9.1 (st), 14.2, 21.1, 104.5.1, 6.1, 10.1 (c), 15.3, 22.1, 23.1, 39.1, 105.2.3, 3.2, 6.1, 11.1 (l), 12.1, 17.1, 17.3, 20.2, 21.1, 25.5, 36.6, 106.17.1, 19.2, 107.4.1, 6.1 [cr], 108.6.1 [cr], 7.2, 14.3, 15.2, 18.1, 110.6.4, 8.1, 111.7.3, 113.16.1, 21.3-4 (b), 24.1, 114.4.1 (n), 117.13.1, 16.1, 118.2.1, 22.1, 40.1, 47.1, 58.2, 69.1, 72.2, 77.2, 91.1, 96.1, 104.2, 109.2, 126.2 [cr], 135.2, 138.3, 143.1 (n), 145.1, 168.3, 119.1.1 (c), 120.4.1, 121.5.1 (d) -2, 8.1 (n) -2 , 123.4.2, 124.2.1, 4.4, 125.1.2, 126.3.3, 127.4.1, 128.3 .3 (sc), 4.2, 129.2.1, 3.2, 131.10.2, 11.1, 133.2.2, 3.1, 135.1.2, 136.3.1, 4.1, 137.1.2, 1.5, 138.4.1, 5.1, 6.3, 12.2-3, 19.1, 21.3, 139.3.3, 9.1, 12.1 (d), 13.1 (n), 140.5.2 (l), 141.4.1, 8.1, 142.1.3, 4.4, 7.2-3, 8.1, 9.1, 143.3.2, 8.3, 144.8.1 (b), 13.2, 15.1, 19.5, 145.5.1, 6.2 (d), 8.3, 146.5.3, 12.1, 147.2.3, 3.2, 148.5.1, 13.2, 150.2.1; Met (116x): 1.15, 28, 32, 61, 69, 2.18, 4.3, 21, 33, 52, 54, 5.37, 6.8, 7.4, 20, 38, 8.19, 36, 9.15 (t), 20, 30, 35, 55, 61, 10.2, 5, 30, 40 (r), 56, 11.11, 27, 33, 40, 52 [cr], 58, 83, 12.5 (l), 8, 22-3 (c), 26, 13.53, 59, 14.7, 16.2, 7, 18.8 (l), 19.8, 11 (l), 20.6, 28 (p), 31, 39 (p), 52 [cr], 79, 82, 92, 105, 109, 123 [cr], 140, 146, 158, 190, 202, 209, 221, 227, 237, 252, 257, 275 [cr], 21.16, 22.3, 7-8, 10, 22, 26, 23.5, 24.4, 55, 25.8, 40, 51, 26.12, 39 (l), 100, 115, 27.15, 28.22-3, 31, 37, 50, 56, 58, 64, 67, 29.12, 26, 48-53 (48 (c), 50 (l)), 73, 75, 91-2, 30.7 (l), 10 (sc), 31.5 (c), 12; Finn (2x): 9, 22; Wald I: 5, Wald II (3x): 5, 13, 26; Mald (15x): 29, 82, 94, 117, 122, 125, 137, 173, 202, 213, 229, 257, 271, 280, 303; Brun (7x): 2, 11, 30, 37 (c), 43, 59, 61; CEdg: 14; DEdg (2x): 3, 11; DEdw (2x): 8, 10; Dur (3x): 3, 10 (c), 14 (b); MRune (6x): 2 (d), 17, 46 (b), 65 (b), 74, 85; MSol (23x): I. 25 (d), 34, 45, 51, 65, 67, 83, 141 (t), 155, II.198, 220, 231(t) -2, 245, 274, 306 (b), 313 (l), 320, 327 (l), 340 (sc), 356, 412, 494; Men (7x): 42, 49, 80, 115 (p), 141, 146, 186; Max II (4x): 7, 9, 16, 53; JDay II (20x): 6, 11, 15-16, 20, 31, 43, 77, 98-9, 108, 112, 114, 134, 151, 189, 202, 204, 213 (b), 240, 256, 297; Exhort (5x): 18, 40, 42-3 (d), 81 (l); Summons (3x): 6, 8, 21; LPr II (5x): 4, 16, 22, 35, 41; Glor I (4x): 18, 26 [cr], 35 [cr], 56 (c); $\operatorname{LPr} I I I$ (3x): 9, 12, 17 (c); Creed (4x): 22 (b), 26 (d), 50, 53 (l); PsFr (10x): 5.1.1, 19.9.1, 24.5.2, 34.3.3, 50.12.1, 64.6.1, 79.18.1, 89.18.1, 102.3.1, 5.1; KtHy (3x): 9, 13, 31; KtPs (7x): 6 (p), 69, 77, 89 (p), 116, 122 (b), 147; Pr (3x): 5, 54, 76; Thureth (2x): 8, 10; Aldhelm: 2; Seasons (11x): 2 (l), 41, 52, 56 (l), 102, 112, 144, 167, 190, 212, 227; BDS: 3; 
LRid: 6; CPEp (2x): 10, 22; GDPref: 7; MCharm (11x): 1.70, 3.11 (1), 8.5, 9.14, 11.4 (l), 6, 19, 22-3, 12.6, 9; Instr (13x): 11, 47, 57, 76, 119, 144, 159, 177, 180, 200, 212 (p), 228, 238.

By consonant where that sound occurs in less than $6 \%$ of the alliterations in the poetry in descending order of frequency (as listed in Table One) [e.gs in PPs within verses only]

b: GenA: 1602, 1812, 1821, 2931, GenB: 429, 478, Ex: 131, 477, Dan: 692, 698, Sat: 137, And: 183, 580, 646, 996, 1064, 1261, 1404, 1532, El: 863, ChristA: 336, ChristB: 768, ChristC: 880, 1125, 1238, GuthA: 697, GuthB: 1024, Phoen: 125, 226, 401, 549, Jul: 265, 665, Sea: 54, Max I: 38, 81, OrW: 64, 80, Rid 1-59: 8.5, 38.6, Hell: 37, Ruin: 1, Beo: 213, 1012, 1298, 1666, 2258, 2568, 2614, 2703, 2754, 3065, 3139, Jud: 38, 137, 247, PPs: 113.21.4, Dur: 14, MRune: 46, 65, MSol: II.306, JDay II: 213, Creed: 22, KtPs: 122

l: GenA: 210, 867, 944, 1145, 1179, 1195, 1409, 1670, GenB: 332, 434, 587, 623, Ex: 5, 43, 52, 194, 307, 383, Dan: 28, 301, 434, 451, Sat: 290, 298, 713, And: 867, 1422, 1478, El: 431, 876, 1207, ChristA: 43, ChristC: 912, 1452, 1641, 1651, GuthA: 484, 612, GuthB: 946, Az: 22, Phoen: 478, 517, Jul: 178, Prec: 12, Sea: 65, Fort: 5, OrW: 99, Rim: 40, 53, Rid 1-59: 29.2, JDay I: 117, Beo: 15, 568, 792, 970, 2096, 2144, 2750, Jud: 296, PPs: 55.10.7, 65.8.1, 105.11.1, 140.5.2, Met: 12.5, 18.8, 19.11, 26.39, 29.50, 30.7, MSol: II.313, 327, Exhort: 81, Creed: 53, Seasons: 2, 56, MCharm: 3.11, 11.4

d: GenA: 2081, 2324, 2670, GenB: 484, Ex: 40, 500, Dan: 21, 36, 476, Sat: 162, And: 1402, 1474, 1695, Soul I: 16, 104, El: 1290, ChristC: 1204, GuthB: 862, 990, 1138, Az: 98, 123, Phoen: 453, Pan: 61, Soul II: 16, 98, Beo: 497, 2178, Jud: 28, PPs: 121.5.1, 139.12.1, 145.6.2, MRune: 2, MSol: I.25, Exhort: 43, Creed: 26

c: GenA: 968, 1296, 1618, 2548, Ex: 229, 420, And: 827, 928, 1410, El: 41, 377, 639, 690, 847, 1190, ChristB: 714, GuthB: 821, Whale: 37, JDay I: 94, Husb: 8, Beo: 281, 2695, Jud: 310, PPs: 64.11.2, 86.2.1, 104.10.1, 119.1.1, Met: 12.23, 29.48, 31.5, Brun: 37, Dur: 10, Glor I: 56, LPr III: 17

p: GenA: 75, 1964, 2212, GenB: 408, 640, Sat: 577, And: 1135, El: 548, 737, 768, GuthB: 1013, 1215, Jul: 510, Vain: 61, JDay I: 4, Beo: 283, 1084, 1626, 1674, 2969, Jud: 330, PPs: 61.5.2, 71.4.2, 93.9.5, 144.8.1, Met: 20.28, 20.39, Men: 115, KtPs: 6, 89, Instr: 212

r: GenA: 2030, 2191, Ex: 295, And: 133, El: 280, 802, ChristA: 133, ChristB: 808, Met: 10.40,

n: GenA: 888, And: 833, Fates: 103, El: 66, 1059, ChristA: 260, GuthB: 832, Phoen: 431, Beo: 1438, 2242, 2396, PPs: 65.3.3, 67.4.1, 100.4.3, 114.4.1, 118.143.1, 121.8.1, 139.13.1,

t: GenB: 540, Sat: 707, Rid 1-59: 50.2, Met: 9.15, MSol: I.141, II.231

st: GenA: 1375, And: 737, 1335, El: 801, Whale: 17, PPs: 76.14.1, 103.9.1,

sc: GenA: 136, ChristC: 1087, Jul: 671, Rim: 26, Rid 1-59: 3.51, Beo: 287, 1802, 2569, PPs: 67.21.3, 128.3.3, Met: 30.10, MSol: II.340

sp:

p:

Total: 1750 instances 


\section{Appendix Five: Crossed Alliteration}

In brackets is indicated the alliterating sound of the $\mathbf{B}$ (or extra) alliteration where that sound occurs in less than $6 \%$ of the alliterations in the poetry (as listed in Table One].

a) on syllables bearing full stress (in Bliss’s system of scansion)

(i) in normal verses $(\mathrm{AB} A B)$ :

GenA (50x): 5, 41, 100, 113, 225, 909, 990, 1010 (p), 1093, 1162, 1251, 1257 (b)-8 (n), 1262, 1291, 1298, 1307, 1331, 1346, 1350, 1354 (b), 1413, 1445, 1456, 1696 (sp), 1740, 1914, 1925, 2008, 2073, 2097, 2282, 2294, 2345, 2454, 2491, 2508, 2511 (p), 2549, 2633 (d), 2668, 2698, 2701, 2710 (c), 2775 (b), 2787, 2808, 2833, 2879, 2905; GenB (8x): 245, 277, 465, 554, 582, 646 (b), 686 (b), 844; Ex (5x): 38 (fr: f), 326, 412, 514, 523; Dan (13x): 9, 63, 75 (p), 176, 333, 578, 613, 635, 651, 696 (n), 702, 726, 735 (c); Sat (10x): 57, 76, 106, 218, 417 (sc), 432 (p), 615, 688, 695, 709; And (14x): 131, 517, 631 (c), 637, 691, 807, 854, 969, 1049, 1152, 1223, 1363, 1416, 1619; Soul I: 5; Dream: 108; El (20x): 5, 95, 178, 227 (st), 250 (l), 283, 372, 374 (c), 445, 492, 497 (l), 717-18, 913, 1066, 1259, 1277, 1280, 1284, 1314; ChristA (7x): 16, 29, 100, 158, 216, 230, 431; ChristB (2x): 467, 832 (c); ChristC (9x): 868 (d), 1063 (b), 1089 (b), 1126 (b), 1158 (b), 1161, 1320 (b), 1404, 1577; GuthA (10x): 29 (c), 126 (l), 326, 408 (p), 422, 520 (l), 524 (d), 598 (c), 746, 780; GuthB (10x): 819 (c), 842, 879, 896 (b), 936, 992 (t), 1061, 1136 (b), 1264, 1267; Az (2x): 49, 125; Phoen (8x): 91 (c), 235 (b), 292, 374, 411, 422, 450 (t), 637; Jul (7x): 121, 254, 323, 396, 530, 647, 658; Wan (3x): 31, 108-9 (l); Prec (2x): 55, 58; Sea: 111; Vain (2x): 29, 69; Wid: 44; Max I: 108 (c); OrW: 33; Pan: 16; Whale (2x): 43, 74; Soul II: 5; Rid 1-59 (19x): 9.12 (d), 10.6 (c), 16.4, 10, 17.2, 26.1, 18, 27.4 (l), 28.5, 39.1, 40.34, 90, 42.8-9, 44.5, 47.3, 48.6, 51.5, 54.9, 55.9; Hell: 127; LPr I 4; Ruin: 43 (st); Rid 61-95 (5x): 61.3, 65.5 (b), 76.1, 84.29, 88.24 (sc); Вeo (35x): 19, 34 (p), 88, 98, 201 (p), 365, 374, 418 (c), 525 (b), 589 (d), 591, 653 (b), 699 (c), 730, 803.829 (l), 907, 1182, 1203, 1341, 1475, 1488 
(l), 1611, 1824 (d), 1849, 1968, 2091, 2170, 2186-7, 2397, 2567 (b), 2745 (l), 2875, 3162; Jud (8x): 78, 83, 85 (p), 137 (b), 155, 235, 253, 310 (c); PPs (94x): 51.6.4, 52.4.3, 53.3.3, 5.2, 55.9.3 (d), 59.5.1, 60.3.3 (b), 5.2, 61.7.2, 62.2 .1 (b), 8.1 (b), 63.3.3 (b), 5.1, 65.1.3, 9.2 (d), 13.4, 68.18.2, 70.5.3 (n), 72.8.1, 24.2 (d), 74.3.1, 76.9.5, 11.2, 77.9.1, 22.2, 38.2, 42.1, 67.2 (c), 78.9.1, 79.13.1, 80.12.1, 82.4.4 (n), 10.2, 83.10.2, 84.8.2, 86.1.2 (d), 87.4.1, 9.4 (b), 18.2, 89.6.1, 90.6.3 (d), 93.9.3, 18.1, 94.1.1, 10.3 (c), 98.3.2, 100.1.1, 101.23.1, 102.7.3, 103.11.1 (d), 25.1 (p), 33.2, 104.27.1 (c), 30.1 (c), 105.13.1, 15.2, 31.3, 106.11.1, 28.4, 107.6.1, 10.1, 108.6.1, 111.8.4, 113.13.1, 117.19.2, 118.37.1, 59.1 (b), 112.2, 126.2, 160.4, 164.4, 119.3.1, 5.3 (n), 6.2, 120.4.3, 122.4.2, 124.5.1 (b), 5.4, 126.4 .3 (b), 128.3.1, 3.5, 131.1.1, 133.2.3, 134.14.1 (d), 135.27.2, 137.6.1, 8.3, 138.18.2 (n)-3 (b), 142.6.1 (b), 144.20.2, 145.7.2 (b), 8.4, 148.4.2, 149.1.2; Met (32x): 1.16, 38, 4.45, 5.13, 7.40 (l), 8.14, 43, 10.37 (l), 11.20, 52, 57(?), 70, 13.10, 43, 79 (d)-80, 16.8, 20.10, 52-3 (sc), 110, 114, 123, 275, 21.38, 22.62, 23.2, 25.29 (b), 26.19 (c), 33, 29.4 (t), 70, 30.15; Finn (2x): 12, 23; Mald (8x): 68 (st), 98, 130, 170, 255 (c)-6 (c), 285, 320 (b); Brun: 33; CEdg: 1; DEdw: 10; MRune: 92 (c); MSol (3x): II.223 (sc), 263, 265; Men (5x): 9, 65, 81, 194 (n), 203 (n); Max II: 50; JDay II (8x): 88, 102, 155 (b), 158 (c), 160 (b), 166, 279 (b), 286; Exhort (3x): 7, 19 (l), 65; LPr II (2x): 40, 110; Glor I (2x): 26, 35; Creed: 19 (b); PsFr 43.27 .1 (d), 50.1 .1 (d); KtHy: 22 (l); KtPs (4x): 1, 48, 61, 66; Thureth: 5; Seasons (3x): 9, 169 (d), 192; BDS (WS): 2; MEp 2; MCharm (15x): 1.27 (d), 2.14, 45-51, 4.20 (sc), 23 (sc), 25 (sc; double crossed), 9.8; Instr (8x): 33, 39 (l), 54, 110, 143 (l), 168 (b), 188, 223.

(ii) in hypermetric verses:

$(\mathrm{AB} A B)$

OrW: 98; LPr I: 4; MCharm: 3.12 (c)

$(\mathrm{AAB} A B)$

GenA (4x): 913, 1015, 2407 (sp), 2859 (b); GenB (3x): 342, 389, 507; Dan: 203; Dream (3x): 23, 49, 65; ChristC: 889; GuthA (3x): 3 (d), 5, 239 (b); Wan: 113 (c); Max I (3x): 41, 144, 164; Beo: 1705; Jud (4x): 3 (p), 20, 58, 339; MRune: 27 (n); MSol (2x): II.339, 458.

(Other alliterative patterns)

GenA: 2867; Max I (2x): 59, 114; MSol (2x): II.312, 329 (d); ${ }^{417}$ Max II: 42; MCharm: 4.25.

\section{b) where one of the syllables in the crossed alliteration bears secondary stress in a light verse}

(i) the light verse is in the a-verse (Ab $A B)$ :

GenA (14x): 201, 881 (b), 1118 (st), 1221 (d), 1560 (b), 1846, 1917, 1954, 2241, 2321 (c), 2492, 2548 (c), 2608, 2704; GenB: 829 (sc); Ex (4x): 124, 208, 323, 350; Dan: 534; And (6x): 418 (c), 554, 965 (c), 1066, 1577, 1580 (r); Dream (2x): 91, 126; El (7x): 63, 98, 247, 809, 848, 868 (b), 914; ChristA (2x): 246 (c), 250 (c); ChristB (5x): 450 (c), 460, 531, 787, 820; ChristC (5x): 1314, 1450, 1486, 1500 (r), 1611; GuthA (3x): 198 (c), 389, 781; GuthB (5x): 827, 877, 987, 1090, 1193; Phoen (2x): 5, 87; Jul (4x): 68, 384 (p), 578, 684 (sc); Sea (2x): 52, 57 (l); Vain (2x): 12 (r), 78; Pan 45 (st); Rid 1-59 (4x): 15.10 (c), 14, 20.31 (st), 31.9; Wife: 48; JDay I: 96; ResB: 87; Husb (2x): 12, 20 (b); Ruin: 27; Rid 61-95: 80.4; Beo (37x): 282, 343 (b), 397 (b), 566 (l), 919, 971, 1016, 1140, 1201 (r), 1262 (b), 1301, 1314, 1342, 1403, 1443

${ }^{417}$ See Bliss, Metre, p. 96, on MSol II.329; crossed alliteration appears to have replaced the normal alliterative pattern. 
(b), 1445 (c), 1799, 1937, 1939, 1995, 2030, 2066, 2162, 2181 (c), 2223, 2235, 2261, 2267, 2465 (b), 2479, 2515, 2593, 2726, 2954, 2970 (c), 2998, 3074, 3147, 3153 (d); Jud (2x): 173, 215 (b); PPs (14x): 56.12.1, 58.9.2, 18.1, 68.30.2, 73.7.3 (d)-4, 75.3.1 (b), 76.2.1 (d), 77.37.2 (d), 58.3, 91.8.2, 93.3.1, 19.2 (st), 125.4.2; Met (8x): 8.31, 9.47 (c), 11.28 (l), 75 (l), 17.21, 20.6, 22.25, 29; Wald I: 17; Mald (2x): 24, 63 (st); Brun (3x): 14 (t), 48, 50; MRune: 40; JDay II: 117 (b); Creed: 16 (c); KtPs (3x): 14, 19 (d), 143; BDS (Nmb): 2, GDPref: 23.

(ii) the light verse is in the b-verse $(\mathrm{AB} A \mathrm{Ab})$ :

GenA (3x): 1114, 1638, 2602; And (2x): 94 (p), 417, El (2x): 335, 1178; ChristB: 766 (sc); ChristC: 1436; GuthA: 599; GuthB: 1151 (d); Phoen: 623; OrW: 60; Pan: 47 (bl), Wife: 42; Beo (2x): 32 (st), 209; Jud: 165; Met (2x): 3.5 (l), 8.52.

(iii) there is a light verse in both verses ( $\mathrm{Ab} A b)$ :

GenA: 2003; And: 1447 (c); El (2x): 146, 844; Gifts: 10; Beo (3x): 1 (d), 39, 1910 (st); MCharm (3x): 2.52-4 (all b).

\section{c) where one of the syllables in the crossed alliteration bears secondary stress either in a normal verse with a compound, or in a heavy verse, or a hypermetric verse}

(i) the normal verse with a compound or heavy verse is in the a-verse (AAb $A B)$ :

GenA (5x): 917 (sc), 943, 1773, 1797 (c), 2098 (l); GenB (3x): 303, 582, 718; Ex: (2x) 253, 515; Dan: 214; And (11x): 38, 330, 524, 568, 662, 912, 982, 1297, 1513, 1638, 1690; El (8x): 21, 62, 94, 123, 647, 841, 1029, 1316; ChristA (4x): 20, 118 (sc), 173, 424; ChristB (11x): 465, 504, 507 (b), 532, 546, 605 (l), 660, 703, 769 (l), 774, 860; ${ }^{418}$ ChristC (6x): 880 (b), 998, 1070, 1104, 1642, 1647; GuthA: 257; GuthB (4x): 1078, 1116 (t), 1239, 1345; Phoen (4x): 329 (c), 397, 409, 675; Jul (7x): 16 (c), 104 (l), 473, 503, 563, 615, 699 (l); Wan: 47; Gifts: 84; Prec: 53; Fort: 39 (sc); Pan: 58; Whale: 2 (c); Rid 1-59: 20.4; ResB: 97 (sp); Hell: 21; Ruin: 27 (st); Beo (20x): 33, 65, 288, 305, 614, 755, 938, 1023, 1161-2, 1200; 1400, 1454, 1460, 1702, 2300, 2731, 2819, 3084 (sc), 3105; Jud (3x): 223, 237 (b), 325 (l); PPs: 74.7.3; Met (3x): 6.2 (cw), 8.3 (cw), 20.10; Finn (2x): 6, 38 (b); Mald (2x): 102, 262 (b); Brun: 6 (l); MRune: 36; Max II: 19, 27; JDay II (2x): 146 (l), 300; KtHy: 30, Instr: 220.

(AbA AB):

GenA (2x): 1021 (l), 1796; And (4x): 804, 1059, 1117, 1415; El (2x): 112, 1035; ChristB: 682 (b); ChristC: 942 (c); GuthB (6x): 956, 1029, ${ }^{419}$ 1073, 1164, 1315 (1), 1326; Phoen (2x): 152 (b), 462; Sea: 12; Vain: 51; Rim (2x): 65, 68; Whale: 29; ResA: 66; Beo (13x): 93, 208, 490, 1065, 1128, 1243, 1311, 1650, 1852, 2108, 2317, 2987, 3149; PPs: 118.136.2.

$(\mathrm{AbC} A B)$

GenA (8x): 1321, 1484 (r), 1683, 1695 (b), 1711, 1728 (b), 2335, 2772; Ex: 352 (b); ChristB (2x): 528, 636 (n); ChristC: 1556; Alms: 2; Beo (2x): 2588, 3165; PPs: 81.1.1; MEp: 2 (r).

(Other alliterative patterns):

And: 1603; ChristA: 336; Max II: 46.

(ii) in a hypermetric a-verse (AAb AB, AAbC Ab, AbAC Ab):

${ }^{418}$ ChristB 660 and 860 are identical lines.

${ }^{419}$ GuthB 956 and 1029 are near verbatim repeats. 
Sea: 23 (c); Jud (2x): 20, 344 (l).

(iii) the normal verse with a compound or heavy verse is in the b-verse (various patterns):

Ex (3x): 60, 173 (b), 551 (st); ChristB: 618; Prec: 76; Max I: 8; Hell: 50; Beo (3x): 1494, 2100, 2282; PPs: 119.5.2; MSol: II.262; Creed: 18; MCharm: 7.8.

d) where one of the syllables in the crossed alliteration bears secondary stress in a light verse and another bears secondary stress either in a normal verse with a compound or a heavy verse

(i) the light verse is in the a-verse (Ab $\mathrm{AbC})$ :

GenA: 2051; Beo: 1131; Gifts: 50 (b).

(ii) the light verse is in the b-verse (AAb $\mathrm{Ab})$ :

GenA: 929; Sat: 454; And (2x): 31, 1630; El: 560; ChristB: 769 (l); ChristC: 998; Gifts: 84; Beo: 1594.

(Other alliterative patterns):

ChristA: 367 (c); GuthB: 1378; Gifts: 77.

e) where both of the syllables in the crossed alliteration bear secondary stress either in heavy verses, or in normal verses with a compound, or in one of each

El: 244; Rid: 33.6; Ruin: 38; Beo (3x): 131, 236, 690 (r); MSol: II.180; KtPs: 10; MCharm: 11.6 .

f) where one of the syllables in the crossed alliteration bears secondary stress in a defective verse

Rid: 72.12; Beo: 2231

g) with double crossed alliteration

PPs: 111.5.1 [AbAc ABc]

By consonant where that sound occurs in less than $6 \%$ of the alliterations in the poetry in descending order of frequency (as listed in Table One)

b: GenA: 881, 1257, 1354, 1560, 1695, 1728, 2775, 2859, GenB: 646, 686, Ex: 352, ChristB: 507, 682 ChristC: 880, 1089, 1158, GuthB: 1136, Phoen: 152, 235, Gifts: 50, Pan: 47, Rid 6195: 65.5, Вeo: 93, 343, 397, 653, 1262, 1443, 2465, 2567, Jud: 137, PPs: 75.3.1, 124.5.1, 126.4.3, 138.18.3, 145.7.2, Met: 25.29, Finn: 38, Mald: 262, 320, JDay II: 117, 155, 160, 279, Creed: 19, MCharm: 2.52-4

I: GenA: 1021, 2098, El: 250, 497, ChristB: 605, 769, GuthA: 126, 520, GuthB: 1315, ChristB: 769, Jul: 104, 699, Wan: 109, Sea: 57, Rid 1-59: 27.4, Beo: 566, 829, 1488, 2745, Jud: 325, 344, Met: 3.5, 7.40, 10.37, 11.28, 11.75, Brun: 6, JDay II: 146, Exhort: 19, Instr: 39, 143

d: GenA: 1221, 2633, ChristC: 868, GuthA: 3, 524, GuthB: 1151, Rid: 9.12, Beo: 1, 589, 1824, 3153, PPs: 55.9.3, 65.9.2, 72.24.2, 73.7.3, 76.2.1, 77.37.2, 86.1.2, 90.6.3, 103.11.1, 134.14.1, Met: 13.79, MSol: II.329, PsFr: 43.27.1, 50.1.1, KtHy: 22, KtPs: 19, Seasons: 169, MCharm: 1.27 
c: GenA: 1797, 2321, 2548, 2710, And: 418, 631, 965, 1447, El: 374, ChristA: 246, 250, 367, ChristB: 450, 832, ChristC: 942, GuthA: 29, 198, 598, GuthB: 819, Phoen: 91, 329, Jul: 16, Wan: 113, Sea: 23, Max I: 108, Whale: 2, Rid 1-59: 10.6, 15.10, Beo: 418, 699, 1445, 2181, 2970, Jud: 310, PPs: 77.67.2, 94.10.3, 104.27.1, 104.30.1, Met: 6.2, 8.3, 9.47, 26.19, Mald: 255-6, MRune: 92, JDay II: 158, Creed: 16, MCharm: 3.12

p: GenA: 1010, 2511, Ex: 173, Dan: 75, Sat: 432, And: 94, El: 868, ChristC: 1063, 1126, 1320, GuthA: 239, 408, GuthB: 896, Jul: 384, Husb: 20, Beo: 34, 201, 525, Jud: 3, 85, 215, 237, PPs: 60.3.3, 62.2.1, 62.8.1, 63.3.3, 87.9.4, 103.25.1, 118.59.1, 142.6.1, Instr: 168

r: GenA: 1484, And: 1580, ChristC: 1500, Vain: 12, Beo: 690, MEp: 2

n: GenA: 1258, Dan: 696, ChristB: 636, PPs: 70.5.3, 82.4.4, 119.5.3, 138.18.2, MRune: 27, Men: 194, 203

t: GuthB: 992, 1116, Phoen: 450, Beo: 1201, Met: 29.4, Brun: 14

st: GenA: 1118, Ex: 551, El: 227, Pan: 45, Rid 1-59: 20.31, Ruin: 27, 43, Beo: 32, 1910, PPs: 93.19.2, Mald: 63, 68

sc: GenA: 917, GenB: 829, Sat: 417, ChristA: 118, ChristB: 766, Jul: 684, Fort: 39, Rid 61-95: 88.24, Beo: 3084, Met: 20.53, MSol: II.223, MCharm: 4.20, 4.23, 4.25

sp: GenA: 1696, 2407, ResB: 97

\section{Appendix Six: Rates of Occurrence of Extra Alliteration}

The columns indicate the following in each poem over 70 lines in length

1: Numbers of lines in each poem

2: \% of lines with cluster alliteration

3: \% of lines involved in continued consonant alliteration

4: \% of lines involved in continued vowel alliteration

5: \% of lines in which the final stress participates in enjambed alliteration

6: \% of lines displaying crossed alliteration (all varieties), followed in brackets by the total number of lines)

7: Aggregate of columns 2-6 as a guide to overall intensity of the use of extra alliteration

\begin{tabular}{lcllllll} 
Poem & 1 & 2 & 3 & 4 & \multicolumn{1}{l}{5} & 6 & 7 \\
GenA & 2319 & 4.6 & 5.0 & 4.4 & 6.6 & $4.2(97)$ & 24.8 \\
GenB & 617 & 2.1 & 3.6 & 2.3 & 7.5 & $2.4(15)$ & 17.9 \\
Ex & 590 & 2.0 & 2.7 & 1.9 & 7.1 & $2.4(14)$ & 16.1 \\
Dan & 764 & 2.7 & 3.7 & 2.1 & 5.5 & $2.1(16)$ & 16.1 \\
Sat & 729 & 2.2 & 5.1 & 6.6 & 7.3 & $1.5(11)$ & 22.7 \\
And & 1722 & 3.4 & 4.6 & 2.5 & 6.4 & $2.4(41)$ & 19.3 \\
Fates & 122 & 3.3 & 6.6 & 4.9 & 3.3 & $0.0(0)$ & 18.1 \\
Soul I & 166 & 1.2 & 4.2 & 1.2 & 10.8 & $0.6(1)$ & 18.0 \\
Dream & 156 & 4.5 & 3.8 & 0.0 & 4.5 & $3.8(6)$ & 16.6 \\
El & 1321 & 3.0 & 5.3 & 2.4 & 6.4 & $3.3(43)$ & 20.4 \\
ChristA & 439 & 2.7 & 7.3 & 1.8 & 4.1 & $3.4(15)$ & 19.3 \\
ChristB & 427 & 3.7 & 6.6 & 1.9 & 5.2 & $5.6(24)$ & 23.0 \\
ChristC & 798 & 3.8 & 7.5 & 4.6 & 4.8 & $3.1(25)$ & 23.8 \\
GuthA & 818 & 3.7 & 3.2 & 1.0 & 3.7 & $2.2(18)$ & 13.8
\end{tabular}




$\begin{array}{lrrrrrlr}\text { GuthB } & 561 & 4.5 & 5.3 & 2.5 & 5.2 & 4.8(27) & 22.3 \\ \text { Az } & 191 & 7.8 & 0.5 & 1.0 & 4.2 & 1.0(2) & 14.5 \\ \text { Phoen } & 677 & 5.9 & 6.8 & 1.8 & 6.8 & 2.5(17) & 23.8 \\ \text { Jul } & 731 & 3.4 & 10.1 & 2.6 & 5.2 & 2.5(18) & 23.8 \\ \text { Wan } & 115 & 7.0 & 5.2 & 1.7 & 6.1 & 4.3(5) & 24.3 \\ \text { Gifts } & 113 & 0.0 & 3.5 & 0.0 & 6.2 & 4.4(5) & 14.1 \\ \text { Prec } & 94 & 3.2 & 2.1 & 2.1 & 3.2 & 3.2(3) & 13.8 \\ \text { Sea } & 124 & 5.6 & 8.1 & 1.6 & 5.6 & 4.0(5) & 24.9 \\ \text { Vain } & 84 & 3.6 & 2.4 & 4.8 & 7.1 & 6.0(5) & 23.9 \\ \text { Wid } & 143 & 3.5 & 8.4 & 6.3 & 3.5 & 0.7(1) & 22.4 \\ \text { Fort } & 98 & 5.1 & 4.1 & 4.1 & 7.1 & 1.0(1) & 21.4 \\ \text { Max I } & 204 & 4.9 & 3.9 & 1.0 & 7.4 & 2.0(4) & 19.2 \\ \text { OrW } & 102 & 4.9 & 9.8 & 0.0 & 10.8 & 2.9(3) & 28.4 \\ \text { Rim } & 87 & 25.3 & 2.3 & 0.0 & 9.2 & 0.0(0) & 36.8 \\ \text { Pan } & 74 & 6.8 & 2.7 & 5.4 & 8.1 & 5.4(4) & 28.2 \\ \text { Whale } & 88 & 4.5 & 9.1 & 0.0 & 10.2 & 4.5(4) & 28.3 \\ \text { Soul II } & 121 & 0.8 & 3.3 & 5.0 & 9.1 & 0.8(1) & 19.0 \\ \text { Rid 3 } & 74 & 12.2 & 2.7 & 2.7 & 9.5 & 0.0(0) & 27.1 \\ \text { Rid 40 } & 108 & 4.6 & 10.2 & 0.0 & 7.4 & 1.9(2) & 24.1 \\ \text { JDay I } & 119 & 4.2 & 1.7 & 0.0 & 9.2 & 0.8(1) & 15.9 \\ \text { Hell } & 137 & 0.7 & 5.8 & 0.0 & 2.9 & 2.2(3) & 11.6 \\ \text { Beo } & 3182 & 3.6 & 3.1 & 0.8 & 6.1 & 3.8(122) & 17.4 \\ \text { Jud } & 349 & 6.9 & 9.2 & 3.4 & 6.9 & 5.4(19) & 31.8 \\ \text { PPs } & 5039 & 1.8 & 5.4 / 9.6 & 3.8 / 7.4 & 4.7 & 2.2(112) & 17.9 / 25.7 \\ \text { Met } & 1740 & 2.1 & 4.6 & 11.0 & 6.7 & 2.6(45) & 27.0 \\ \text { Mald } & 325 & 4.6 & 8.3 & 4.6 & 4.6 & 3.7(12) & 25.8 \\ \text { Brun } & 73 & 5.5 & 5.5 & 2.7 & 9.6 & 6.8(5) & 30.1 \\ \text { MRune } & 94 & 7.4 & 0.0 & 2.1 & 6.4 & 4.3(4) & 20.2 \\ \text { MSol } & 506 & 5.1 & 6.5 & 2.2 & 4.5 & 1.6(8) & 19.9 \\ \text { Men } & 231 & 3.0 & 2.6 & 0.0 & 3.0 & 2.2(5) & 10.8 \\ \text { JDay II } & 306 & 4.6 & 3.6 & 5.6 & 6.5 & 3.6(11) & 23.9 \\ \text { Exhort } & 82 & 0.0 & 0.0 & 6.1 & 6.1 & 3.7(3) & 15.9 \\ \text { LPr II } & 123 & 0.0 & 3.3 & 3.3 & 4.1 & 1.6(2) & 12.3 \\ \text { PsFr } & 129 & 1.6 & 4.7 & 0.0 & 7.8 & 1.6(2) & 15.7 \\ \text { KtPs } & 157 & 0.6 & 7.6 & 2.5 & 4.5 & 4.5(7) & 19.7 \\ \text { Pr } & 79 & 0.0 & 2.5 & 7.6 & 3.8 & 0.0(0) & 14.9 \\ \text { Seasons } & 230 & 0.9 & 4.3 & 0.0 & 4.8 & 1.3(3) & 11.3 \\ \text { Instr } & 264 & 0.4 & 3.8 & 7.2 & 4.9 & 3.4(9) & 19.7\end{array}$

